Doctorado en Artes, Facultad de Artes,

Universidad Nacional de La Plata

\title{
SIMBOLIZAR LA NACIÓN
}

\author{
IMÁG ENES IDENTITARIAS \\ EN LAS PROPUESTAS ARTÍSTICAS \\ DEL KIRGHNERISMO
}




\section{Í N D I C E}

Agradecimientos | p. 4

Apostilla en primera persona $\mid$ p. 8

Introducción | p. 13

1 .

LOS MARCOS | p. 22

De qué hablamos cuando hablamos de

nación | p. 24

imagen, símbolo, metáfora, forma, desvío | p. 28

2.

EL ACCESO A LA FORMA | p. 34

Herencias | p. 36

La batalla | p. 43

Hilos | p. 59

3.

SINOPSIS DE UN FESTEJO | p. 61

Elogio de la multitud | p. 63

Oíd el ruido | p. 67

Diez minutos, treinta y tres segundos | p. 72

Alta en el cielo | p. 80

Lejanía | p. 88

4.

MEMORIA Y ASOMBRO | p. 89

Imágenes de una excursión | p. 93

Corrupciones | p. 99

Malvinas, la nación imaginada | p. 104

Volver al futuro | p. 112

5 .

LOS QUE HICIERON LA PATRIA. FICCIONES ACERCA DEL ORIGEN | p. 114 La fragilidad de los héroes | p. 118

Fronteras | p. 122

El sueño y el olvido | p. 127

Conclusiones | p. 132

Referencias | p. 140 
A Tita, Leli, Nano y Pocho, las fuentes. 
AGRADECIMIENTOS 
Los agradecimientos se leen al principio pero se escriben al final. En las tesis, como en el arte, es posible reconciliar tiempos. Este trabajo es el resultado momentáneo de un camino que se inició allá por los noventa en la guardería de la Universidad Nacional de La Plata y que se extiende hacia el futuro en la convicción de permanecer siempre en ese espacio inagotable que es la educación pública. Vengan entonces, primeras y últimas, las gracias.

A la Escuela Provincial Municipal $N^{\circ} 2$ de Barrio Jardín, en la que aprendí a leer y a cantar; al Bachillerato de Bellas Artes, sede de mi formación artística durante el secundario; a la Facultad de Humanidades y Ciencias de la Educación (UNLP), donde me recibí de Licenciada en Sociología y di los primeros pasos en la investigación; y a la Facultad de Artes (UNLP), querida casa en la que tengo el honor de trabajar y de seguir estudiando.

A quienes hacen posible que exista un Doctorado en Artes con perspectiva latinoamericana y con una oferta académica atenta a las transformaciones de la producción teórica y artística de nuestra región. En ese sentido, agradezco por partida doble a Eduardo Russo, director del posgrado y de esta tesis, por su disposición, sus comentarios agudos, su humor y su generosidad.

Al Consejo Nacional de Investigaciones Científicas y Técnicas (CONICET) por permitirme migrar el plan de trabajo de mi beca doctoral a esta Facultad, dando cuenta de una paulatina apertura al desarrollo de los estudios en arte, que durante mucho tiempo subsistieron en los márgenes del circuito de financiamiento académico y que aún tienen mucho terreno por ganar. Particularmente, gracias a Paula González, quien ejerció como directora de la beca sorteando las dificultades de la distancia física para acompañar el proceso, y a Aníbal Viguera por sus consejos y sus aportes determinantes en las instancias iniciales de este trayecto doctoral.

A mi papá, Daniel, el lector más interesado por mis escritos desde la escuela primaria, y a mi mamá, Diana, la espectadora fiel de cada producción en la que me embarco. Gracias a los dos por acercarme al arte y a la tarea docente desde muy chica, de ellos aprendí lo más importante que sé. 
A Graciana Pérez Lus y a Leopoldo Dameno, por las oportunidades cada vez más desafiantes, por sus pedagogías amorosas, por la confianza.

A Emmanuel Kahan, referente y amigo que, como director de mi tesis de grado, puso a disposición toda su experiencia para ayudarme a comprender «los gajes del oficio», además de abrir puertas y formular preguntas clave en cada etapa posterior.

A Mario Oporto, porque escuchándolo se activó el interés por la idea de nación y sus formas.

A Mora González Canosa y a Lucía Wood, profesoras de dos talleres metodológicos que fueron centrales, en momentos distantes, para dar un cauce más certero a mis voluntades ambiguas de doctoranda inexperta.

A Mariel Ciafardo, querida Mari, por aproximarme a interpretaciones y a categorías sustanciales del lenguaje visual con su claridad y su entusiasmo docente.

A Marta Zátonyi. Agradezco haber podido presenciar sus clases.

A las y los integrantes de los proyectos Memoria y Violencia en el siglo XX y La historia reciente y los usos públicos del pasado, radicados en el Instituto de Investigaciones en Humanidades y Ciencias Sociales (IdIHCS; CONICET-UNLP) por permitirme formar parte, como investigadora en formación, de los debates, las lecturas y las producciones teóricas que se gestaron ahí. Especialmente a Laura Amorebieta y Vera, en este punto en calidad de colega admirada, porque su estudio sobre las conmemoraciones bicentenarias en un conjunto de países de América Latina fue un insumo clave para definir el recorte temporal de los materiales que me interesaba vincular.

A quienes impulsan el proyecto Voces, ideas y relatos acerca de la enseñanza y el aprendizaje del arte en las escuelas (PIBA; FdA-UNLP), celebro poder colaborar en el primer programa de investigación en arte de la Universidad Nacional de La Plata.

A los equipos del Programa Derechos Humanos y Educación de la DGCyE, de la cátedra Historia Social General B, de la revista cultural y política Las Patas en la 
fuente, de la editorial Papel Cosido y de la Secretaría de Asuntos Académicos de la Facultad de Artes (FdA), espacios que transité a lo largo de estos años y donde surgieron muchas de las inquietudes que guiaron los análisis plasmados en este escrito. En particular, a Flor Mendoza, por compartir su sospecha hacia los gerundios con la misma pasión que el gusto por los señaladores autoadhesivos en las tardes de trabajo editorial.

A mis compañeras y compañeros de Fundamentos Psicopedagógicos de la Educación, por las discusiones, los intercambios, el respaldo. Y especialmente a las y los estudiantes de esas cursadas, por ser el estímulo que le da un sentido real al esfuerzo de seguir formándonos.

A mi familia, ese cúmulo extraño de gente reunida por el querer. Gracias por estar siempre en lo importante.

A mi hermana An, porque entre muchas otras cosas me enseñó a trabajar.

A las amigas y los amigos, que son la vida. A las intensas, a lxs sures, al Barco. A Loli y a Lau, por el entendimiento hondo que nos sostiene. A Jose y a Majo, hermanas de la música, por haberme dado un lugar desde el cual seguir empujando los límites del hacer artístico.

Y último pero sobre todo, a Lauta, por asumir con paciencia incalculable la tarea de discutir estas páginas las veces que hizo falta, porque de esas charlas surgieron las mejores ideas, por cocinar mientras escribo, por el amor. 
APOSTILLA $\quad \vdots \quad$ EN PRIMERA PERSONA 
Esta investigación iba a ser otra.

Durante el primer año de la beca doctoral que me otorgó el Consejo Nacional de Investigaciones Científicas y Tecnológicas me inscribí en el Doctorado en Historia de la Facultad de Humanidades y Ciencias de la Educación de la UNLP cuyo trayecto formativo es flexible y permite realizar seminarios en unidades académicas externas, en la medida en que estos se vinculen con el proyecto de investigación de las doctorandas y los doctorandos. En ese marco, cursé asignaturas correspondientes a la Maestría en Historia y Memoria de la FaHCE, al Doctorado en Ciencias Sociales de la Universidad de Buenos Aires (UBA) y al Doctorado en Artes de la FdA (UNLP), gracias a las cuales comencé a encontrar otros acercamientos posibles al objeto de mi investigación.

El plan de trabajo original estaba centrado en analizar las representaciones acerca de la cuestión Malvinas y el concepto de nación en la propuesta educativa oficial argentina. Pero a poco de andar surgieron interrogantes en torno a la relevancia de ese itinerario desde una perspectiva únicamente historiográfica. Se trataba de asuntos que acumulaban una gran cantidad de tratamientos en esa clave, lo que limitaba de algún modo el afán de realizar aportes. Sin embargo, tal presunción parecía debilitarse en el entrecruce del modo en que los mismos temas eran tratados específicamente en su faz estética.

En ese sentido, la indagación acerca de los materiales producidos por el Estado para enseñar parte de la historia nacional desde un enfoque atento a los posicionamientos historiográficos, sociológicos y políticos de sus contenidos pero ocupado del rol de la formalización en lo que atañe a su matriz compositiva se vislumbró como un camino más atrapante y versátil para realizar una contribución a esta área de conocimiento.

A partir de esas conjeturas, con el acompañamiento de mis directores y el aval de CONICET, a partir de 2017 decidí modificar el trayecto doctoral para profundizar una formación en las teorías del arte que me habilitara a indagar los aspectos formales y perceptuales de los materiales seleccionados como corpus de análisis en 
un proyecto de investigación que, a su vez, comenzó a tomar dimensiones más amplias de las que revestía en la instancia inicial.

El cambio de rumbo concedió los márgenes necesarios para conjugar el interés por tres planos que hasta ese momento se mostraban remotos en mi imaginario académico pero que convivían de hecho en el quehacer cotidiano: el arte, la política y las ciencias sociales.

Las explicaciones y las lecturas que pusieron a mi alcance quienes dictan los diferentes seminarios del Doctorado en Artes llegaron para ampliar y robustecer -o descartar en algunos casos - inquietudes previas, forjadas desde mi lugar de espectadora de las obras que luego se convirtieron en tejido medular del estudio. Y también vinieron a complementarse con aquellos textos y marcos conceptuales que ya habían dado forma a mi acercamiento al tema, desde una lente sociológica.

El abordaje del objeto fue nutriéndose, así, de los cruces, las mesas de diálogo y las producciones teóricas colectivas desarrolladas junto con los equipos de investigación Memoria y Violencia en el siglo XX y La historia reciente y los usos públicos del pasado, cuya sede fue el Instituto de Investigaciones en Humanidades y Ciencias Sociales (FaHCE-UNLP) y, en paralelo, de la participación en calidad de colaboradora en diferentes espacios de la Facultad de Artes, de la presentación de ponencias en jornadas vinculadas a las disciplinas artísticas, de la asistencia a conferencias organizadas por el instituto de Investigación en Producción y Enseñanza del Arte Argentino y Latinoamericano (IPEAL), y también de los debates en torno a estos asuntos realizados en ámbitos que tuve la suerte de frecuentar como integrante del comité editorial de una revista política y cultural, como docente, como graduada y como música.

Esta investigación iba a ser otra. Como bien saben quienes alguna vez se embarcaron en una tarea de plazo tan largo, la comparación entre el proyecto inicial y las conclusiones no suele resistir el archivo. Y esas deformaciones son bienvenidas en la medida en que reflejan la apertura a lo que Vigotsky llamaría zonas de desarrollo próximo, la distancia flexible entre lo que somos capaces de hacer en soledad y 
aquellos aprendizajes que se realizan en colaboración con otras y con otros originando, a su vez, nuevos grados de autonomía.

La intención de este racconto es, entonces, realizar una advertencia a las lectoras y a los lectores de los próximos apartados: la escritura final de la tesis que se presenta aquí se traza, antes que nada, como un intento de síntesis entre análisis formulados desde perspectivas epistemológicas disímiles y complejas que no siempre fueron zurcidas con precisión inmaculada. En más de un tramo la porosidad de esos bordes ha quedado al descubierto. Eso se debe, en buena medida, a la inclinación de la costurera por explorar un campo del saber en pleno movimiento a partir de operaciones interdisciplinarias que no desestimen las posibles fricciones. Pero también se guarda el anhelo de que allí, en esa ambigüedad, residan incógnitas que puedan convertirse en los primeros puntos de hilados propios y ajenos en adelante. 
"La patria es un dolor que aún no sabe su nombre.»

Leopoldo Marechal (1966) 
I NTRODUCCIÓ N 
Pensar la nación implica preguntarse por los límites geográficos, culturales, políticos y comerciales de una región imaginada. Requiere indagar en las disputas que ocasionó una nominación específica y en la delimitación de ciertos contornos que muchas veces guardan en su interior diferencias sustanciales en términos étnicos, religiosos y económicos. ¿Cuántas tramas se superponen dentro de los mismos bordes?

Para conocer una nación particular, sabemos, es necesario comprender las características de su política interna y su posición en el entramado regional e internacional; revisar los mapas, las proporciones, las ilusiones visuales, la hegemonía cultural de las potencias triunfantes y las trayectorias comunes de dependencia y de lucha por la autodefinición de los pueblos periféricos (Bohoslavsky, 2011; Oporto, 2011; Yepes, 2008).

El territorio ha sido, probablemente, el rasgo más cercano a la materialización de esta categoría intangible. En su exégesis moderna la nación se instituyó como una comunidad política limitada y soberana (Anderson,1993): el espacio. En ese sentido, la expansión de los organismos multilaterales, el auge de los sistemas mediáticos globales, las migraciones intercontinentales, el avance de los discursos posmodernos, por nombrar solo algunos rasgos del proceso de reestructuración capitalista que tiene cauce desde las últimas décadas del siglo XX, podrían haber bastado para firmar el acta de defunción del término y su vigor explicativo (Dupuy, 2005). Sin embargo, la nación logró sobrevivir a las mutaciones que erosionaron la estructura misma de los Estados liberales.

Entonces, pensar esta idea en la contemporaneidad nos mueve a dar un paso más. Nos insta a desentrañar la complejidad de los procesos de identificación, aquello que opera en planos no mensurables para hacer posible la convicción de que existe una unidad, el poder de la simbolización. Y si agudizamos el acercamiento para volverlo situado, debemos preguntarnos qué lugares han ocupado y ocupan la literatura, el teatro, la música, el diseño, la danza y las imágenes visuales y audiovisuales en el trazo de una filiación argentina y latinoamericana. Es decir, cómo ha operado el arte en la tarea de construir imaginarios sobre Argentina y sobre 
América Latina y, al mismo tiempo, cómo aquellas formas identitarias comunes dibujan derroteros posibles para las producciones artísticas del país y de la región.

Cobijado por la centralidad que adquieren esos intentos en tiempos de reconfiguración de los modelos políticos, económicos, culturales y artísticos en nuestro continente y en nuestro país, esta tesis tiene la modesta pretensión de ofrecer un acercamiento al modo en que el arte ha permitido simbolizar lo nacional en un caso específico: las propuestas audiovisuales y performáticas impulsadas por el Estado argentino en el marco del primer mandato de Cristina Fernández de Kirchner.

El escenario que comenzó a consolidarse con los gobiernos de Néstor Kirchner y de Cristina Fernández habilitó una reformulación en distintos planos de la construcción de sentidos en torno a la nación. Los nuevos lineamientos en lo que respecta a la política interna y externa expresados en la re estatización de YPF, la Asignación Universal por Hijo, el acercamiento a los organismos de Derechos Humanos, la Ley de Matrimonio Igualitario, la independencia del Fondo Monetario Internacional (FMI), el rechazo al Área de Libre Comercio de las Américas (ALCA), la creación de la Unión de Naciones Suramericanas (UNASUR) y de la Comunidad de Estados Latinoamericanos y Caribeños (CELAC), la reivindicación de la causa Malvinas, la alianza estratégica con líderes del continente y con potencias emergentes en fricción con los países centrales y la voluntad de enfrentar de manera mancomunada los obstáculos de la región -entre muchos otros-, implicaron nuevas definiciones acerca de lo nacional y de lo identitario.

A su vez, existen lazos dialécticos entre ese plano y determinados elementos del universo simbólico en los cuales es necesario detenerse para comprender de un modo más cabal los rasgos decisivos del modelo: tal como lo había hecho el movimiento peronista en su tiempo y, probablemente, gestionando esa herencia el kirchnerismo planteó una disputa en el ámbito de las imágenes visuales, sonoras y audiovisuales que funcionó como insumo y complemento de la puja económica. 
A partir de estas presunciones y en los intersticios de los estudios artísticos y sociológicos la investigación analiza cómo se desplegó la construcción simbólica de la nación en un conjunto de propuestas audiovisuales y performáticas desarrolladas en el marco del gobierno de Cristina Fernández de Kirchner, a instancias de los doscientos años de la Revolución de Mayo: ${ }^{1}$ la animación La asombrosa excursión de Zamba - dependiente del Ministerio de Educación de la República Argentina y emitida por el canal televisivo Pakapaka a partir de 2010-, los festejos del Bicentenario y las ficciones producidas por Canal Encuentro en torno a esa conmemoración: los largometrajes Belgrano, de Sebastián Pivotto (2010) y Revolución: el cruce de los Andes, de Leandro Ipiña (2011).

Para ello, en el capítulo uno se recuperan de manera sucinta los enfoques conceptuales que resultaron definitorios en el acercamiento al objeto de estudio y se explicita qué se entiende en esta tesis al hacer referencia a las categorías de nación, identidad, imagen, símbolo, metáfora, forma y desvío.

A continuación, el capítulo dos expone un análisis de la propuesta artística y cultural del kirchnerismo en un trazo más general y rastrea sus puntos de contacto con rasgos que en ese mismo ámbito revelaron los gobiernos peronistas. Se parte del supuesto de que este asunto involucra interrogantes acerca de la neutralidad de la forma y del grado de politicidad admisible para la experiencia estética y, en ese sentido, resulta convocante adentrarse en él desde una perspectiva que atienda a las teorías del arte contemporáneas y a su interés por examinar el vínculo entre arte y política, a instancias de la dupla estetización de la política/politización del arte (Acha, 1979; Benjamin, 1987; Clark, 2000; Rancière, 2005; Richard, 2007; Didi-Huberman, 2008).

En las secciones siguientes se propone un abordaje pormenorizado de cada una de las producciones seleccionadas. La serie de Pakapaka y los films de Canal

\footnotetext{
${ }^{1}$ Se entiende que los aniversarios patrios se constituyen como ocasiones favorables para que los gobiernos impulsen propuestas conmemorativas dirigidas a disputar y a actualizar las representaciones sobre la identidad nacional (Cattaruzza, 2007; Bisso y Kahan, 2014; Amorebieta y Vera, 2019).
} 
Encuentro fueron desarrollados bajo la tutela del Ministerio de Educación y emitidos por dos canales educativos y públicos de la Argentina. Por su parte, la organización de los festejos de la efeméride patria estuvo a cargo de la Unidad Ejecutora Bicentenario de la Revolución de Mayo 1810-2010 conformada, en buena medida, por miembros del poder ejecutivo. En este sentido, los capítulos tres, cuatro y cinco abordan estos dispositivos como medios de aproximación a las representaciones en torno a la nación legitimadas y promovidas oficialmente por el gobierno en el Estado. A su vez, se considera que existen singularidades en cada uno de los materiales elegidos que permiten rastrear aspectos relevantes para conocer el modo en que se formalizó esa idea en el período referido.

El festejo bicentenario es analizado en su carácter de obra, por el modo en que su intervención en el espacio público transformó a la ciudad en escenario y a los transeúntes en espectadores. El capítulo indaga especialmente en las características de algunos de los eventos más destacados dentro de la semana de celebración -a saber: los conciertos de homenaje a distintos géneros musicales en la 9 de julio, el videomapping sobre la historia de la nación argentina y el Desfile del Bicentenario montado por el grupo Fuerza Bruta-, para reconocer en ellos el despliegue de imágenes identitarias.

En cuanto a los antecedentes, cabe decir que el estudio de este acontecimiento ha ofrecido un cuerpo muy vasto de trabajos orientados a revisar asuntos diversos: el carácter fundacional de los actos conmemorativos en lo que respecta a la constitución de identidades políticas, los contrastes con la celebración del centenario, el papel de distintos actores en la transmisión de una historia oficial, los usos políticos del pasado en el presente, los puntos de contacto con los festejos bicentenarios en otros países latinoamericanos, las representaciones que circularon allí en torno a la idea de revolución, el lugar de los pueblos originarios en el festejo, las tensiones entre pueblo y Estado en la configuración de subjetividades colectivas, el espacio público como terreno de disputa, entre otros (Giarraca, 2011; Sotelo, 2011; González, 2015; Stortini, 2015; Suriano, 2015; Molinaro, 2013; Perochena, 2018; Amorebieta y Vera, 2019). 
Aquí nos valemos de la existencia de esos abordajes para permitirnos anclar nuestra aproximación específicamente en la propuesta artística desplegada en los cuatro días que duró la fiesta y en sus estrategias para simbolizar una idea de nación latinoamericana. A su vez, rastreamos la construcción formal de la Semana del Bicentenario desde una perspectiva que, sin rehusar obstinadamente de la identificación de influencias foráneas, permanece atenta a aquellos rasgos que dejan vislumbrar un modo regional de producción del arte.

En el cuarto capítulo, la animación La asombrosa excursión de Zamba es observada como una importante punta de lanza en lo que concerniente a la contienda simbólica librada por el kirchnerismo, a raíz de la creación, por parte del Ministerio de Educación de la Nación en el año 2010, del primer canal educativo destinado a un público infantil. El programa surgió a instancias de la celebración bicentenaria con el objetivo de transmitir una mirada acerca del tema mediante una ficción dirigida, centralmente, a los niños. Desde su momento germinal fue pensado como un producto para el consumo masivo, permeado por los códigos televisivos y digitales y orientado a un público concreto. Por otra parte, la serie propuso una intromisión directa en un terreno que había sido siempre patrimonio de las instituciones educativas. Zamba no se acerca de un modo neutral al pasado y, por esto mismo, invita a cuestionar algunas explicaciones, abre caminos alternativos para pensar la historia, visibiliza memorias y construye significantes a partir de determinadas decisiones formales.

La decisión de asumir ese desafío le ha valido al material un lugar en el centro de los cuestionamientos mediáticos y, a su vez, en las indagaciones de buena cantidad de trabajos académicos. Existen escritos que abordan la serie para rastrear allí las características de su revisión historiográfica, la memoria histórica legitimada en su discurso narrativo o el posicionamiento oficial respecto de determinado acontecimiento a partir del análisis de un episodio particular (Gullino, 2013; Murolo, 2013; Castro \& Pardo, 2015; Gastaldi, 2015; Tobeña, 2015; Fernández Presa, 2017). Otros trabajos la asumen como un insumo para reflexionar sobre asuntos más generales como el proceso de democratización de la comunicación audiovisual, las 
tensiones entre Estado y mercado en la factura de la propuesta, las transformaciones contemporáneas de la comunicación, los procedimientos paródicos en las estrategias educativas, la producción de sentidos en torno a la niñez, el lugar de las tecnologías en tanto dispositivos sociales y la animación como recurso pedagógico, entre otros asuntos (Martínez Alonso, 2012; Bernardo, 2015; Crivelli, 2015; Linare \& Cuesta, 2015; Andrade, Carnevale y Massone, 2016; Castrillón, 2017; Castro, 2018).

Sin desatender la lectura compleja de las investigaciones mencionadas, nos detenemos especialmente en una particularidad clave del material estudiado: la de haber propuesto una aproximación compleja en los planos del tiempo, el espacio y la forma. El protagonista es un niño formoseño de ocho años que vive en el presente y que en cada episodio realiza un viaje temporal para presenciar diferentes momentos de la historia y establecer diálogos con personajes del pasado. Pero, a la vez, Zamba es un dibujo animado y el San Martín, la Juana Azurduy, el Sarmiento o el Galtieri que interactúan con él no son representaciones del mundo natural sino productos artísticos que se materializan a partir de decisiones formales (tamaño, color, escala, encuadre, musicalización). El énfasis está puesto, entonces, en el análisis de los aspectos que definen la formalización del material: su imagen visual, su imagen sonora y los vínculos entre esas esferas.

Por último, en lo que respecta al corpus que rodea a Canal Encuentro como objeto de estudio existen investigaciones que abordan problemas específicos, por ejemplo, el relato de la historia reciente propuesto en sus documentales (Durán, Litvinoff, Roldán, Tomassoni, s/f), las apropiaciones pedagógicas de estos materiales en las escuelas (Abramowski \& Igarzabal, 2011; Buletti, 2017), las narrativas de la ciencia en la televisión digital (López, 2011), los elementos identitarios en el diseño de la marca del canal (Fernández, 2014; Salem, 2012), las características de un programa en particular dentro de la propuesta integral (Trotta \& Santucci, 2010; Cinícola, 2014) o el proceso de surgimiento y de armado institucional de la señal, su devenir y sus propósitos (Smerling, 2015; Corte, 2016;).

Nos hemos servido de esos escritos con el objetivo de comprender de manera más compleja el contexto de producción de dos largometrajes cuya factura respondió 
a la iniciativa de ofrecer un relato sobre la guerra de independencia y la fundación de la República y en torno a los cuales los análisis académicos pormenorizados representan una porción aún bastante acotada. Belgrano y Revolución: el cruce de los Andes son estudiadas en el capítulo cinco considerando especialmente sus operaciones retóricas y la tensión entre ambigüedad y realismo dentro de sus recursos narrativos.

La indagación fue construida a partir del visionado de los materiales seleccionados - tanto en el caso de la tira animada como en lo que respecta a los largometrajes de Canal Encuentro- y del registro audiovisual de los Festejos del Bicentenario, todos ellos disponibles en plataformas virtuales de acceso público. A su vez, se recurrió a fuentes secundarias indirectas para poner en diálogo conclusiones parciales del estudio con análisis previos en torno a los mismos objetos. La confección de esta muestra no persiguió fines de generalización sino de profundidad analítica. ${ }^{2}$

En la aproximación a todos los materiales, se identificaron los contenidos históricos, políticos y culturales abordados para luego analizar las elecciones compositivas desplegadas en su poetización. El rastreo del desarrollo simbólico y de las imágenes creadas a partir de esas formalizaciones fue realizado desde el marco

\footnotetext{
2 Para su abordaje se plantearon los siguientes objetivos específicos: A) Reconstruir los distintos contextos de producción de cada una de las propuestas que forman parte de la muestra. B) Identificar la selección temática y la construcción argumental en los episodios que componen la serie infantil, en la propuesta artística de los festejos bicentenarios y en las ficciones de Canal Encuentro. C) Analizar en cada caso las elecciones compositivas desplegadas para formalizar contenidos históricos, políticos y culturales y generar imágenes a partir de ellos. D) Reponer las operaciones metafóricas presentes en los materiales elegidos en torno a las dimensiones que permiten volver aprehensible el concepto de nación. E) Trazar vínculos entre los materiales a partir de las consideraciones parciales referidas a sus operaciones metafóricas y a sus desarrollos formales. F) Caracterizar la elaboración simbólica de la idea de nación en las propuestas impulsadas por el Estado argentino durante el período referido.
} 
ofrecido por los pares de opuestos literalidad-ambigüedad, figuración-abstracción, cercanía-distanciamiento y realidad-ficción, siempre en el eje circundado por las elecciones artísticas.

A su vez, se confrontaron casos específicos de operaciones metafóricas en torno a ideas como patria, territorio, soberanía, identidad nacional, héroes, pueblo, memoria, historia, olvido, cultura, etcétera, formuladas en las producciones elegidas. Estos conceptos fueron entendidos como dimensiones que permitieron volver aprehensible el carácter polisémico de la idea de nación y con respecto a ellos se tornaron especialmente significativos los énfasis, las omisiones y las combinaciones disímiles.

El trabajo se llevó a cabo desde una perspectiva de análisis interpretativa que intentó sortear la clásica oposición forma/contenido, como puntualizaremos en el próximo capítulo al definir nuestros marcos conceptuales. Se entiende que la configuración de ciertos imaginarios en el sentido más amplio del término y el modo en que estos son plasmados en cualquier soporte no trazan planos indiferentes; no existen por un lado los «contenidos sociales» - la soberanía, la guerra, la Dictadura, la escuela, la revolución - y por otro los abordajes neutros - los énfasis, los silencios, las caracterizaciones, los títulos, etcétera-. La forma, de este modo, deja de ser el reverso del sentido o su envoltorio neutral para convertirse en un aspecto decisivo de la totalidad.

Desde ese enfoque, se considera que el cruce entre la sociología, la historia y el arte aquí propuesto ofrece un modesto aporte al corpus de estudios que toman como objeto el tratamiento de lo nacional en las propuestas producidas por el Estado argentino, a partir de un análisis detenido especialmente en la formalización de los materiales seleccionados, en vínculo con sus pretensiones de masividad. 
C A P ÍT ULO $1 \quad 1 \quad \vdots$ LOS MARGOS 
"Se hace difícil, por no decir prácticamente imposible, contar la historia desde una no-identidad, desde ninguna parte, lo que no implica que este sea el reino de la subjetividad. Puede ser, sí, el reino de las identidades puestas en función política. Los que creen escribir desde ninguna parte, desde una supuesta neutralidad, terminan convirtiendo a la historia, a la memoria, en otra forma de simulacro.»

Adolfo Colombres ([1987] 2007)

En un escrito publicado en el primer número de la revista Octante de la Facultad de Artes, Mariel Ciafardo (2016) refiere al modo en que la colonización conceptual presente en ciertas metodologías de análisis impide reconocer el derecho a la contemporaneidad de las artes visuales de nuestro continente. La autora advierte:

Un cambio radical de la actitud teórica frente al arte - al nuestropermitiría formular algunas preguntas impostergables. Por ejemplo: ¿Existe un arte visual contemporáneo latinoamericano? ¿Es posible visualizar en las obras contemporáneas latinoamericanas rasgos formales (en sentido amplio: composición, paleta, materiales, ritmos, etcétera) cuyo origen se remonte a las producciones de la América profunda?, ¿̇o, por el contrario, es más evidente la influencia del arte de vanguardia europeo? ¿El problema es el de las formas de las obras o se trata de un conflicto de orden teórico? ¿Cómo irrumpen - si es que lo hacen - las formas del pasado, más allá (y pese a) las formas preestablecidas por la Europa moderna? ¿A qué se debe esa imposibilidad de ver, esa negación de la mirada? (pp. 24 y 25 ).

Análisis similares podrían echar luz sobre la encrucijada en la que se encuentran los enfoques que intentan ceñir otras prácticas artísticas nacidas y criadas en Latinoamérica a los márgenes clasificatorios impuestos por los centros mundiales del arte y que, en ese afán, restringen su abordaje. Hablamos de canciones, poemas, escenografías, diseños, coreografías, instalaciones, guiones teatrales, fotografías, películas y series de televisión que presentan formalizaciones no del todo ajustables a los parámetros de estandarización europeos o norteamericanos y cuya interpretación requiere un abandono de la racionalidad colonial que muchas veces circunscribe nuestras exploraciones.

Esas formas impermeables al uso de categorías analíticas importadas incitan a consumar nuevas praxis investigativas y pedagógicas suscriptas al paradigma de 
aquello que Boaventura de Sousa Santos (1995) llamó epistemología del sur«aprender que existe el Sur, aprender a ir hacia el Sur, aprender desde el Sur y con el Sur»- y que podría enhebrarse en una urdimbre de pensamiento latinoamericano en la cual Simón Rodríguez, el maestro de Bolívar, dio los primeros embates con su «inventamos o erramos», allí por el tiempo de los primeros bocetos de patria grande (Wainsztok \& otros, 2013).

Este capítulo recupera el marco teórico del que nos hemos valido para llevar a cabo la investigación. Muchas de las definiciones incluidas aquí fueron formuladas por autores extranjeros, en latitudes distantes y en tiempos lejanos al nuestro. No obstante, la compilación de esos enunciados se realiza en la tesis acompañada del esmero por dilucidar, uno a uno, los elementos que colaboran con nuestro enfoque específico, situado y siempre atento a efectuar esfuerzos teóricos que sean capaces de nutrirse también de líneas de pensamiento nacionales y regionales, ponderando a todas ellas bajo el mismo efecto de contemporaneidad y con igual valor explicativo.

\section{De qué hablamos cuando hablamos de}

\section{nación}

La preeminencia de la nación como categoría identitaria, capaz de aglutinar en su interior el enlace a una comunidad política y el reconocimiento de un conjunto de símbolos y sentidos en torno a ella, ha sido reafirmada a pesar de las discusiones en torno a su vigencia en tiempos de vínculos globalizados y fronteras difusas. La nación persiste como marco interpretativo ineludible al momento de pensar la vida de los sujetos en sociedad (Dupuy, 2005; Campi, 2006; Grimson, 2007; Loza, 2012). ${ }^{3}$

\footnotetext{
${ }^{3}$ En una entrevista realizada por Nadia Hakim Fernández (2014) a Alejandro Grimson, frente a la pregunta por la pérdida de poder del Estado Nación como categoría explicativa el antropólogo contestó: «El declive no puede afirmarse teleológicamente como algo necesario o inevitable. Manuel Castells estuvo visitando nuestro instituto dos veces. La primera de ellas hace tres años y yo le pregunté por qué pronosticaba en La era de la información el debilitamiento inexorable del Estado Nación, y él me dijo dos cosas. Primero, que lo único que puede pronosticar la sociología es el pasado, y, lo segundo, es que él planteó eso porque no se imaginó que podía ocurrir lo que está ocurriendo en
} 
Esa confirmación reflota, indefectiblemente, la pregunta por la posibilidad de delinear una exploración teórica acerca de este concepto inenarrable y el interés por su relación con otras nociones que, a primera vista, aparecen adheridas a aquél de un modo gravitante. Reparemos, por ejemplo, en lo que ocurre con las categorías de patria, pueblo y Estado.

Un apunte perdido en un antiguo cuaderno de historia social reza: «La patria es el sentimiento de pertenencia a un territorio ordenado como nación, la cual en su organización política se presenta como Estado y cuyo sujeto soberano es el pueblo». Al buscar en el diccionario de la Real Academia Española la palabra patria encontramos que esta es descrita como la «tierra natal o adoptiva ordenada como nación, a la que se siente ligado el ser humano por vínculos jurídicos, históricos y afectivos» (Real Academia Española, 2020), ${ }^{4}$ mientras que la nación es el «conjunto de los habitantes de un país regido por el mismo Gobierno» (Real Academia Española, 2020) ${ }^{5}$ descripción que, en una lectura apresurada, podría valer también para la idea de pueblo. El Estado, por su parte, es catalogado como una «forma de organización política, dotada de poder soberano e independiente, que integra la población de un territorio» (Real Academia Española, 2020)..$^{6}$ El pantano se vislumbra profundo.

La definición unívoca de categorías tan vastas como las mencionadas entraña una tarea espinosa cuya resolución se nos plantea a modo de incógnita: ¿̇es viable cristalizar una máxima sobre estos términos sin reconocer los debates teóricos y políticos referidos a sus fronteras como parte constitutiva de esas acepciones anheladas?, ¿ cómo comprender de manera compleja su significado sin adentrarse en la variación de los sentidos que les han sido adjudicados en distintos períodos a lo

América Latina. Yo agregaría que hay más nacionalismo en Estados Unidos que hace diez años, en Rusia el nacionalismo es muy fuerte, como en China. ¿Que no hay nacionalismo en Japón, en Alemania o en Inglaterra? ¿De qué mundo hablamos cuando decimos que está debilitado el nacionalismo?» (p.267)

${ }^{4}$ Real Academia Española (2020). Patria. Recuperado de https://dle.rae.es/patria

${ }^{5}$ Real Academia Española (2020). Nación. Recuperado de https://dle.rae.es/naci\%C3\%B3n

${ }^{6}$ Real Academia Española (2020). Estado. Recuperado de https://dle.rae.es/estado 
largo de la historia e, incluso, en las disputas que suscitó su evocación en cada tiempo particular?

Al respecto resulta sugerente el análisis que propone Mario Oporto (2011) al cotejar el modo en que la historiografía ha construido la idea de nación en nuestro país:

En general, las corrientes historiográficas en la Argentina se clasifican de manera amplia: la de los liberales, la de los revisionistas, la de los marxistas. Podríamos agregar también a los historiadores formados en ciencias sociales. Todos ellos, al abordar la Historia, parten de una definición de Nación y, en segundo lugar, de una toma de posición sobre cuándo comenzó la Nación. ${ }^{7}$ Hay quienes sostienen que la Nación comenzó antes de la llegada de los españoles. Otros dicen que la Nación es hispana, y que por lo tanto nació con la llegada de los españoles pero no en América, sino en España, y que ahí hay que buscar las raíces nacionales. Y no faltan aquellos que identifican Nación con la Independencia y por lo tanto la sitúan en 1810 o en 1816; si es que no afirman -otros más- que la Nación nace como estado nacional burgués a fines del siglo XIX. Y cabe resaltar que, de cada idea de nación surge un concepto diferente de unidad (pp. 22-23).

Para comprender el funcionamiento de este constructo, entonces, es imperioso remitir a su carácter cultural irresuelto y considerar al conflicto como un elemento constitutivo de su devenir.

Veámoslo desde un enfoque más distante y extendido temporalmente. En su rastreo de las constancias y modificaciones del término nación en la historia conceptual, Alessandro Campi (2006) analiza cómo en sus orígenes, durante la Antigüedad, la nacionalidad era asociada a cuestiones míticas, religiosas, de parentesco y a la delimitación étnica de distintas poblaciones, y cómo los componentes territoriales y culturales fueron importantes también durante la Edad Media, cuando comenzaron a delinearse conformaciones más reducidas - ciudades o pequeñas provincias-, al tiempo que surgían lazos de pertenencia comunitaria entre poblaciones distantes a partir del comercio, la religión, la lengua y el arte.

La modernidad, según el politólogo italiano, dio paso al protagonismo de tres modelos de pensamiento en torno al concepto. La perspectiva estatal, centrada en la

\footnotetext{
${ }^{7}$ Las mayúsculas son del autor.
} 
relación entre el crecimiento del poder del Estado, con su maquinaria administrativa de lo público, y la creación de valores de pertenencia nacional como garantía de la cohesión interna; la visión cultural, atenta al reconocimiento de una comunidad popular - previa y diferenciada con respecto al Estado- basada en la lengua, el territorio y las tradiciones; y la alternativa política soberana que reconoció a la voluntad ciudadana como el fundamento central del de la nación, con su caso paradigmático en Francia. Este fue el gesto predominante en el siglo XIX, cuando como correlato de la Revolución y de la caída del absolutismo la idea de nación comenzó a acercarse cada vez más a las de patria y pueblo, con la institución de nuevas identidades colectivas.

Ya en el transcurso del siglo XX adquirieron preponderancia las controversias alrededor del contorno ficcional de la nación, con el nacionalismo como componente medular de los análisis y el foco puesto en los procesos de identificación, recepción, exclusión, negociación y exterminio subyacentes a esas filiaciones, de modo alternativo según el territorio específico (Anderson, 1993; Rosaldo, 1992; Elías, 1997).

¿Qué actores participan en la construcción de esa categoría tan inefable como perenne?, ¿cuántos exterminios se legitimaron en su nombre y cuántos grados de libertad fueron conquistados bajo el manto de esa unidad heterogénea?, ¿cómo se configuran la memoria y el olvido al interior de estas construcciones móviles?, ¿cuáles son los relatos que disponen un entendimiento acerca de sus márgenes y de sus propiedades en cada caso?

Esos interrogantes se prolongan a nuestros días y se aprecian cardinales en momentos que esbozan los itinerarios potenciales para nuestros territorios. Pensar los conceptos políticos por fuera de su temporalidad y de su espacialidad puede convertirse en una misión tan caprichosa como estéril. Lo que intentamos aquí es rodear estas ideas en un gesto que no pretende ceñir su significación sino, por el contrario, aceptar su polisemia y, en última instancia, estudiar el modo en que otras y otros resolvieron su abordaje desde el punto de vista estético. 


\section{imagen, símbolo, metáfora, forma, desvío}

Si una estudiante de primer año de cualquier carrera de la Facultad de Artes busca la palabra imagen en el google uno de los primeros resultados arroja la siguiente definición:

La imagen (del latin imago) es una representación visual que manifiesta la apariencia visual de un objeto real o imaginario. Aunque el término suele entenderse como sinónimo de representación visual, también se aplica como extensión para otros tipos de percepción, como imágenes auditivas, olfativas, táctiles, sinestésicas, etcétera (Wikipedia, 2018). ${ }^{8}$

Esta síntesis agrupa sin solución de continuidad —como ocurre muchas veces con las fuentes en el ciberespacio- dos perspectivas acerca del concepto. De un lado, la tradicional noción de imagen como copia, como retrato, como imitación visual de la apariencia de un objeto. Del otro, una descripción más amplia del término, dentro de la cual logran colarse aquellas dimensiones que carecen de corporeidad tangible, por ejemplo, las palabras, los aromas y la música.

Para Jean Paul Sartre, la imagen es conciencia imaginada, una relación recíproca de la conciencia con el objeto: «una manera determinada que tiene el objeto de aparecer a la conciencia, o, si se prefiere, una determinada manera que tiene la conciencia de darse un objeto» $(1976$, p.2). Desde esta mirada, el concepto se aleja de la clásica asociación imitativa. Podemos imaginar aquello que no existe: el aspecto del personaje central de un relato que escuchamos atentos, el perfume de una flor que no conocemos, la cabellera larga de la doncella en la torre de un reino muy lejano, una melodía que aún no ha sido escrita por nadie.

Por su parte, Jean Chateau analiza cómo, mientras que el animal «permanece adherido a la realidad» (1976, p. 186), los sujetos somos capaces de representar, de realizar sobre esa misma realidad una operación de añadidura a partir de la experiencia, de la cultura, del cuerpo, del deseo. La subjetividad interviene en

\footnotetext{
${ }^{8}$ Wikipedia. (2018). Imagen [Entrada de página]. Recuperado de https://es.wikipedia.org/wiki/Imagen
} 
nuestra construcción de imágenes y la atribución de cualidades que hacemos en esa composición se separa de la mera representación neutral.

A la extensa caracterización de las imágenes visuales realizada por Jacques Aumont (1992) en un libro ya clásico que casi agotó el tema con un desarrollo que agrupa desde cuestiones funcionales ópticas, químicas y nerviosas hasta las diferentes concepciones que incluyen la temporalidad, la espacialidad, la percepción del movimiento y las complejas relaciones de la imagen con lo real, y al no menos conocido acercamiento a una definición del arte de José Jiménez (1986), donde define a este concepto como una producción de imágenes ficcionales, puede añadirse una vasta producción teórica gestada en las últimas décadas que permite teorizar este concepto a partir de una fisura producida por el debate de las Ciencias Sociales con relación a la asimetría entre palabra y mundo real o, si se prefiere, entre razón y percepción (Casullo, Forster \& Kaufman, 2009). Desde esa lógica, la imagen no funciona como una construcción racional guiada por el pensamiento moderno sino como lo imaginado. Esto abre senderos complejos: puede existir una imagen estética - visual pero también sonora, corporal, literaria, conceptual, etcétera- de algo que todavía no ha nacido.

Entonces, las imágenes son algo más que copias fieles y objetivas del mundo sensible que nos rodea. Incluso, según la interpretación de Georges Didi Huberman (2006) que, a su vez, retoma a Aby Warburg, la imagen puede ser pensada como un síntoma -en el sentido crítico y no clínico del término-, como un malestar en la representación, porque indica un futuro que aún no sabemos leer, ni, incluso, describir. El planteo de recuperar la mirada histórica desde la imagen -en este caso la escogida para el tratamiento de lo nacional en las distintas propuestas seleccionadas - intenta rescatar esta noción como aquella que tiene la capacidad de acuñar las contradicciones profundas, los secretos más íntimos que operan en regiones encriptadas sin resolverlas y dan lugar, así, a posibles reescrituras.

En sintonía con esta idea podemos pensar la noción de símbolo. Según Ernst Cassirer (2007), la capacidad de simbolizar es la más específica de las cualidades humanas. Somos animales simbólicos. El símbolo porta un sentido, un contenido que 
no está presente y que requiere una comprensión. Cuando ese sentido es descubierto por el sujeto y es encarnado por él, se personaliza y se transforma en significación.

La tradición comunicacional, fundamentalmente en el campo del diseño, ha estado determinada casi de manera excluyente por una asimilación de los conceptos de signo y símbolo en la que el segundo se subsume en el primero. Hablamos de la influencia de las categorías lingüísticas - trasladadas en muchos casos de manera mecánica y acrítica- en el campo de la estética. ${ }^{9}$ Esta corriente, fundada también en los estudios postestructuralistas y hermenéuticos, ha tenido gran impacto en las décadas del ochenta y del noventa pero fue, en cierto modo, relativizada por investigaciones que en algunos círculos se rotularon como «el retorno de la metáfora». En esa línea, Adolfo Colombres (2005) distingue símbolo y signo justamente en un rasgo que acerca su operatoria a lo metafórico. Dice el autor:

Hay quien considera al símbolo un tipo especial de signo, pero acaso resulte más apropiado y conducente tomarlo como elemento de distinto orden. En efecto, en el signo la conexión que se establece entre el significado y su forma es arbitraria pero unívoca. Por ejemplo, la luz roja como señal de tránsito indica que es preciso detenerse y cualquier duda o error de interpretación sobre esto sería fatal. Se podría haber estipulado que cumpliera ese mismo objetivo una luz azul, pues entre el color y el hecho de detenerse no existe un nexo necesario. Igualmente arbitrarios son los signos lingüísticos que expresan los sonidos de una lengua. En el símbolo, por lo contrario, la relación entre la forma y el significado tiene, sí, algo de necesaria. Si se dibuja un círculo para aludir a la eternidad no se trata de una pura convención, puesto que el círculo, al no tener principio ni fin, se parece a la eternidad, que tampoco los tiene. Pero el círculo posee también otros significados, así como el concepto de eternidad contiene otros conceptos semánticos no alcanzados por la idea de círculo. $Y$ esto ha de ser así porque si el símbolo se tornara unívoco se convertiría de hecho en un signo, ya que lo que caracteriza en definitiva a aquél es su ambigüedad, el juego de la polisemia (p.17).

En suma, según Colombres, mientras el signo es arbitrario y unívoco, el símbolo es semejante y polisémico. Se trata de la unión de dos imágenes que comparten cualidades imitativas y descartan sus diferencias.

\footnotetext{
${ }^{9}$ Ver: Biord Castillo, P.R. (1996). Del signo al símbolo. Anthropos, (32-33), 21-44.
} 
Para Tzvetan Todorov (1991) el proceso de simbolizar implica reconsiderar una realidad fáctica y sustituirla por otra que la sintetice, a partir de contornos identificatorios y selectivos. Allí intervienen aspectos culturales, emocionales y cognitivos para construir una representación a partir de rasgos que se vinculan por una convención aceptada socialmente. Los símbolos son formas del pensamiento colectivo que no se limitan a reflejar al mundo sino que lo recrean. En esa línea, HansGeorg Gadamer (1996) advierte que mientras el signo remite a una señal fundada de manera arbitraria, el símbolo supone un nexo metafísico entre lo visible y lo invisible.

En ese sentido, el símbolo funciona de manera similar a la metáfora. La operación metafórica permite aceptar una cosa por otra o incluso una cosa en otra. Pero la metáfora es solo una de las posibles transformaciones simbólicas. En ella hay una conciencia clara de no identidad que da cauce a un ente inédito. Capta un parecido entre dos cosas - por ejemplo labios y rubíes, ojos y estrellas - y los significados de alguna de ellas se adormecen. Pero cuando una metáfora adquiere categoría de símbolo es porque se ha extendido a lo largo del tiempo, se ha repetido hasta transformarse en una convención, como en el caso de la cruz cristiana, la bandera argentina, etcétera (Belinche, 2017).

Resta añadir a estas dilucidaciones sobre imagen, símbolo y metáfora alguna acotación acerca de la forma. En este escrito no usaremos la noción de forma como sinónimo de la idea de estructura. Si optamos por simplificar podemos decir que la estructura es a priori y la forma es en acto y que esta última deviene en distintas variables posibles de la estructura. Algunos ejemplos: el acorde de Do mayor propone una estructura fija que dispone por lo menos tres alturas de manera simultánea, pero los modos en que ese acorde se puede ejecutar e intervenir en una obra son múltiples. La Sonata establece un esquema fijo y una estructura que dispone un primer tema, un segundo tema, etcétera. Pero no hay una Sonata igual a otra. Por lo tanto, cuando hablemos de forma - término fácil de utilizar y difícil de explicarharemos alusión al conjunto de relaciones que se producen en una unidad donde los materiales se organizan temporal y espacialmente generando la ilusión de un adentro y un afuera (Ligeti, 1987). 
Otra característica de la forma, desde una perspectiva dinámica y contemporánea, es que cualquier cambio en la disposición o en la intervención de los materiales altera el resultado. Un círculo rojo sobre un fondo blanco idéntico a otro círculo gris sobre un fondo blanco no difiere en sus contornos ni en su proporción pero sí en su nivel de contraste. Por consiguiente, las nociones de figura y fondo y la pregnancia de uno y de otro producen un cambio formal. Desde esta mirada, la forma no es contorno, continente, organización, es contenido de la experiencia.

En la constitución interna de este concepto, así entendido, subyace un comportamiento móvil que puede asumir el vocabulario proveniente de la literatura y de categorías trabajadas por el formalismo ruso. En su escrito «El arte como artificio», Víktor Shklovski ${ }^{10}$ introduce la noción de desvío o extrañamiento como ruptura con el medio automático en el que se refugian nuestras acciones al repetirse y transformarse en hábitos. La automatización devora la vida, dice Shklovski, y la finalidad del arte consiste, justamente, en oscurecer la forma aumentando el tiempo que conlleva la percepción para liberar a los objetos y a los actos y así lograr volver a verlos por primera vez.

Tal posibilidad de desautomatización alude al modo en que se organizan los materiales en el interior de una obra ficcional y no al tema al que refieren. Los pares forma/contenido y tema/trama sin duda ajustan cuentas en cada uno de los inconclusos pero incesantes intentos por definir qué es el arte. Sin aventurarnos en esa tarea espinosa diremos que la formalización, además de organizar poéticamente los elementos, cumple el rol de desnaturalizar la percepción y esto incluye la percepción de la historia y del presente. Por lo tanto, la forma no es neutral y la pregunta en el arte no puede resumirse solo a "qué dice esto» o a "qué muestra esto» sino que debería incluir el interrogante acerca de "cómo está hecho esto» o «cómo es esto».

Un comentario final: las definiciones ontológicas, epistemológicas y conceptuales de las categorías de símbolo, signo, metáfora y forma siempre resultan

10 Se trata de un artículo escrito por Shklovski en 1916 al que hemos accedido a partir de la compilación de Tzvetan Todorov (1970) en su libro Teoría de la literatura de los formalistas rusos. 
riesgosas. En primer lugar porque han mutado a lo largo de la historia y en segundo lugar porque los horizontes entre esas nociones son tan difusos que derivan, en ocasiones, en equívocos, dado que en todos los casos presuponen conceptos operatorios que abarcan en su interior otros conceptos más tangibles. A pesar de esto y con el propósito de fijar al menos un punto de partida que permita alumbrar de qué hablamos cuando hablamos de, podemos asumir algunas conjeturas. La primera es que se trata de nociones muy cercanas entre sí y que difieren más en matices que en sustancia: la forma es capaz de enlentecer la percepción a partir de operaciones metafóricas, la metáfora es un símbolo no convenido socialmente, el símbolo es un tipo singular de unión entre imágenes y la imagen puede ser metafórica, formal y simbólica lo que, por lo tanto, admite un empleo versátil de estos términos. La segunda es que en todos los casos late una lejanía, una distancia con el objeto representado o concebido, un modo de mostrar y de ocultar al mismo tiempo. Y es esa distancia, esa especie de mirada estrábica, distorsiva respecto de lo dicho o lo mostrado, lo que les otorga su carnadura.

Por lo tanto, en el análisis de los casos seleccionados intentamos ahondar en las estrategias empleadas tanto para generar la presencia del concepto de nación como para eludirlo. Entendemos que el arte trabaja y se nutre de la tensión alimentada por esa ambigüedad, supone una conducta de rodeo del objeto y no su completa posesión. 
CAPÍTULO $2 \quad \vdots$ EL ACGESO A LA FORMA 
«Gracias, muchísimas gracias. Muchísimas gracias a todos. Me alegro mucho de que estén acá - dice Piglia ante el aplauso sostenido del público entusiasta y heterogéneo que colma el estudio-. Me alegro mucho también de que podamos encontrarnos para hablar sobre Borges. Para hablar sobre Borges en la Televisión Pública, donde lo lógico sería hablar de Jauretche en un principio, ¿no? Pero nosotros vamos a hablar de Borges» (Televisión Pública, 2013, 00:26:00).

Así comenzó la primera entrega de una producción realizada en 2013 por la Televisión Pública Argentina y la Biblioteca Nacional en el marco de la cual el escritor Ricardo Piglia ofreció cuatro clases abiertas sobre la obra de Jorge Luis Borges. Esos programas especiales recuperaron un formato testeado un año atrás con Escenas de la novela argentina, un ciclo en el que Piglia presentaba a los principales novelistas nacionales para abordar distintos aspectos de ese género ante un público conformado por docentes y estudiantes universitarios. En Borges por Piglia la propuesta consistió en formular para cada emisión distintas puertas de entrada a la obra de uno de los autores más relevantes de la cultura argentina, a partir de una serie de preguntas inquietantes: por qué Borges es un buen escritor, qué lo convierte en un autor nacional, cuál fue su linaje, cómo leía, por qué resulta contemporáneo, cómo ingresaba la política en su literatura, entre otras.

La apuesta a estas clases públicas se revela osada no solo por haber implicado en su factura la asociación compleja entre dos instituciones tan distintas como una biblioteca y un canal de televisión -aspecto que, según sostuvo el por entonces director de la Biblioteca Nacional, Horacio González, implicó desentrañar «lo que tiene de biblioteca un organismo como la tele y lo que tiene de aspecto visual el mundo de los libros» (Télam, 2013) - ${ }^{11}$ sino fundamentalmente por algo que Piglia se encargó de explicitar en el último episodio del ciclo: «Borges era un hombre de derecha y lo decía».

\footnotetext{
${ }^{11}$ Télam (2 de septiembre de 2013). Piglia dictará una serie de clases sobre Borges en la TV Pública. Disponible en https://www.telam.com.ar/notas/201309/31046-piglia-dictara-una-serie-de-clasessobre-borges-en-la-tv-publica.php
} 
Uno de los temas clásicos del debate estético ha sido el del lazo entre la producción artística, su circulación y su recepción. Se trata de un asunto escabroso, fundamentalmente si consideramos que el arte occidental estuvo circunscripto durante largo tiempo al consumo de un sector muy específico de la sociedad cuyo desplazamiento más significativo se dio de la aristocracia a la burguesía y que, recién en el siglo XX, la aparición de las masas y los planteos teóricos de las vanguardias terminaron por implosionar la vinculación entre élite, arte, belleza y teoría al cambiar por completo las pautas de realización y difusión.

¿De qué modo debe intervenir el Estado en la producción artística y cultural de una nación?, ¿qué marcas imprime esa intervención en los materiales?, ¿cómo se configura el nexo entre la dimensión política y la estética? Es sabido que la estrategia desplegada por el kirchnerismo en este nivel ha sido objeto de señalamientos esgrimidos en términos de la contradicción estereotipo-complejidad o esencialismo nacionalista-objetividad del pensamiento crítico y que lo mismo se le cuestionaba a la propuesta para el arte y la cultura de los primeros gobiernos peronistas. En este capítulo buscaremos, entonces, mirar desde el arte ese panorama y atender a un debate aún abierto: el del supuesto realismo estereotipado que caracterizó la factura de imágenes poéticas en estos períodos.

\section{Herencias}

Cuando se hace referencia a la estética del peronismo el lugar común es la mención a los libros de lectura para escuela primaria donde figuraba la leyenda «Mamá me mima, Evita me ama», la advertencia sobre el fuerte rechazo que producía en el gobierno el arte abstracto, el empeño en recordar la arenga "alpargatas sí, libros no» y la alusión a un proteccionismo de estilo fascista en torno a la producción artística y cultural que habría ido en detrimento del desarrollo de representaciones y propuestas más fértiles.

Sin embargo, durante el peronismo se desarrolló acaso el período más fructífero del cine entendido como un arte industrial, en contraste con la idea de obra 
única y original. Perón fue quien propició la gratuidad de los conservatorios, las escuelas de arte y las universidades dedicadas a su enseñanza. En esa década se dio el auge de las grandes orquestas de tango y el esplendor de exponentes relevantes de la música española, el jazz y la canción italiana. Se fundaron el Instituto del Folklore, la Orquesta de Música Popular y la Orquesta Sinfónica. La radio alcanzó su mayor popularidad con audiciones musicales, radioteatro de diversos tipos y programas dedicados al mundo del espectáculo. Se creó el Teatro Obrero Argentino de la CGT con un elenco constituido por obreros de distintos gremios. En 1948 se publicaron Adán Buenosayres (1948), de Leopoldo Marechal, La trama celeste, de Adolfo Bioy Casares y El túnel, de Ernesto Sábato. El 17 de octubre de 1951 tuvo lugar la primera emisión televisiva en el país. El Estado creó una Subsecretaría de Cultura y, bajo su órbita, una Junta Nacional de Intelectuales. Se subvencionaron 1600 bibliotecas populares, se organizaron programas de conferencias y audiciones y se impulsó un centro cultural itinerante -el Tren Cultural- que recorría el país para trasladar grupos de teatro, exposiciones, músicos y escritores (Fiorucci, 2008; Kriger, 2009; Leonardi, 2012; Lindemboim, 2013). La lista podría continuar.

Entonces, si se despoja el análisis del sesgo caricaturesco con el que ha sido reiteradamente formulado puede verse que la relación de este movimiento con el mundo del arte fue, cuanto menos, más compleja.

En lo que respecta a las artes visuales la idea de que la política artística del peronismo perseguía y negaba a las propuestas modernas ha sido revisada por trabajos recientes que sin negar las aristas controversiales del asunto escrutan ese presupuesto y reconocen en el período una articulación fluctuante de proyectos alternativos, tan provista de tensiones como de acuerdos y zonas de negociación.

Andrea Giunta (2001) señala que en esos años se articuló un programa artístico opuesto a aquél que podía reconocerse en la escena oficial y que ese proyecto se vinculó, de distintas formas, con el que se forjaba desde otros espacios de la cultura, como por ejemplo la revista Sur y, específicamente en el campo artístico, la revista Ver y Estimar, dirigida por Jorge Romero Brest. Según la autora, después de los primeros años de enfrentamiento el peronismo estableció un acuerdo 
tácito con esos sectores y para 1952 estos llegaron a ocupar un lugar privilegiado en las exposiciones oficiales, de las que participaron grupos abstractos geométricos como Madí y Perceptista. Giunta argumenta que la política artística del gobierno estuvo ceñida a las intervenciones de gestores particulares: «y así como Ivanissevich atacaba el arte abstracto, otros funcionarios como Ignacio Pirovano, director en ese momento del Museo de Arte Decorativo, lo defendía e incluso lo coleccionaba» (pp.67-68).

En la misma línea, Verónica Tejeiro (2017) sostiene que el posicionamiento del peronismo en el orden internacional de la posguerra - lo que conocemos como la «tercera posición»- ${ }^{12}$ trazó, en un primer momento, estrategias para regular la producción y la circulación de las imágenes con una tendencia hacia las representaciones figurativas de la cotidianeidad nacional, en busca de generar una nueva distribución de la cultura pero que la crisis económica de fines de los cuarenta, el Segundo Plan Quinquenal y la apertura hacia los capitales extranjeros redundaron en nuevos lineamientos en el ámbito de la cultura que llevaron a poner en valor al arte abstracto como carta de presentación ante el mundo.

Por lo tanto, debajo de la explicación cristalizada en el acecho de Ivanissevich a los artistas abstractos es posible encontrar interpretaciones que reponen otros matices y permiten distinguir contradicciones y transacciones fluctuantes en esos vínculos estéticos y políticos.

\footnotetext{
12 Un nacionalismo alejado tanto del liberalismo como del comunismo.
} 

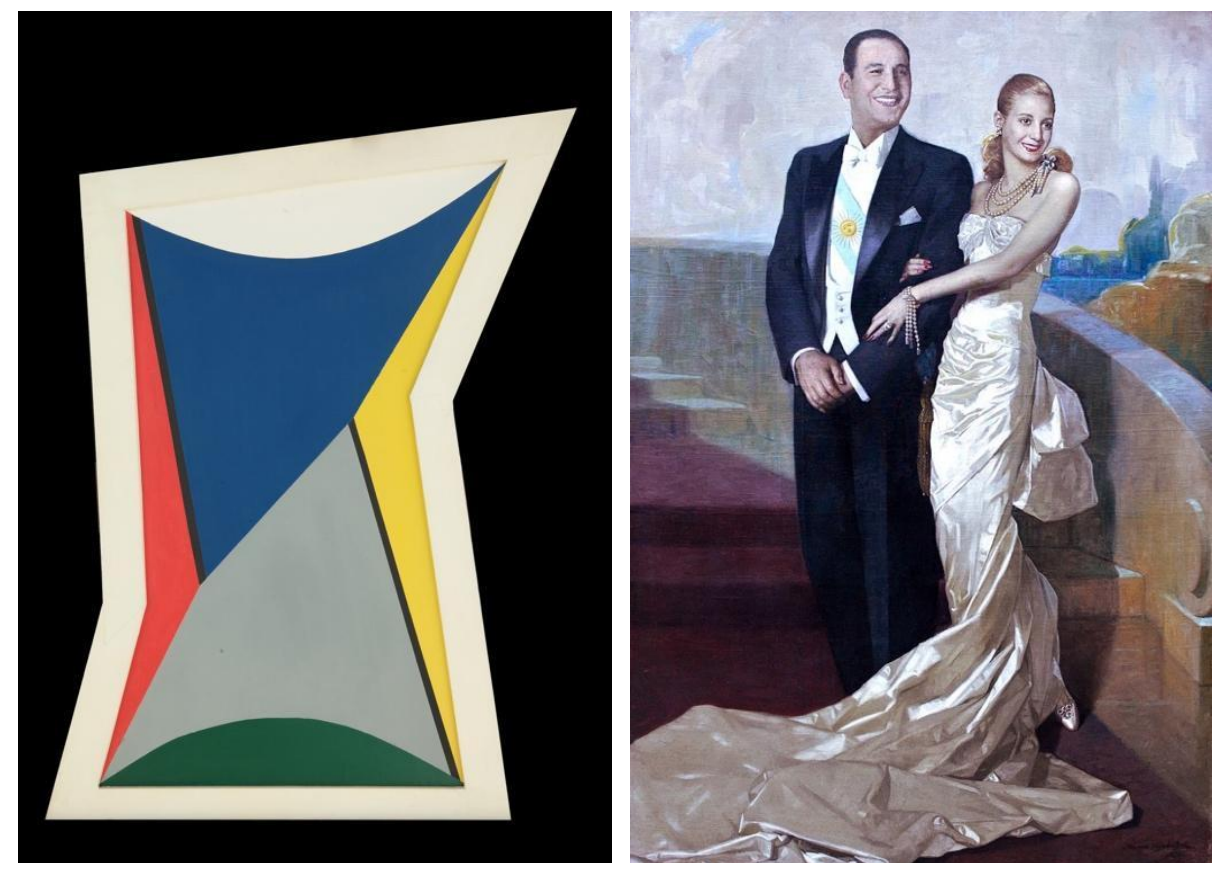

Retrato de Juan Domingo Perón y Eva Duarte (1948), por Numa Ayrinhac. Único retrato realizado a la pareja por pedido oficial

Pintura Madi A-3 (1946), de Gyula Kosice, integrante del movimiento Madí

Algo similar ocurre en el caso del cine. La hipótesis de que el exacerbado paternalismo peronista habría perjudicado de manera notable la producción cinematográfica al fomentar la corrupción y la competencia en el sector y al limitar las temáticas posibles para el despliegue de los guiones tuvo sus orígenes en la obra de Domingo Di Núbila, Historia del cine argentino (1959), tomada como referencia por buena parte de la bibliografía posterior sobre el tema.

En su libro Cine y Peronismo. El estado en escena (2009), Clara Kriger propone una relectura que contempla el modo en que esas medidas de protección entendidas como profundización de algo que había comenzado en los años treintadieron lugar al auge del cine argentino en la década $y$, sin desconocer la implementación de un control de contenidos mediante el apoyo crediticio, complejiza la mirada y atiende a las modificaciones de las políticas a lo largo del tiempo y a sus articulaciones con la situación internacional del cine para dilucidar pujas, acuerdos y reconfiguraciones. A su vez, confronta con cincuenta años de análisis en los que se catalogó a las producciones del período como meramente 
pasatistas o propagandísticas y diferencia, dentro de los productos cinematográficos, aquellos documentales tradicionales de publicidad estatal de un conjunto de ficciones en las que la elaboración de imágenes sobre el Estado no pueden definirse en términos de la divulgación partidaria.

Pero incluso en el plano específico de lo que podríamos catalogar como propaganda estética es posible impugnar algunos presupuestos. En su trabajo sobre las imágenes oficiales entre 1946 y 1955, Marcela Gené (2005) cuestiona las lecturas que equiparan las estrategias de autorrepresentación peronistas con las del nazismo o el fascismo y encuentra mayores puntos de contacto entre aquellas y las producciones gráficas norteamericanas del New Deal o de la Unión Soviética revolucionaria, fundamentalmente en lo que atañe a ubicar el ideal del progreso en la figura del trabajador de la industria. A partir del análisis de un conjunto de afiches publicitarios la autora detecta en la gráfica peronista una herencia múltiple, que desterró la hegemonía de los arquetipos republicanos hasta entonces vigentes y ubicó en su lugar a los hombres y a las mujeres de la clase obrera, los principales beneficiarios de los derechos sociales garantizados por el Estado.

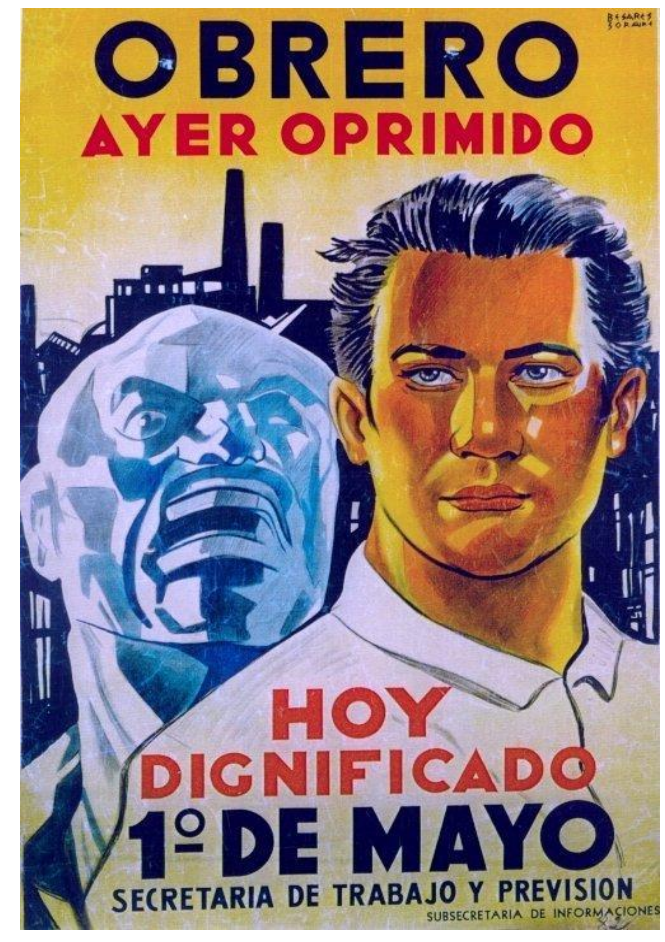

Afiche de la Subsecretaría de Informaciones. Fuente Instituto Nacional Juan Domingo Perón 
De cualquier manera, sin dudas la asociación peronismo/populismo/realismo social/sobre-argumentación como contracara de la cadena antiperonismo/libertad/vanguardia/abstracción encuentra su límite más claro en la literatura y, particularmente, en la escritura vinculada al tango, que fue el emergente poético más importante del nuevo sujeto social surgido tras la segunda migración y consolidado como base política del movimiento. Dice Gustavo Varela (2007):

El río de la procesión fúnebre que conduce los restos de Gardel del Luna Park al cementerio de la Chacarita invierte su curso y llega en octubre de 1945 a la Plaza de Mayo. Son los mismos que caminan Corrientes abajo lo que había sido hacia arriba: muerte y nacimiento, un dios desterrado y otro que llega. Para los dos, la misma sonrisa, amplia, poseedora, las manos abiertas, la cara enorme; una vela encendida, la estampita en la sala y una rama de olivo bendecida, atravesándola. Ocho años después parece que alguien, al fin, va a pitar el cigarrillo (s.p).

Durante el peronismo, el tango literario terminó de consolidarse como la música popular del Río de La Plata (Belinche, 1993). Allí se dio una fusión entre la cultura migrante, el arte burgués popular (la ópera), las mutaciones lingüísticas (el lunfardo, los equívocos impostados), el bandoneón, los criollismos, las interpenetraciones del arte clásico (la orquesta) y una originalidad cultivada aún en los mayores exponentes del anti peronismo, entre ellos, Borges y Piazzolla.

Desde Macedonio Fernández, pasando por Leopoldo Marechal, los escritores de FORJA y los grandes letristas como Cátulo Castillo, Homero Manzi, los hermanos Expósito y Enrique Santos Discépolo hasta el ocaso producido por la persecución y los cambios después de la Segunda Guerra Mundial con la aparición de una música para los jóvenes, el rock, tuvo lugar un movimiento que, según sostiene José Pablo Feinmann (Canal Encuentro, 2016 a) es un milagro y que difícilmente pueda asociarse a un realismo de fetiche nacionalista y explícito. De hecho, tal como ocurre con el flamenco o con el primer blues, con pobres y escasos intentos aislados, no hubo un tango de protesta, como no hubo un cante jondo de protesta. La protesta está en el desgarramiento de la voz, en el empleo de sonidos rotos y sucios y en orquestaciones originales que, paulatinamente, fueron convirtiendo a estos géneros de origen 
popular, de acuerdo a Diego Fischernam (2013), en músicas abstractas, en músicas para escuchar.

Entonces, la distancia entre la riqueza de estas manifestaciones y el análisis de los sectores enfrentados a la política cultural de esos gobiernos es tan amplia como la variedad de metáforas tangueras escritas en la década. Los ejemplos son incontables y escasamente literales: "Sur, una luz de almacén. Ya nunca me verás como me vieras, recostado en la vidriera esperándote» (Manzi \& Troilo, 1948); «Estercita y Mimí como Ninón, dejando sus destinos de percal, vistieron al final mortajas de rayón, al eco funeral de tu canción» (Manzi \& Troilo, 1949); "Ya da la noche a la cancel su piel de ojera. Ya moja el aire su pincel y hace con él la primavera. ¡Pero qué! Si están tus cosas pero tú no estás, porque eres algo para todos ya, como un desnudo de vidriera» (Expósito y Stampone, 1955); O «Dónde estaba dios cuando te fuiste» (Discépolo,1945) pregunta asimilable a algunos de los interrogantes planteados por la Escuela de Frankfurt en esos mismos años, en el período correspondiente al exilio y al auge del nazismo, a partir del cual Adorno llegó a plantear que después de Auschwitz ya no podía haber poesía.

Ese desencantamiento, que por cierto debatía con la razón iluminista y al mismo tiempo renegaba de la incipiente industria cultural, es rastreable también en gran parte de la producción del tango de la década del 40 y del 50. Del mismo modo en que el marxismo y el socialismo centroeuropeo y, fundamentalmente alemán, pasaron de la confianza extrema en la revolución a la derrota de los sectores de izquierda y a la irrupción del nazismo, el tango metaforizó el desaliento de esos migrantes que venían a Argentina a hacer la América y se encontraron con la década infame, con el cierre de los frigoríficos, con la caída del modelo agroexportador.

Se podría decir que el tango del período peronista encontró sus materiales en la década anterior y los convirtió en poética. Expresó de muchas maneras la pérdida de la ilusión, la patria ausente, la expectativa perdida concentrada en la pena. Y como sostiene Feinmann (Canal Encuentro, 2016 a), se planteó preguntas metafísicas: qué es la muerte, qué es dios, qué es el amor. 


\section{La batalla}

Las propiedades de los contornos entre gestión estatal y producción artística y cultural para el caso de los gobiernos de Néstor Kirchner y de Cristina Fernández han sido abordadas en estudios recientes a partir de un conjunto de transformaciones que, según diferentes autores (Bavala y Suárez, 2016; Lacarrieu y Cerdeira, 2016; Zamorano, 2016; Segura y Prato, 2018; Fernández, 2020), implicaron, en cierto sentido, una democratización del acceso al arte y a la cultura y una ampliación de los derechos culturales. Repasemos algunas.

En el transcurso de los tres gobiernos kirchneristas hubo cuatro funcionarios al frente de la cartera de Cultura. Después de una fugaz primera administración a cargo de Torcuato Di Tella, en 2004 asumió el politólogo José Nun, quien se mantuvo en el cargo hasta la derrota electoral en las elecciones legislativas de 2009 y puso en funcionamiento algunos de los lineamientos principales para el sector, luego consolidados en las gestiones de Jorge Coscia (2009-2014) y Teresa Parodi (20142015).

Durante esos primeros años se planteó como cuestión fundamental la construcción y el análisis de datos sobre el área. Por lo tanto, en 2006 se crearon el Sistema de Información Cultural de la Argentina (SINCA), con el objetivo de reunir información acerca de perfiles de consumo en las distintas regiones del país, y el Sistema de Información Cultural del Mercosur (SICSUR), cuya misión fue recoger y sistematizar indicadores culturales de todos los países de la región. A su vez, se impulsaron programas federales como Libros y Casas - luego replicado en Cuba y en Chile- para garantizar y extender el acceso a la lectura, y Café Cultura, mediante el cual se organizaron charlas-debate con intelectuales y artistas que discutieron en torno a la cultura en universidades, cárceles y otros espacios de todo el país.

A la continuidad de esas políticas se añadió, en los años posteriores, una importante inversión en infraestructura. Fueron inaugurados el Museo del Libro y de la lengua (2011), el Museo del Bicentenario (2011) y el Museo Malvinas e Islas del Atlántico Sur (2014), ubicado en el Espacio para la Memoria y Derechos Humanos (Ex 
ESMA).$^{13}$ Se remodeló el Museo Nacional de Bellas Artes. En Santiago del Estero se restauró la antigua Casa de Gobierno para dar apertura al Centro Cultural del Bicentenario (2010), un complejo que contiene tres museos. En Resistencia (Chaco) se fundó la Casa de las Culturas (2010), en San Juan el Museo de Bellas Artes (2011), en Mendoza el Centro Cultural Julio Le Parc (2012), entre otros. ${ }^{14}$ Se montaron estructuras complejas para la realización de los festejos del Bicentenario en 2010. Tecnópolis, la muestra de arte, ciencia, industria y tecnología por la que circularon millones de personas, comenzó a funcionar en 2011 convirtiéndose rápidamente en una pieza clave del dispositivo cultural promovido por el kirchnerismo. Y en 2015, como una de las últimas grandes apuestas del gobierno de Cristina Fernández, en las instalaciones del antiguo Palacio de Correos se construyó el CCK, el centro cultural más grande de América Latina y el tercero a nivel mundial, con sus nueve pisos, sus cuarenta y siete salas de exposiciones, sus dieciséis salas de ensayos, sus seis auditorios multimedia, su auditorio de cámara y su sala sinfónica, la «Ballena azul», como principal vedette.

En lo que respecta al impulso del mercado interno, al fomento de las industrias culturales y artísticas y a la regulación de derechos laborales, se aprobaron la Ley Nacional de la Música y la Ley del Actor, ${ }^{15}$ el INCAA recuperó su dinamismo como soporte de la producción cinematográfica, se estableció una cuota de pantalla mínima de películas nacionales a ser exhibidas en los auditorios argentinos y se otorgaron subsidios a productores audiovisuales locales. Se creó el Mercado de

\footnotetext{
${ }^{13}$ El espacio se constituyó como una suerte de complejo de la memoria que albergó también a la Casa de la Militancia de H.I.J.O.S., al Centro Cultural de la Memoria Haroldo Conti, a la Casa por la identidad, al Archivo Nacional de la Memoria, al Centro Internacional de Educación en Derechos Humanos de la UNESCO, al EcuNHi, a la Asociación Madres de Plaza de Mayo, a Familiares de Desaparecidos y Detenidos por Razones Políticas, a la I.L.I.D., al Instituto de Políticas Públicas de Derechos Humanos del MERCOSUR, a Madres de Plaza de Mayo Línea Fundadora, a Memoria Abierta y a Canal Encuentro.

${ }^{14}$ En esa línea, en el año 2010 se puso en marcha la construcción, ampliación y/o refacción de las llamadas Casas del Bicentenario, lugares distribuidos en todo el país y destinados al desarrollo de actividades culturales, educativas, artísticas y recreativas y a la exposición permanente de elementos identitarios a nivel local y federal.

${ }^{15}$ Hay que mencionar también que quedaron pendientes otras regulaciones significativas como la Ley de la Danza y que buena parte de estos sectores permanecieron en condiciones laborales de informalidad.
} 
Industrias Culturales Argentinas (MICA), con el fin de visibilizar e impulsar la producción audiovisual, musical, de artes escénicas, editorial, de diseño y de videojuegos en todo el territorio. En vistas a impulsar los intercambios regionales, en 2015 se llevó a cabo la primera edición del Mercado de Industrias Culturales del Sur (MICSUR) que reunió a artistas, productores, empresarios y funcionarios culturales de Argentina, Brasil, Colombia, Chile, Ecuador, Venezuela, Perú, Bolivia, Uruguay y Paraguay.

Por otro lado, con las particularidades de cada gestión, los gobiernos kirchneristas se identificaron por operar sobre la política de medios vigente. Tal como distinguen Martín Becerra y Guillermo Mastrini (2016), luego de un primer período orientado al salvataje de las empresas mediáticas en crisis, los esfuerzos se centraron en crear nuevas señales con un perfil cultural y educativo (Canal Encuentro, PakaPaka, IncaaTV, DeporTV, TecnópolisTV), en disputar el rating, en fomentar el papel del Estado como emisor y en fortalecer la capacidad de las productoras locales de contenidos.

En ese sentido, dos puntos clave fueron la sanción de la Ley de Servicios de Comunicación Audiovisual (26.522) y la creación del Sistema Argentino de Televisión Digital Terrestre, ambas medidas promulgadas en 2009. La iniciativa de desarrollar, en un plazo de diez años y mediante un sistema gratuito, la transición de la televisión analógica a la digital para emitir y recepcionar señales digitales terrestres incluyó la construcción de torres de transmisión a lo ancho y a lo largo del país y el reparto de alrededor de un millón de decodificadores. El Decreto $1148 / 2009$, que señala el abandono de la norma norteamericana ATSC (adoptada durante el menemismo) y su reemplazo por el estándar japonés-brasilero ISDB-Tb, fue anunciado por Cristina Fernández en un acto realizado en Bariloche junto a Lula Da Silva, y respondió a una política estratégica del bloque regional.

En la misma línea, la Ley de Servicios de Comunicación Audiovisual, aún con las dificultades que comportó su implementación, buscó promover el federalismo, la incorporación de actores sin fines de lucro, universidades y pueblos originarios y la producción nacional de contenidos, al tiempo que estableció límites para la 
concentración de los mercados mediáticos y colocó los derechos a la comunicación y a la cultura en un lugar central en la agenda pública. Los puntos medulares de la Ley se inspiraron en elaboraciones y debates previos de la sociedad civil que fueron incorporados a la agenda política a partir de 2008, cuando el gobierno de Cristina Fernández ubicó la cuestión de los medios en el centro de su discurso, como correlato del conflicto con las patronales agropecuarias y con el grupo Clarín. ${ }^{16}$

Con el recrudecimiento de esa crisis como marco despuntaron, tal vez, las notas más distintivas de aquello que el propio kirchnerismo definió como batalla cultural, desplegada en una redefinición del vínculo entre política, arte y cultura a partir del tejido conjunto entre el gobierno y determinados colectivos y actores externos.

En primer lugar, la aparición de programas como 6,7,8 y Duro de Domar y las características que adoptaron las líneas editoriales de diarios como Página 12 y Tiempo Argentino permitieron delinear la embestida simbólica en torno a dos ejes. Por un lado, la denuncia de manipulación mediática - «Clarín miente»-y, por otro, la puesta en valor de imágenes hasta entonces veladas: las plazas masivas, la presencia de artistas y personalidades de la cultura afines a las medidas del gobierno, el vínculo estrecho con distintos presidentes latinoamericanos, la difusión de políticas como la estatización de las AFJP, la Asignación Universal por Hijo y la nacionalización de YPF y de Aerolíneas Argentinas, por nombrar algunas. Al margen del oficialismo sobreactuado de algunos personajes y de la repetición hasta el hartazgo de ciertas consignas, en estos ámbitos la contienda alcanzó sus puntos más profundos.

En segundo lugar, fue el tiempo de esplendor de algunas de las estrategias visuales, musicales y audiovisuales que dieron lugar a lo que, si se fuerza bastante la holgura terminológica, puede ser reunido bajo el mote de «estética kirchnerista». En

\footnotetext{
${ }^{16}$ Frente a la decisión del gobierno argentino de incrementar las retenciones a las exportaciones de soja y girasol y establecer un sistema móvil para determinar su valor, el sector agropecuario organizó un paro con cortes de rutas y manifestaciones multitudinarias en la capital federal. La medida derivó en un conflicto extenso que culminó con la derogación de la Resolución 125/08.
} 
los próximos capítulos nos detendremos en algunas de ellas, como los festejos del Bicentenario, con sus desfiles callejeros, sus recitales masivos y sus números de alto impacto y complejidad poética presenciados por multitudes o la apuesta a producciones televisivas como La asombrosa excursión de Zamba, que propuso un acercamiento disruptivo al relato de la historia nacional para el público infantil. También nos referimos a la emisión de nuevas series de billetes que alteraron el panteón de próceres propuesto por la colección monetaria vigente, a partir de la incorporación de Eva Perón ${ }^{17}$ y de las Madres y Abuelas de Plaza de Mayo ${ }^{18}$ en los billetes de 100 pesos, de Juana Azurduy y Pedro Ríos en el reverso del Belgrano de $\$ 10^{19}$ y de las Islas Malvinas ${ }^{20}$ para los billetes de 50 , con la representación del gaucho Antonio Rivero -el escasamente recordado primer defensor de la soberanía argentina en las Islas contra el imperialismo en 1833-, del Buque ARA General Belgrano hundido ilegalmente por las flotas inglesas durante la guerra de 1982 y del Cementerio Darwin donde yacen los caídos en combate.

\footnotetext{
${ }^{17}$ El billete con la imagen de Eva fue lanzado en 2012 a partir de la recuperación de un proyecto del primer peronismo que había sido escondido por los empleados de la casa de la moneda durante la proscripción del movimiento. Por primera vez en la historia nacional se incorporó la representación de una mujer en la emisión monetaria (Sarmiento, 2016).

${ }^{18}$ En marzo de 2015, en un acto realizado en el Salón Mujeres Argentinas de Casa de Gobierno, Cristina Fernández dio a conocer el boceto de este billete en el que de un lado puede verse el perfil de una mujer con su pañuelo blanco y, del otro, se muestra la emblemática ronda de las Madres en Plaza de Mayo sobre un fondo en el que aparecen los códigos genéticos que permiten las identificaciones de las compañeras y los compañeros desaparecidos durante el terrorismo de Estado.

${ }^{19}$ Este nuevo diseño fue mostrado públicamente por la ex presidenta el 20 de junio de 2014, durante el acto en el Monumento Nacional a la Bandera, en Rosario.

${ }^{20}$ Fue presentado el 2 de abril de 2014, en la conmemoración número 23 de la guerra de Malvinas.
} 

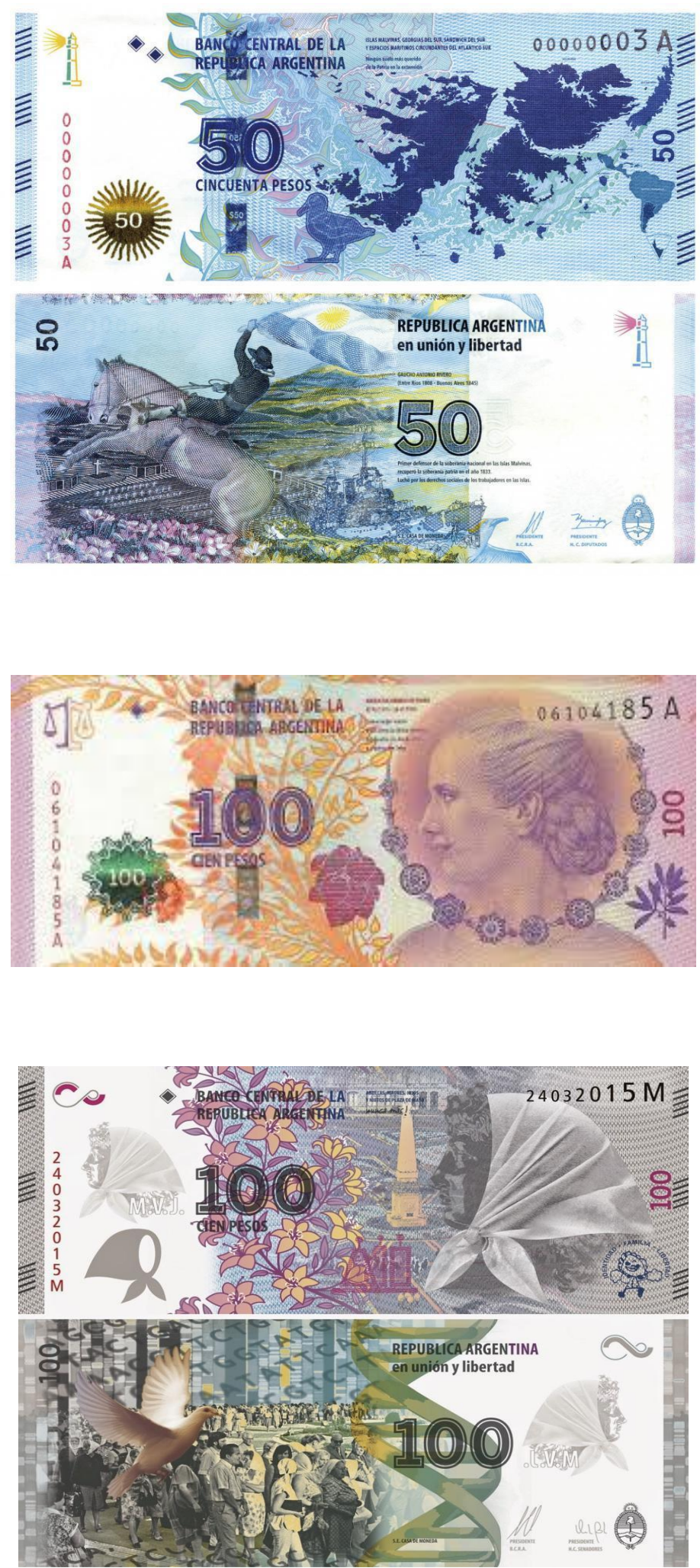


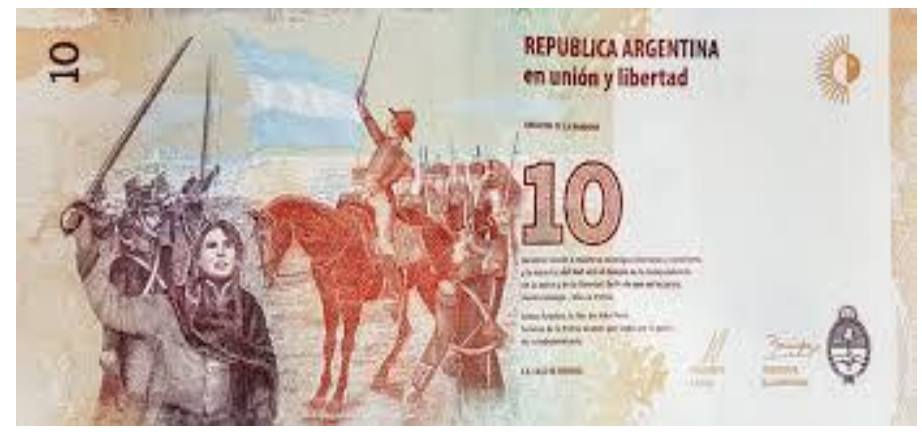

Rediseño de billetes de $\$ 50, \$ 100$ y $\$ 10$

Del mismo modo, podemos registrar la sustitución de unas imágenes por otras, como ocurrió con el desplazamiento, en el patio trasero de la Casa Rosada, de la estatua de Cristóbal Colón - un regalo de la colectividad italiana con motivo del centenario de la Revolución de Mayo de 1810- y su reemplazo por una escultura de la heroína de la independencia Juana Azurduy — donada por el Estado Plurinacional de Bolivia- (Sarmiento 2016). El recuerdo de las palabras casi curatoriales que la presidenta dedicó al asunto permite conjeturar que ese relevo entrañó más de un reborde metafórico:

A mí me encanta el Salón de las Mujeres del Bicentenario. Además, ahora la tengo a la Juana que me está mirando por las ventanas, a la Juana Azurduy, ya van a ver. Modifiqué la ventana para que la Juana quede a la altura y se pueda ver. Ella está mirando y con la espada en alto, no en la mano derecha, que es la de matar, sino en la mano izquierda, que es la de conducir y señalar un camino, nada más y mirando a la Casa Rosada y mirando hacia adentro, al interior. Porque podrá parecer una distinción demasiado sofisticada, pero el que estaba antes, don Cristóbal Colón, señalaba con su mano hacia afuera, hacia Europa, estaba parado en el medio de la plaza, de espaldas a la Argentina y señalando con el dedo hacia afuera. Juana mira a la Casa Rosada, mira al continente, mira a los argentinos y está señalándonos a nosotros. No es una cuestión menor. Así que, el que se siente ahí, que se acuerde que va a tener a la Juana mirándolo (Casa Rosada Presidencia, 2015).

Por último, a esa revisión del repertorio de íconos, a la incorporación en el espacio urbano de esculturas, murales y otros homenajes perdurables, a la factura de un imaginario a partir del rescate de un conjunto de imágenes y a la disputa 
simbólica por la posesión de la verdad se sumó el nacimiento del colectivo cultural Carta Abierta, cuya posición con respecto al gobierno nacional fue mutando de una postura inicial de apoyo crítico a una de mayor organicidad (González, 2012). Sus intervenciones en el debate público dieron cuerpo a una estructura argumental en la que se amalgamaron las trayectorias militantes de sus miembros, con afluentes nacional-populares y de izquierdas democráticas, para dar lugar a una caracterización del kirchnerismo que podríamos esquematizar en algunos puntos: el retorno de la política después del "que se vayan todos», la ruptura con el pasado específicamente con el neoliberalismo-, una definición de la democracia estrechamente vinculada a la idea de justicia social propia del peronismo, el rescate de los emblemas de la generación más castigada por el terrorismo de Estado y la restitución de una idea de soberanía nacional. La invocación a Walsh en el nombre mismo del colectivo colaboró, probablemente, a ceñir su horizonte de articulación entre trabajo intelectual y militancia política (Retamozo, 2012).

Del lado de las oposiciones, valiéndose de sus múltiples brazos en la prensa gráfica y en la pantalla chica, el multimedios Clarín funcionó como principal epicentro de un discurso antikirchnerista que se desplegó desde los cuestionamientos puntuales en editoriales y programas periodísticos hasta los contenidos abordados en producciones de ficción como El puntero, la serie protagonizada por Julio Chávez que mostraba el entramado de corrupción en la cotidianeidad política de un barrio del conurbano bonaerense, con claras alusiones al universo simbólico del partido justicialista y al gobierno, como por ejemplo la decisión de que uno de los protagonistas lleve puesta una remera con la estampa del Nestornauta, el personaje que se convirtió en bandera para la militancia $k$ después de la muerte de Néstor Kirchner.

Esa retórica se completó y buscó interpelar a públicos heterogéneos gracias a la colaboración de otros actores entre los que podríamos mencionar a los periódicos La Nación y Perfil, a las revistas Ñ y Noticias, a periodistas como Jorge Lanata y Luis Majul, a conductoras como Mirtha Legrand o Mariana Fabbiani y a un conjunto de intelectuales y personalidades de la cultura, muchas de las cuales se nuclearon en 
grupos como Aurora - constituido por adherentes a la UCR - o como Plataforma

2012, conformado en vistas a la publicación del documento que se tituló «Plataforma para la recuperación del pensamiento crítico ${ }^{21}$ y que instaba a sus lectores a escapar del efecto impositivo del relato hegemónico, a desconfiar de su épica y a desenmascarar sus ocultamientos.

Demorémonos un momento en esa categoría, la de relato. Por definición, un relato es una construcción que puede adaptarse a diferentes tipologías discursivas. Como género literario no comporta una estructura determinable sino más bien una modalidad centrada en la síntesis de los datos nodales que envuelve una historia.

El uso de la lengua, se sabe, excede a los términos. El relato, o lo que llamamos así en la actualidad, se encuentra en estado de mutación permanente como todas las formas lingüísticas. Mijaíl Bajtín (1979), el gran teorizador de estos asuntos plantea:

Los cambios históricos en los estilos de la lengua están indisolublemente vinculados a los cambios de los géneros discursivos [...]. Cualquier extensión literaria por cuenta de diferentes estratos extraliterarios de la lengua nacional está relacionada inevitablemente con la penetración, en todos los géneros, de la lengua literaria (géneros literarios, científicos, periodísticos, de conversación), de los nuevos procedimientos genéricos para estructurar una totalidad discursiva, para concluirla, para tomar en cuenta al oyente o participante, etc., todo lo cual lleva a una mayor o menor restructuración y renovación de los géneros discursivos. Al acudir a los correspondientes estratos no literarios de la lengua nacional, se recurre inevitablemente a los géneros discursivos en los que se realizan los estratos. En su mayoría, éstos son diferentes tipos de géneros dialógico-coloquiales; de ahí resulta una dialogización, más o menos marcada, de los géneros secundarios, una debilitación de su composición monológica, una nueva percepción del oyente como participante de la plática, así como aparecen nuevas formas de concluir la totalidad, etc. Donde existe un estilo, existe un género. La transición de un estilo de un género a otro no solo cambia la entonación del estilo en las condiciones de un género que no le es propio, sino que destruye o renueva el género mismo (p. 251).

${ }^{21} \mathrm{El}$ documento fue firmado por artistas e intelectuales como Beatriz Sarlo, Lucrecia Martel, Diana Kordon, Roberto Gargarella, Luis Felipe Noe, Guillermo Saccomano, Maristella Svampa, Norma Giarraca y Osvaldo Tcherkaski, entre muchos otros. En los días posteriores a su publicación, algunos integrantes como Saccomanno y Giarraca difundieron el retiro de su adhesión debido a la carga simbólica que representaba la presencia de Sarlo entre los firmantes. 
¿Es el llamado relato kirchnerista una suerte de género específico del lenguaje político al estilo de la época? ¿Recoge tal vez las tradiciones del populismo en el sentido que lo concibe Ernesto Laclau? ${ }^{22}$

En ciertas versiones muy en boga sobre el storytelling («contar una historia») ${ }^{23}$ y su función ideológica, el término ha sido apropiado por corrientes del liberalismo con una doble entrada complementaria: en un caso el relato es interpretado como un pretendido embellecimiento artificial que distorsiona la visión objetiva de los hechos e intenta convencer al espectador enfatizando las virtudes de un producto. ${ }^{24}$ Desde tal óptica, el sector político nucleado en el macrismo ${ }^{25}$ le ha otorgado a esta palabra una dimensión casi de estilo para referir al carácter engañoso del discurso kirchnerista, epíteto adoptado incluso para señalar a actores que no cuadran de manera absoluta en esa línea política.

El otro empleo del concepto, cercano pero distinguible, alude a su tradición literaria, a sus artificios y, en este caso, al relato ficcional deliberadamente sombrío, que deja siempre una zona sin develar y que, en la utilización de los sectores referidos

\footnotetext{
${ }^{22}$ Sin ánimos de simplificar la teoría de Laclau ni de extendernos en ella aquí de un modo exhaustivo recordemos que, en términos muy generales, en su obra el populismo es concebido como una lógica política cuya base se constituye con la elaboración de un sistema estable de sentidos colectivos capaces de movilizar a los grupos que los demandan. Supone la construcción de una identidad popular generada por las exclusiones sociales que el sistema produce e implica una expansión de la cadena de equivalencias y una articulación simbólica que ofrece intentos de sutura de la diversidad (Laclau, 2006). Para profundizar sobre este asunto ver: Retamozo, M. (2017). La teoría del populismo de Ernesto Laclau: una introducción. Estudios políticos, (41), 157-184.

${ }^{23}$ Es un término habitual en el marketing, el mundo empresarial y los cursos de liderazgo de las empresas que pretenden instalar determinadas marcas.

${ }^{24}$ Podría ejemplificarse en la actualidad con la desconfianza sobre las bondades de la vacuna contra el COVID 19 y el supuesto ocultamiento de sus contradicciones o aspectos cuestionables.

${ }^{25}$ El macrismo es una fuerza política de centro derecha, surgida en 2003 en torno a las experiencias de gobierno de Mauricio Macri al frente de la Ciudad Autónoma de Buenos Aires, que se nucleó en el el partido Propuesta Republicana (PRO) y en 2015 logró el triunfo electoral en Argentina a partir de la conformación de la alianza Cambiemos, una coalición política constituida por el acuerdo entre Mauricio Macri (del PRO), Elisa Carrió (de la Coalición Cívica ARI), y Ernesto Sanz (de la Unión Cívica Radical) y el acompañamiento del Partido Fe, el Partido Demócrata Progresista, el Partido Conservador Popular y el Partido del Diálogo.
} 
también se contradice con la esquiva noción de verdad. Aquí, el relato se entiende como lo contrario a la transparencia, a su vez, sinónimo de honestidad y ética. ${ }^{26}$

Estas puntualizaciones nos devuelven a las preguntas iniciales acerca de la estetización de la política y la politización del arte y de la cultura. Sostengamos como premisa que, de algún modo, cada período replantea definiciones en torno a lo bello y lo feo, lo bueno y lo malo, lo verdadero y lo falso (Zátonyi, 2007). No existe un arte no político o una cultura apolítica sino que lo que cambia es el nivel de explicitación de esa politicidad. La forma no es neutral y es la forma, justamente, lo que define la experiencia estética.

Es innegable que el kirchnerismo libró su batalla y que empleó en ella una variedad importante de municiones. Sin embargo, algunos rastros nos conducen a sondear más hondamente la supuesta cristalización unívoca de esos suministros. Podríamos mencionar como indicios, por ejemplo, las entrevistas de Canal Encuentro ${ }^{27}$ y de la TV pública a figuras insospechadas de populismo como Marta Minujin, una de las principales exponentes del Instituto Di Tella, las biografías de Piazzola, un antiperonista radicalizado o el apoyo mediante subsidios a cineastas como Lucrecia Martel, quien manifestó públicamente más de una vez sus críticas al gobierno. Pero no queremos en este punto realizar un análisis de índole sociológico sino formal y estético.

\footnotetext{
${ }^{26} \mathrm{Al}$ respecto, en su análisis sobre la identidad política del partido Propuesta Republicana (PRO), Nicolás Schuttenberg (2017) señala: «para el PRO los viejos relatos y consignas como felicidad del pueblo, grandeza de la nación, justicia social, independencia económica, soberanía política, inclusión, república, democracia, igualdad de oportunidades, etc., no eran otra cosa que arengas para obtener poder» (p.141).

${ }^{27}$ Aquí merecen un comentario especial las entrevistas realizadas en el programa Encuentro en el estudio - conducido por Lalo Mir y promocionado como uno de los platos fuertes de Canal Encuentro desde 2009-. Esos diálogos responden a un formato donde la estética escapa al lenguaje televisivo o a aquello que ha sido denominado peyorativamente como panfletario. Más bien gravita un clima de intimidad, a menudo introspectivo, con largos momentos de silencio donde nada parece apresurado. A veces, el entrevistador participa de la obra con el entrevistado y hasta incluso con el televidente rompiendo, en cierto modo, lo que podríamos traducir como la cuarta pared. Esto ocurre, además, con obras que en sí mismas implican una búsqueda formal.
} 
En el ciclo de clases de José Pablo Feinmman, Filosofía aquí y ahora transmitido por Canal Encuentro a partir de 2008-, la pantalla muestra una disposición que si bien ha sido empleada en otros casos adquiere en esta secuencia un carácter estructural por la utilización a pleno de recursos de la retórica visual y audiovisual. El más notable es que el disertante, Feinmman, aparece en un espacio límbico parado casi siempre sobre ninguna parte como una figura realista en el interior de un cómic. Cambia de tamaño, se vuelve un sujeto mínimo en una suerte de plataforma virtual que, en muros y paredes también virtuales, va remarcando con grafitis y con animaciones ciertas palabras que adquieren nivel formal, por ejemplo, cuando el autor dice Revolución Rusa las letras se vuelven rojas o cuando menciona los tangos de Discépolo, estos parecen surgir del rostro caricaturizado del compositor. Feinmann, con su gestualidad florida y su dramatización casi actoral interactúa con esas animaciones y de pronto parece dar una clase, pero está siempre sostenido en la nada. El uso de la escala, la hipérbole, la metáfora, la metonimia, la elipsis, la cita intertextual y el empleo de una tipografía que remeda lo manual, la escritura de los cuadernos de la infancia, son tan determinantes como el nivel de síntesis que el filósofo conquista, en muchos pasajes, con maestría. Las ilustraciones estuvieron a cargo del dibujante Miguel Rep y fueron una marca distintiva de los programas, bastante lejana a la predictibilidad.

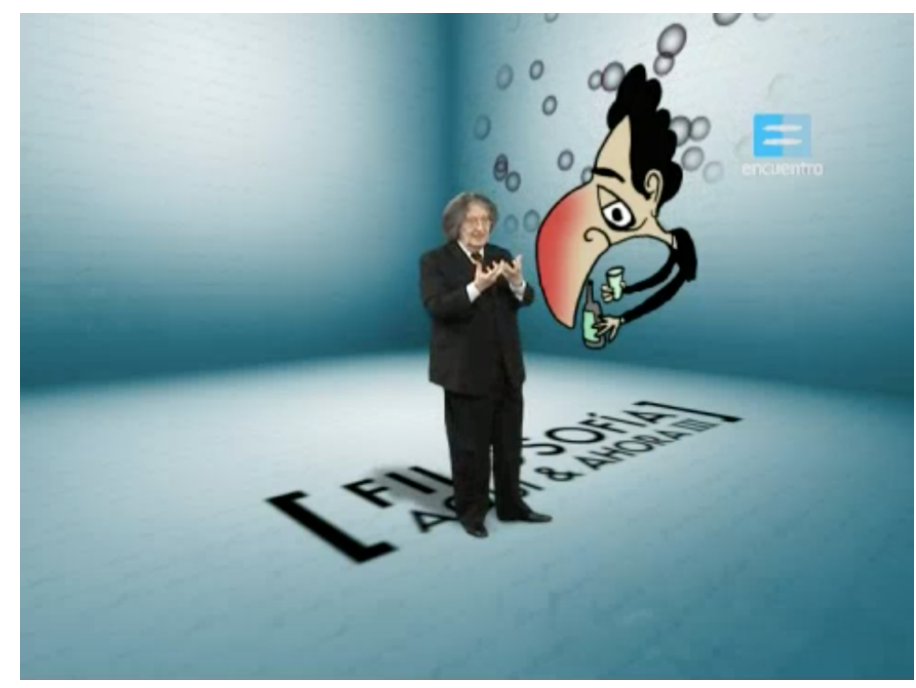

Fotograma de Filosofía aquí y ahora, Canal Encuentro 
En el caso de las conferencias que realizó Piglia ${ }^{28}$ sobre la historia de la novela argentina y sobre Borges, a diferencia de lo analizado en Feinmann, la escena simula una clase en lo que podría ser el auditorio de cualquier facultad. Hay una primera parte en la cual Piglia expone y otro tramo en el que, en una suerte de living, recibe a dos invitados que son especialistas en alguno de los temas abordados en el programa. La trama se construye con fragmentos filmados, por ejemplo, cuando se analiza Los siete locos, de Roberto Arlt (1929), la reflexión es recompensada con un fragmento de la película homónima en la que actúa Alfredo Alcón. ${ }^{29}$ El mismo Piglia se permite algunas actuaciones y conjuga sapiencia con humor en un tono casi siempre más interrogativo que asertivo, burlándose a menudo de sí mismo, como cuando relata las desopilantes entrevistas que tuvo con Borges y genera en su mismo relato una ficción. También es relevante el empleo de lo sonoro. La música se encuadra dentro de lo que muy genéricamente podría llamarse música contemporánea, es atonal y cumple de manera ambigua dos facetas: introduce y clausura, al tiempo que comporta un grado de exigencia para con el espectador.

Si vinculamos los dos programas, que tienen formatos diferentes, es posible, sin embargo, encontrar un elemento común en la impronta de sus protagonistas: la fluidez con que ambos tramitan el vaivén entre lo que muy genéricamente podríamos denominar como «lenguaje académico culto» y el guiño hacia un público no erudito. Este gesto es desarrollado por ellos en otras obras, como Las tres vanguardias (2019) -donde Piglia analiza a Saer, Puig y Walsh, estableciendo tres estrategias distintas para abordar la originalidad y, sobre todo, qué hacer con las masas en el ámbito literario- o La filosofía y el barro de la historia (2008)-libro en el que Feinmann recorre los grandes problemas filosóficos y a sus pensadores con claridad pedagógica y sin simplificaciones-. Los dos pasan con soltura de un léxico específico a uno

\footnotetext{
${ }^{28}$ Aludimos a los ciclos Escenas de la novela argentina (2012) y Borges por Piglia (2013), coproducidos por la Biblioteca Nacional y la Televisión Pública.

${ }^{29}$ Nos referimos al largometraje Los siete locos, dirigido por Leopoldo Torre Nilsson y protagonizado por Alfredo Alcón, Norma Aleandro, Thelma Biral, Héctor Alterio y Sergio Renán.
} 
absolutamente coloquial. Piglia describe las diferencias entre Flaubert y Sarmiento o abunda sobre la cuestión de las vanguardias y las neo vanguardias pero en el mismo segmento del programa remeda con gracia sutil anécdotas como aquella en la que Vargas Llosa va de visita a la casa de Borges:

\begin{abstract}
Vargas Llosa estaba hablando con él y le dice "Borges ¿cómo puede ser que usted viva en este departamento", porque Borges, efectivamente, vivía en un departamento muy modesto que algunos de nosotros conocemos, un departamento de tres ambientes, donde había goteras, había una palangana y caía una gota. Y Borges estaba lo más tranquilo, tenía una piecita ahí. Entonces, Borges se levantó y le dijo: "Bueno, que le vaya muy bien. Los caballeros argentinos no hacemos alarde" [...] Y al día siguiente Borges dice: "Vino un peruano que debe trabajar en una inmobiliaria, porque quería que me mudara" (Televisión Pública, 2013d, 00:04:22).
\end{abstract}

Feinmann, con su estilo más ornamentado, también rompe el acartonamiento de la clase al exclamar "escuchen bien esto que voy a decir», al entusiasmarse con un «es extraordinario» luego de citar a determinado autor o cuando inmediatamente después de hablar sobre Heidegger, su crítica a Sartre, su relación con el nazismo y su definición del lenguaje como la morada del Ser, se despide repentinamente con un «Bueno, hasta pronto» y se escabulle, como si se hubiera agotado de flotar en el vacío.

En ambos casos, además, la voz de los oradores se funde como una transición con la presencia de los personajes aludidos. Aparecen los dibujos de Lenin y de Mariano Moreno mientras Feinmann se va trasladando hacia un costado de la escena para cederles el lugar central. Como preámbulo de alguna de las intervenciones de Piglia escuchamos a Macedonio Fernández contar que iba caminando por la calle en noches pasadas cuando lo asaltaron, a pocos pasos de la comisaría, dos ideas de estética literaria, y esta alternancia tiene uno de sus puntos culminantes cuando el conferencista se refiere a Tlön y a la distorsión de la réplica mostrándoles a sus interlocutores la copia precaria de un caleidoscopio extraviado en su infancia y 
emulado para la ocasión por él mismo con ayuda de su equipo de producción. ${ }^{30}$ En las dos propuestas hay un juego donde lo real y lo ficcional desdibujan sus bordes.

El relato como espacio de disputa, por lo tanto, no se circunscribe al lenguaje político. Si retomamos otras intervenciones de los mismos autores que estamos analizando es inevitable acudir a las dos tesis sobre el cuento que propone Piglia ([1986] 2015) a propósito de una de las anécdotas registradas por Chéjov en su cuaderno de notas («Un hombre, en Montecarlo, va al Casino, gana un millón, vuelve a su casa, se suicida»). Escribió Piglia:

Primera tesis: Un cuento siempre cuenta dos historias. Un relato visible esconde un relato secreto, narrado de un modo elíptico y fragmentario. El efecto de sorpresa se produce cuando el final de la historia secreta aparece en la superficie. El cuento clásico (Poe, Quiroga) narra en primer plano la historia 1 (el relato del juego) y construye en secreto la historia 2 (el relato del suicidio). El arte del cuentista consiste en saber cifrar la historia 2 en los intersticios de la historia $1[\ldots]$.

Segunda tesis: la historia secreta es la clave de la forma del cuento y de sus variantes [...]. "El gran río de los dos corazones», uno de los relatos fundamentales de Hemingway, cifra hasta tal punto la historia 2 (los efectos de la guerra en Nick Adams) que el cuento parece la descripción trivial de una excursión de pesca. Hemingway pone toda su pericia en la narración hermética de la historia secreta. Usa con tal maestría el arte de la elipsis que logra que se note la ausencia del otro relato. ¿Qué hubiera hecho Hemingway con la anécdota de Chéjov? Narrar con detalles precisos la partida y el ambiente donde se desarrolla el juego y la técnica que usa el jugador para apostar y el tipo de bebida que toma. No decir nunca que ese hombre se va a suicidar, pero escribir el cuento como si el lector ya lo supiera (p. 105).

\footnotetext{
${ }^{30}$ La cita puede resultar extensa pero rememorar la escena merece la pena. Dice Piglia: «El objeto más maravilloso que hay en Tlön es lo que Borges llama hrönir. Yo había traído la cita pero me la dejé, no la quiero buscar ahora, y de paso ustedes leen el relato ¿no? Entonces dice: "cuando a uno se le pierde algo, el deseo genera el objeto, la réplica". Borges llama en el relato hrönir a un procedimiento por el cual uno materializa un objeto que ha perdido. Por supuesto, como es Borges, dice: "a veces la primera réplica es igual pero ya la segunda no... ya la segunda empieza a estar un poco distorsionada". Y a la gente le interesa la distorsión de lo que está buscando ¿no? A nosotros nos pasó eso... yo tenía este objeto que es una especie de caleidoscopio que me regaló un tío cuando yo era muy chico, en mi niñez, y que me ha acompañado. Un día lo perdí, lo perdí. Después apareció en un cajón pero... nosotros, mientras preparamos el programa, tratamos de construir... no construir, producir un Tlön. Producir un hrönir. Y entonces... esto fue lo que salió... esto ya, muy disminuido el pobre pero también con una pared de mi casa de la infancia. Entonces, ya ven que el hrönir tiene la virtud de que, si bien uno busca reproducir el objeto puro, el hrönir aprovecha para también poner algo que uno seguramente desea o recuerda con mucha nostalgia como yo recordaba la pared exterior de la casa. Entonces, acá tenemos un hrönir verdadero ¿no?» (Televisión Pública, 2013c, 00:21:30).
} 
Por su parte Feinmann (2016 b), en los capítulos de Filosofía aquí y ahora dedicados a la posmodernidad, reflexiona sobre la contraposición entre grandes y pequeños relatos. Según el filósofo un metarrelato establece un sentido, una linealidad, una utopía, un motivo de lucha, de praxis, un sujeto y un horizonte de plenitud. De acuerdo a este esquema, un gran relato asegura la plenitud del horizonte al que aspira. El capitalismo industrial es un gran relato. El marxismo es un gran relato, como el idealismo, la ilustración, las religiones y, desde ya, el populismo también lo es. ${ }^{31}$

En contraposición, la posmodernidad postula la muerte de los grandes relatos. La verdad no deriva de una cosmovisión articulada del mundo y, en cambio, es transmitida de manera fragmentada por los medios masivos. El receptor se aleja de la información recibida quitándole realidad y pertinencia, convirtiéndola en mero entretenimiento. Como se ha dicho, se cuestiona cualquier intento de totalización y se revaloriza el presente sobre el pasado y el futuro. Se puede afirmar algo con vehemencia y más tarde lo contrario. Cualquier espectador atento es capaz de ponerle nombres y apellidos a esta práctica.

Aquella disputa simbólica a la que nos hemos referido en este capítulo puede ser leída en esa clave. La denostación del relato populista funcionó como vedette del repertorio de despreocupado desprecio con el que ciertos personajes han recorrido los canales televisivos y las redes sociales para referirse a los gobiernos de Nestor Kirchner y, más aún, de Cristina Fernández. Podemos conjeturar que el empleo despectivo desde el cual se han apropiado del vocablo los sectores que pugnaban y pugnan- por el control y la circulación del discurso mediático pretendió naturalizar la cadena de significantes populismo-peronismo-kirchnerismo-relato-engaño, omitiendo la compleja polisemia que encierra este concepto y reduciéndolo a su resonancia mecánica, no con el objetivo de otorgarle un sentido sino de vaciar sus

\footnotetext{
31 Ver: Casullo, N. ; Forster, R. y Kaufman, A. (2009). Itinerarios de la modernidad: corrientes del pensamiento y tradiciones intelectuales desde la ilustración hasta la posmodernidad. Buenos Aires, Argentina: Eudeba, 2009.
} 
alcances para tornarlo fácilmente reproducible, estrategia anclada en la capacidad amplificadora de los grandes medios.

Las mismas fracciones apostaron en su táctica política a un muestreo de acciones no hilvanadas por ideas mayores que pudieran devenir autoritarias y eso fue ponderado como un valor, como una virtud. El acento se situó en la autenticidad y en la posibilidad de cambio a partir de la sumatoria de actos individualizados, simulando que éstos no se englobaban en instancias más abarcativas, lo que, por otra parte, es inverosímil: el macrismo posee también un relato, acaso el construido por los multimedios.

En este punto el camino elegido por buena parte del kirchnerismo al negar que su política pudiera ser entendida en ligazón a este concepto se vuelve, como mínimo, cuestionable ¿No es posible rescatar a los relatos como productores de sentido en el intento de construir una narrativa que, como señala Bajtín, ataña a una totalidad discursiva capaz de confrontar con los atomizados pero efectivos enunciados dominantes?

Hilos

En 2011, por decreto presidencial, se emplazaron dos retratos lumínicos de Eva Perón en las fachadas del Ministerio de Desarrollo Social. Las obras del escultor Alejandro Marmo, en colaboración con el artista plástico Daniel Santoro, fueron realizadas a escala monumental y en acero al cobre, un material que auto-bloquea la oxidación. De un lado, en una mirada firme y desafiante hacia el obelisco la Evita combativa del discurso previo a la renuncia a la candidatura por la vicepresidencia de la nación parece proyectar su voz quebrada sobre la 9 de julio. Del otro, con el corazón al sur como Eladia Blázquez, la flor en la solapa y el collar de perlas, la Evita solidaria de la tapa La razón de mi vida dirige su sonrisa amplia hacia Avellaneda. 

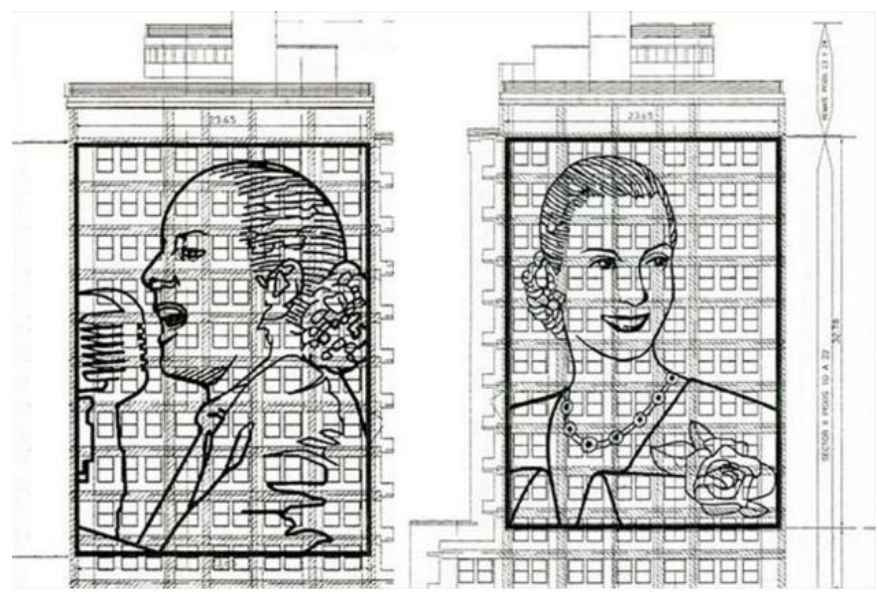

Dibujos de las esculturas de Eva Perón emplazadas en el Ministerio de Desarrollo Social

Tal vez, el hilo invisible que une en la dialéctica entre fuerza y vulnerabilidad a la construcción de liderazgos como el de Eva y como el de Cristina Fernández haya motivado la decisión de mantener estas esculturas en penumbras durante los cuatro años de ejercicio del gobierno macrista. $\mathrm{O}$ acaso las 14 toneladas de metal sean equiparables al peso específico que encarna la figura de Eva como emblema de una identidad nacional anclada en insignias que no siempre han sido estimadas como merecedoras de algún tipo de alumbramiento. Finalmente, como decía Marta Zátonyi en sus intransferibles clases de Estética, el arte participa siempre en la génesis de la verdad. 
CAPÍTULO $3 \quad \vdots$ SINOPSIS DE UN FESTEJO 
Qué patria celebrar y de qué modo materializar esa ponderación probablemente hayan sido preocupaciones nodales para la mesa chica que estuvo a cargo de organizar los festejos de la Revolución de Mayo. La Unidad Ejecutora Bicentenario de la Revolución de Mayo 1810-2010, creada a partir del Decreto Nacional $\mathrm{N}^{\circ} 1358$ de 2009, ${ }^{32}$ tuvo entre sus miembros a la por entonces presidenta de la República, Cristina Fernández de Kirchner, a su Secretario General, Oscar Parrilli, al Secretario de Cultura de la Nación, Jorge Coscia, al presidente del Sistema de Medios Públicos, Tristán Bauer, al historiador Felipe Pigna y al productor Javier Grosman, quien ofició de Director Ejecutivo de la gesta. Ese equipo proyectó un acontecimiento de impronta popular, federal y latinoamericana que delineó de antemano y a modo de premisa un acentuado contraste con los componentes que un siglo atrás habían caracterizado a los festejos centenarios.

Lo explicó la presidenta en una de las actividades centrales del martes 25 de mayo, cuando recibió a los siete presidentes de América latina que habían viajado para participar de la celebración y presenciar la inauguración de la «Galería de los Patriotas Latinoamericanos del Bicentenario». ${ }^{33}$ En su discurso, transmitido por cadena nacional, la mandataria aludió a cierta obsesión con la cual ella y su equipo trabajaron para concretar los festejos bicentenarios y para diferenciarlos de los de 1910, que habían sido obrados en medio del estado de sitio y la represión a las protestas sindicales, con la principal intención política de exhibir ante Europa los éxitos alcanzados por el modelo agroexportador:

Y por esas cosas de la naturaleza también o de las ideas, de querer siempre desde aquí parecernos a Europa y no ser nosotros mismos, americanos, latinoamericanos, habíamos traído como protagonista central de los festejos a un miembro de la Casa Real de España. Con todo el respeto que tenemos por todo, yo quería, en nombre de la historia de todos estos hombres y mujeres que están en esta Galería, y que en los últimos 200 años abonaron con su vida, con su sangre, con sus ideales, una América del Sur

\footnotetext{
32 Esa prescripción tuvo como antecedente el decreto presidencial emitido en 2005 por Néstor Kirchner para crear, en el ámbito de la Jefatura de Gabinete de Ministros, el «Comité Permanente del Bicentenario», a cargo de delinear un plan de acción para celebrar la efeméride, con el objetivo de otorgarle una relevancia primordial.

33 Una exposición permanente de retratos enviados por los distintos países a partir de una selección de figuras significativas para los entramados históricos nacionales y regionales.
} 
más democrática, con libertad pero para la igualdad; quería y queríamos darnos los argentinos un Bicentenario diferente; un Bicentenario popular, con el pueblo en las calles (Cristina Fernández, 2010). ${ }^{34}$

Así, este acontecimiento parece haber sido comprendido por sus hacedores como una oportunidad para volver sobre los principios de una identidad nacional en sintonía con definiciones específicas de lo popular y de lo latinoamericano. Recordemos que en esos años América Latina era gobernada por presidentes que, con matices, incluían en sus agendas la cuestión de la unidad continental y expresaban en acciones concretas, como el rechazo al Área de Libre Comercio de las Américas (ALCA) y la creación de la Unión de Naciones Suramericanas (UNASUR) y de la Comunidad de Estados Latinoamericanos y Caribeños (CELAC), la voluntad de enfrentar de manera mancomunada los obstáculos de la región.

Señalamos en la introducción que estos asuntos han sido analizados con hondura por investigaciones historiográficas, sociológicas y periodísticas con enfoques variados. Aquí tomaremos esos trabajos como referencia para centrarnos puntualmente en la propuesta estética y en las estrategias artísticas que se desplegaron durante la fiesta para revisitar aquella idea de nación fundante, vestirla con nuevas tramas, montar ese desplazamiento en el espacio público y convertirlo en un espectáculo masivo.

\section{Elogio de la multitud}

Los festejos tuvieron inicio el viernes 21 de mayo con el discurso de Cristina Fernández en lo que fue la inauguración del Paseo del Bicentenario, articulado sobre la Avenida 9 de Julio de la Ciudad de Buenos Aires. Ese espacio en la vía pública funcionó como escenario principal de las actividades más significativas durante los cinco días que duró la celebración. Allí se realizó también una feria donde cada provincia pudo exponer aspectos representativos de su historia, su geografía y su

34 Fernández, C. (2010). Palabras de la presidenta en apertura de Galería de los Patriotas Latinoamericanos. Recuperado de https://www.casarosada.gob.ar/informacion/archivo/22233blank-31757128 
cultura, un paseo gastronómico con puestos de comidas típicas y un conjunto de stands de los distintos ministerios de la Nación destinados a difundir los avances más significativos en torno a la educación, el medio ambiente, la cultura, la ciencia y la tecnología, la producción y los derechos humanos. Además, en sus distintos accesos se montaron tres pórticos intervenidos por diferentes artistas visuales. ${ }^{35}$ Se entraba a la historia a través del arte.

La agenda de la celebración mantuvo un tempo que podríamos llamar molto allegro, incluso a pesar de la reprogramación de algunas propuestas por la impiedad climática. Hubo a toda hora presentaciones de música, teatro y danza en los escenarios alternativos de las calles Belgrano, Alsina y Mitre, el partido amistoso de la Selección argentina -dirigida en ese momento nada menos que por Diego Armando Maradona - contra Canadá antes del Mundial de Fútbol fue transmitido por pantalla gigante, se inauguró la primera etapa del Centro Cultural del Bicentenario - hoy Centro Cultural Néstor Kirchner - en el ex Palacio de Correos y Comunicaciones y se realizó el tradicional Te Deum en la Basílica de Luján, con el acompañamiento de representantes de diferentes cultos y la lectura de un mensaje afectuoso enviado por el Papa Benedicto XVI.

A su vez, el Paseo fue marco de cinco desfiles: el militar, el federal, el Desfile de la integración, la exhibición Transportes de ayer y de hoy ${ }^{36}$ y el Desfile de los 200 años en el que, luego de la proyección sobre el Cabildo de un videomapping que sintetizó algunos momentos cruciales de la historia nacional, el grupo Fuerza Bruta

\footnotetext{
${ }^{35}$ La entrada de avenida Corrientes estuvo a cargo de Marcos López y del grupo GAC; la de Avenida de Mayo fue realizada por Graciela Sacco y León Ferrari; la puerta de Belgrano fue intervenida por el grupo Mondongo.

${ }^{36}$ El Desfile Militar congregó a fuerzas de seguridad y regimientos nacionales, ex combatientes de Malvinas, efectivos de distintos institutos militares y delegaciones extranjeras. En el Desfile Federal cada gobierno provincial diseñó un modo de intervención -hubo carrozas minuciosamente elaboradas, trajes gauchescos, alegorías a los diversos modos de producción nacionales y danzas y músicas características de todas las regiones del país-. El Desfile de la integración tuvo como principales protagonistas a las ochenta colectividades radicadas en el país a lo largo de la historia. En la exhibición Transportes de ayer y de hoy pudieron verse autos de industria nacional, colectivos antiguos, carros de bomberos históricos, taxis porteños y motos de época transitando la 9 de Julio.
} 
montó diecinueve cuadros destinados a realizar ese mismo ejercicio de condensación pero con el teatro experimental y la performance ${ }^{37}$ como principales recursos.

La 9 de Julio se transformó en una imagen urbana en movimiento (González, 2015). Esa marea de cuerpos, que lejos de mermar ganó volumen en el transcurso de las jornadas, fue pergeñando el material sustancial del Bicentenario pensado como una obra, cuya consigna compositiva parece haber sido la constancia de la intensidad.

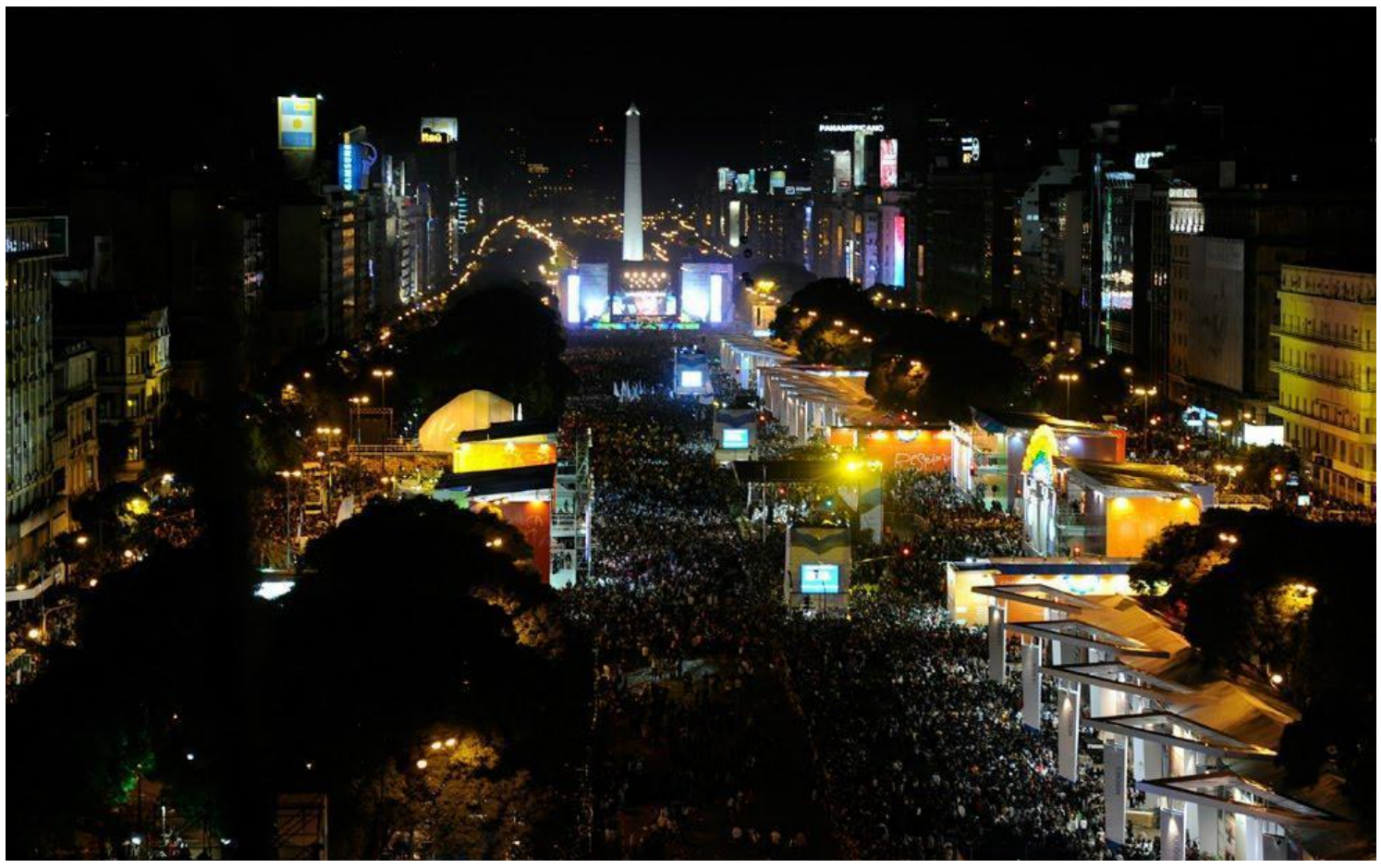

La Avenida 9 de Julio en una de las noches del festejo del Bicentenario. Imagen publicada por el Ministerio de Cultura de la Argentina

\footnotetext{
${ }^{37}$ Para comprender la complejidad de este término tan difuso como utilizado en la actualidad nos serviremos de las contribuciones de Diana Taylor (2012): «En Latinoamérica, donde el término no tiene equivalente ni en español ni en portugués, el/la performance tradicionalmente se ha usado en el campo de las artes, especialmente para referirse a arte de performance, arte vivo, arte-acción, accionismo. [...] las estrategias performáticas están profundamente enraizadas en las Américas, donde la transmisión del conocimiento y la memoria colectiva han cumplido un rol fundacional a lo largo de la historia. Los performances operan como actos en vivo o acciones corporales que transmiten saberes sociales, memoria y sentido de identidad a partir de acciones o comportamientos reiterados. [...] la palabra multidimensional apunta a las conexiones profundas entre los actos estéticos, políticos, económicos, lúdicos, sexuales, religiosos, etcétera» (pp. 35, 38, 47, 54).
} 
En palabras de Rodrigo Alonso (2000), toda intervención en el espacio público implica cierta alteración de los órdenes de circulación habituales, convierte a la ciudad en un escenario que dispone a los transeúntes como espectadores - tanto desprevenidos como voluntarios - e involucra una negociación entre identidades y representaciones públicas y privadas de las cuales la urbanidad es reservorio. Incluso cuando la obra se orienta a un único sector de este tejido complejo, su resultante se ve indefectiblemente conmovida por los modos en que esas transacciones se desarrollan.

En el caso que nos ocupa, la aspiración oficial de concebir un festejo diferente, con el pueblo en las calles, tuvo sin dudas su cauce en la concurrencia masiva y diversa que caracterizó a todas las actividades desplegadas a lo largo de la semana: grupos de jóvenes, una señora con su perro, cuarentones porteños, familias completas que viajaron desde el interior o que llegaron en subte desde el conurbano, murgueras, tangueros, rockeras, folcloristas, amantes del under, parejas con chicos, parejas de chicas.

¿Una explosión nacionalista en medio de la crisis de los relatos nacionales? Se preguntaba Pablo Alabarces (2010) en una nota de opinión publicada por Miradas al sur en los días posteriores al festejo. ¿O era, acaso, que no se había tratado de una crisis de la nación como forma sino de sus representaciones más ostensibles (la patria del "que se vayan todos», la desprestigiada escuela, el silenciamiento de la causa Malvinas después de la derrota, el peronismo devenido menemismo y hasta un Maradona fuera de foco)?. Alabarces diagnosticaba en aquél momento un retorno de la nación al centro de la escena, de la mano del Estado como principal operador:

No se trató de un proceso autónomo de la sociedad civil, a la que le sigue faltando, justamente, autonomía y fortaleza: la "gente» sale a la calle a partir de la convocatoria estatal, que propone de manera potente y creativa, la recreación del ritual escolar e infantil de la celebración de la patria. Sin himnos somnolientos ni discursos cansinos, sino con creatividad estética y pluralidad narrativa - difícil no sentirse contenido por todos o algunos de los fragmentos, tanto del desfile como del escenario artístico-. Y bien, el resultado es el éxito del ritual. Que no importa tanto como puesta en escena de lo que somos: el ritual es más interesante como celebración de lo que imaginamos (p.14). 
Probablemente ese pulso de un festejo de tinte más inaugural que anclado en la conmemoración tradicional sea una de las claves para interpretar la contundencia de la participación ciudadana, aunque no descartamos que esa disposición haya trascendido las expectativas del propio gobierno, que se fue de allí fortalecido, pero también con la tarea de interpretar esas voces para ofrecer una construcción formal capaz de contenerlas.

De un modo u otro, el tiempo real y cotidiano de la vida urbana fue suspendido en el tiempo de una obra protagonizada por multitudes que gestaron cierta materialidad bicentenaria en la que, además del componente heterogéneo por otra parte, tan propio de lo latinoamericano-, es posible identificar muchos de los rasgos que caracterizan a otras obras contemporáneas emplazadas en la vía pública: el uso de los cuerpos como elementos texturales, una escala definida por la yuxtaposición de partes, el empleo del entorno como soporte, la conjunción de aspectos previstos con elementos aleatorios, la búsqueda de sorpresa y de impacto y un carácter efímero que no va en detrimento de la profundidad. ${ }^{38}$

\section{Oíd el ruido}

«Lo que pasó fue tan fuerte que es inapelable» dijo Fito Páez sobre su experiencia en uno de los recitales más importantes de la semana. Cada día de celebración tuvo como cierre un espectáculo musical y para ello fueron convocadas figuras emblemáticas de la música popular de América Latina junto con solistas y grupos locales de reconocimiento más incipiente.

El Homenaje al rock nacional tuvo a Lito Nebbia como maestro de ceremonias para presentar a distintos artistas ${ }^{39}$ que interpretaron clásicos de Pescado Rabioso,

\footnotetext{
${ }^{38}$ Ver: Ciafardo, M; Belinche, D.; Maddoni, A.; Musso, M.; Sirai, A. y Delfino, L. (2019). La dimensión espacial de las imágenes visuales. En Ciafardo, M. (Coomp.), La enseñanza del lenguaje visual. Bases para la construcción de una propuesta alternativa (pp.147-201). La Plata, Argentina: Universidad Nacional de La Plata. Facultad de Bellas Artes.

39 Participaron Miguel Cantilo, Antonio Birabent, Emilio Del Guercio, Rodolfo García, Silvina Garré, Ricardo Soulé y León Gieco. El toque de gracia lo dio la aparición de Fito Páez para la interpretación
} 
Almendra, Aquelarre, Roque Narvaja, Moris y Los Gatos, sucedidos por los espectáculos de Árbol, Cuarteto de Nos, Estelares, Virus, Las Pelotas, Kapanga, Karamelo Santo, Los Pericos y Los Auténticos Decadentes. En el Homenaje a la música latinoamericana León Gieco recibió y compartió escenario con músicos locales y de distintos países del continente: Gilberto Gil (Brasil), Totó la Momposina (Colombia), Los Jaivas (Chile), Jaime Ross (Uruguay), Pablo Milanés (Cuba), Víctor Heredia y Gustavo Santaolalla (Argentina). También se celebró el Homenaje a la música folclórica, con la participación del Chaqueño Palavecino, Teresa Parodi, Bruno Arias, Liliana Herrero, Gustavo Santaolalla, Jaime Torres, y Soledad «La sole» Patorutti, encargada de anunciar a las 00 horas la llegada del 25 de mayo y de invitar a los millones que oficiaban de público a entonar el himno patrio, transmitido en vivo por cadena nacional desde el Valle de la Luna en San Juan.

Un comentario particular merece el Homenaje al cine argentino, en el cual la Orquesta Sinfónica Nacional ${ }^{40}$ interpretó las bandas de sonido de películas como Camila, El secreto de sus ojos, Juan Moreira y Diarios de motocicleta. Tengamos en cuenta que una orquesta sinfónica es una agrupación integrada por alrededor de ochenta instrumentos de viento, de cuerda y de percusión, que suele distinguirse por la ejecución de obras en las cuales los detalles de fraseo, la exactitud en las marcaciones a cargo del director o directora y la precisión interpretativa resultan fundamentales. La composición de piezas sinfónicas tiene en su génesis la posibilidad del trabajo con dinámicas - son habituales los pianos pianissimos y fortes fortísimos- y el horizonte de presentaciones en teatros preparados acústicamente, frente a un auditorio silencioso y quieto.

colectiva de uno de los himnos indiscutibles del género: «La balsa».

40 La agrupación fue creada en 1948, durante el gobierno de Juan Domingo Perón, como Orquesta Sinfónica del Estado, con el objetivo de que «constituya el diapasón de universal resonancia que nuestra música requiere y brinde, a la vez, el medio más eficaz de educación artística del pueblo (Decreto N³5879 del 20 de noviembre de 1948)». Ver: Orquesta Sinfónica Nacional (s/f). Acerca de nosotros. Recuperado de http://sinfonicanacional.com.ar/acerca-de/ 
Aquí, sin embargo, hablamos de un concierto montado en medio de la avenida más ancha de Latinoamérica, al aire libre, en un escenario con cualidades pensadas para espectáculos de otras características, con andamios, luces suspendidas, grandes pantallas y columnas de parlantes, frente a un hormiguero de pie y con una acústica absolutamente alterada por el bullicio.

Esta novedad en el emplazamiento implicó, sin lugar a dudas, decisiones formales para sopesar las modificaciones ineludibles en las condiciones de escucha. Por un lado, se alteraron algunos procedimientos compositivos que tienen que ver con el espacio en la música. Más allá de que el desempeño del sonidista resultó equiparable en importancia al del director, las intensidades fueron buscadas a partir de la simultaneidad y la singularidad más que desde el control de volumen en la ejecución de cada instrumento: se lograron dinámicas gracias a la alternancia entre pasajes tocados por un solista y la entrada de la orquesta. Por otro lado, hubo una cuidadosa elección del repertorio: obras más cortas y melodías ya conocidas por el público. El déficit acústico fue suplantado por la identificación, el recuerdo y el vínculo entre imagen visual e imagen sonora: mientras la orquesta tocaba, las pantallas gigantes reproducían fragmentos de los cortos y de los largometrajes aludidos.

De ese modo, en el Homenaje al cine argentino se produjo una reorientación del producto final en favor de generar un atajo hacia un tipo de música a priori concebida para su circulación en espacios históricamente ceñidos a las élites ilustradas. Y la formulación de ese atajo no se persiguió de manera mecánica en la acción de «sacar el arte clásico a la calle» sino que involucró ajustes y corrimientos en el seno mismo de las obras.

Un texto más ambicioso podría detenerse en cotejar este fenómeno multitudinario con lo que acontecía paralelamente en la reinauguración del Teatro Colón organizada por el gobierno de la Ciudad de Buenos Aires, que reunió a Mauricio Macri, Julio Cobos, Mario Das Neves y Hermes Binner, representantes de la por entonces oposición, con figuras del espectáculo como Mirtha Legrand, Susana Giménez y Ricardo Fort para presenciar una función de La Bohème de Puccini y 
admirar el esplendor recuperado. De un lado de las vallas, la civilización heredera de la patria centenaria, a salvo en la fastuosidad de un teatro cerrado, reservorio simbólico del gran arte. Del otro, la barbarie o lo que un indignado Pepe Eliaschev describió en esos días como "gente desorientada y condenada» (2010), ${ }^{41}$ en un texto de pretensiones literarias, aunque no tan bien escrito como "Casa Tomada», de Cortázar, o «La fiesta del monstruo», de Borges y Bioy Casares.

El cierre de la celebración de las hordas estuvo a cargo de Fito Páez que, además de interpretar buena parte de su amplio repertorio, cantó una versión del himno acompañado por una abultada columna de artistas y figuras de la cultura. ${ }^{42} \mathrm{La}$ imagen del rockero con su traje blanco frente a la avenida convertida en estadio supo resultar una de las postales del suceso.

Hablamos de un artista central de la escena musical argentina no solo por haber sido el responsable de récords de venta nacionales con álbumes como El amor después del amor (1992), por encabezar el desembarco de la trova rosarina en Buenos Aires junto a Juan Carlos Baglietto o por haberse transformado rápidamente en el niño mimado de figuras indiscutidas como Charly García o Luis Alberto Spinetta, sino también por el modo en que su obra logró sintetizar una poética devenida de su avidez literaria y de su cinefilia con el uso de un vocabulario urbano, coloquial y mordaz, tal vez acentuado por sus lecturas confesas de Osvaldo Lamborghini. El interés por historias marginales, pueblerinas y biográficas se combina en su discografía con un vuelco hacia los grandes dilemas existenciales - podemos registrarlas, por ejemplo, en uno de sus primeros hits, "Mariposa Tecknicolor», con pasajes como «Todo al fin se sucedió, solo que el tiempo no los esperó, la melancolía de morir en este mundo y de vivir sin una estúpida razón»- ${ }^{43}$ la identificación con un clima de época - en los desencantados fines de los noventa escribía: «Me gusta

41 Eliaschev, P. (2010). Patriotismo. Recuperado de https://www.perfil.com/noticias/columnistas/patriotismo-20100522-0042.phtml

42 Kevin Johansen, Juan Leyrado, Patricio Contreras, Diego Frenkel, Claudia Puyó, Rodolfo García, Fabiana Cantilo, Emilio del Güercio, Hugo Varela, Guillermo Fernández, Ariel Prat, Marcelo Moura, Juanse y el por entonces secretario Jorge Coscia, entre muchos otros.

43 «Mariposa Tecknicolor» es uno de los temas que integran el album Circo Beat (1994). 
estar al lado del camino, fumando el humo mientras todo pasa. Me gusta abrir los ojos y estar vivo, tener que vérmelas con la resaca. Entonces navegar se hace preciso, en barcos que se estrellen en la nada. Vivir atormentado de sentido, creo que esta sí es la parte más pesada»-, ${ }^{44}$ y el sondeo metafórico de pasiones transversales a cualquier hijo de vecino - ¿quién no encuentra algo de sí en las estrofas de «Un vestido y un amor»?: "Todo lo que diga está de más, las luces siempre encienden en el alma. Y cuando me pierdo en la ciudad, vos ya sabés comprender, es solo un rato, no más. Tendría que llorar o salir a matar. Te ví, te ví, te ví, yo no buscaba nadie y te ví»-. ${ }^{45}$

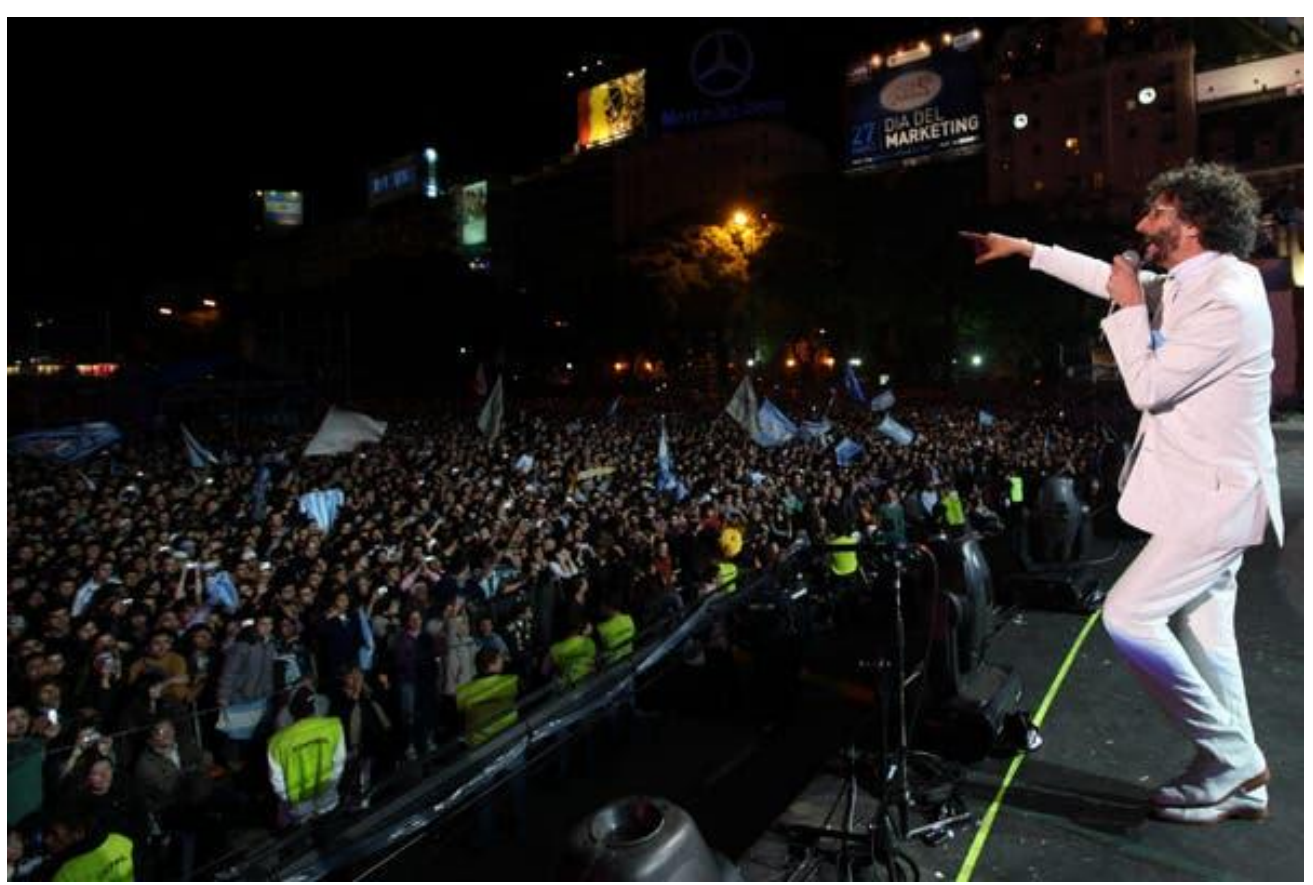

Fito Páez frente al público en el recital de cierre de los festejos bicentenarios. Fotografía de Soledad Aznarez

La voz rota y despreocupada, tan característica del cantautor, imprimió un rasgo de lo latinoamericano en un género universal, el rock, pensado por el capitalismo para ser exportado en todo el mundo. Esa misma ronquera que habilitó alguna vez a Fito a cantar "Los mareados» sin que tenga lugar un papelón mantuvo

\footnotetext{
${ }^{44}$ Se trata de «Al lado del camino», una de las piezas de Abre (1999).

${ }^{45}$ Fragmento de «Un vestido y un amor», canción incluida en el disco El amor después del amor (1992).
} 
al público eufórico hasta los últimos acordes que sonaron cerca de las dos de la madrugada.

\section{Diez minutos, treinta y tres segundos}

El videomapping es una técnica audiovisual que consiste en la proyección de imágenes visuales y sonoras sobre superficies diversas: muros, edificios, monumentos, etcétera. Como señalan Elisabeth Sánchez Pórfido y Lucía Gentile (2013) «El término proviene del verbo inglés "to map", que significa "mapear" o "cartografiar", y denomina a la técnica de proyección que requiere una previa caracterización topográfica de la superficie a la cual se adapta» (p.1). Se trata de una práctica cuya elaboración involucra un trabajo artístico interdisciplinario y para llevarla a cabo se utiliza un software que adecua la imagen a las características del área sobre la cual se proyectará, permitiendo tomar sus aberturas, sus relieves y sus desniveles como materiales de la obra.

Uno de los momentos cruciales de los festejos bicentenarios fue la proyección sobre el Cabildo de Buenos Aires de un videomapping que, en aproximadamente diez minutos y medio, propuso un relato audiovisual de la historia de la nación argentina. Esta pieza resultó significativa no solo por el impacto que tuvo su disrupción en el lugar para las y los espectadores allí presentes sino también por su transmisión televisiva y la circulación de esas imágenes en los días posteriores al acontecimiento.

En su exploración del vínculo entre celebraciones patrias y nuevas tecnologías a partir de los casos 2010 y 2016 en nuestro país, Milena Gutiérrez Celano (2019) define al videomapping como una reelaboración del imaginario urbano y detalla el modo en que la nueva ciudad imaginada genera sus efectos sobre la ciudad material:

Representa un pasaje de lo sólido a lo no sólido, de lo material a lo inmaterial, de la monumentomanía - donde se resalta el espíritu nacional por medio de operaciones urbanas y de implantación de monumentos y estatuas - hacia el espectáculo, el acontecimiento, donde los edificios se vuelven soportes de la imagen, de un mensaje que es socialmente compartido y de esta manera resignifica el espacio público [...] (p.3). 
Esa conversión transitoria del patrimonio memorial ${ }^{46}$ de la ciudad fue expandida a partir de su transmisión inmediata y de su reproducción en los medios de comunicación. Repasemos, entonces, de qué modo se planteó tal amplificación.

Tras unos segundos que mantuvieron al público en silencio y en penumbras, similares a los instantes previos al comienzo de un estreno en el cine cuando se apagan las luces y crece la expectativa, una música que podríamos catalogar como incidental, basada en la programación a partir de interfaces y bancos de instrumentos virtuales, dio pie a la aparición de fragmentos que comenzaron a iluminarse sobre la fachada de manera alternada hasta lograr la imagen completa del edificio en una versión cercana a la que conocemos en la actualidad: el Cabildo blanco, con su torre restaurada y su reloj impoluto. En menos de quince segundos el monumento histórico había perdido su estado sólido para dar paso a una nueva materialidad creada a partir de la luz.

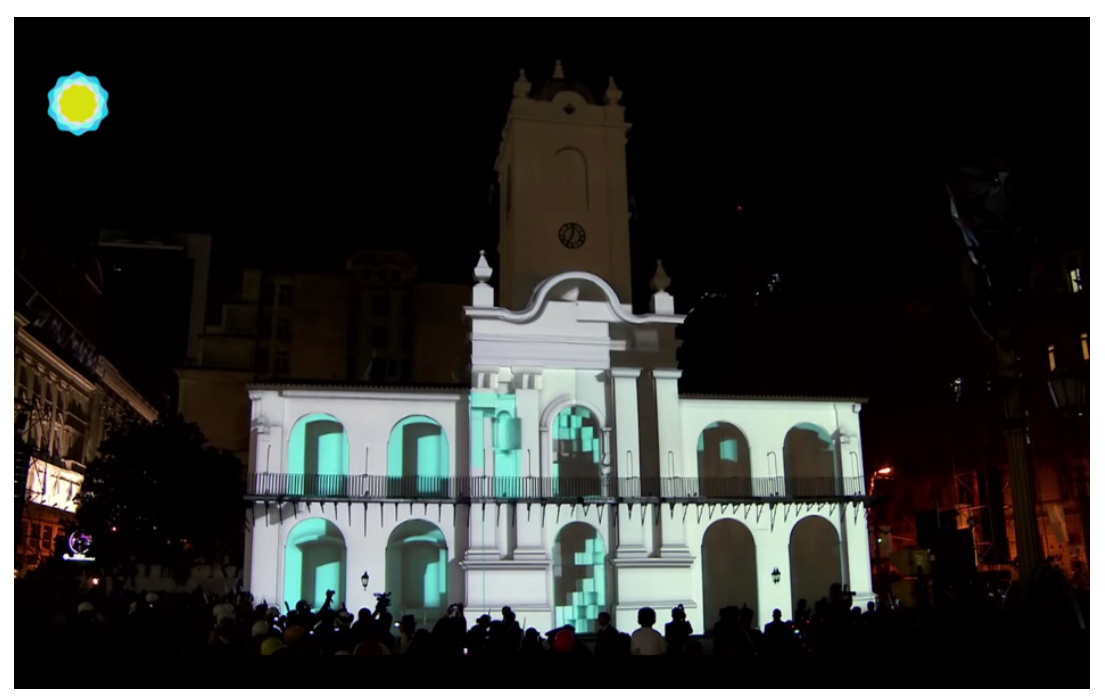

\footnotetext{
${ }^{46}$ Pierre Nora (2009) define como lugares de memoria a aquellos monumentos, espacios, paisajes, objetos, fiestas, emblemas, conmemoraciones, etcétera, que portan material o simbólicamente la memoria de una sociedad.
} 


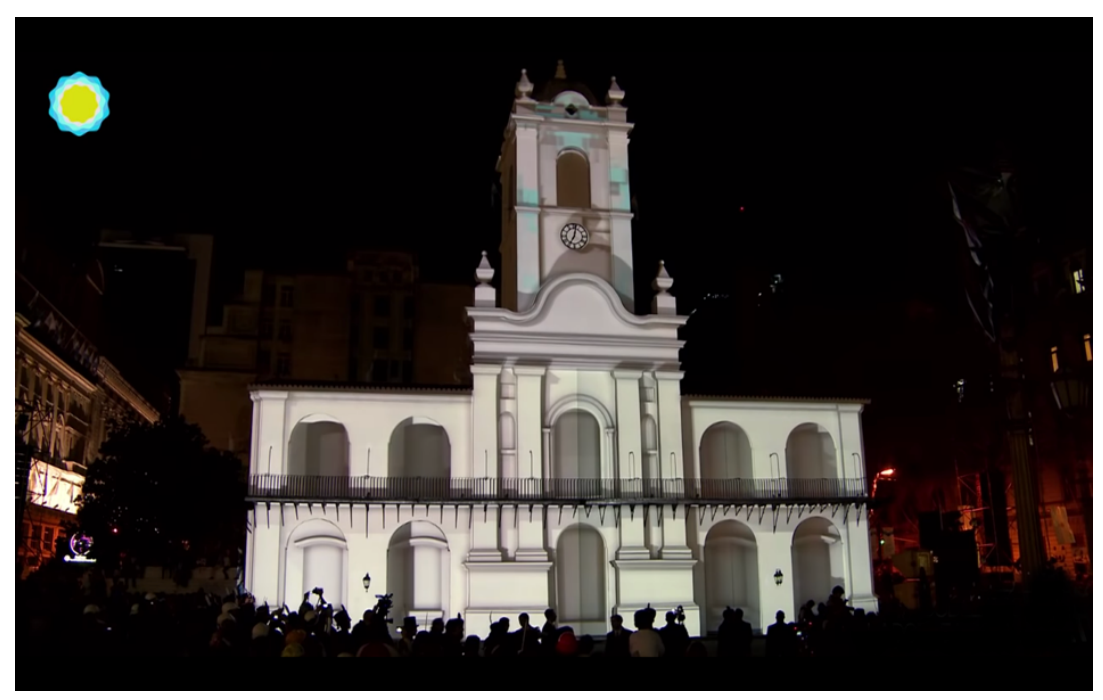

Momentos iniciales de la proyección sobre el Cabildo

Luego, la narración. Sobre un fondo sepia que permitía a los espectadores adivinar el retroceso en el tiempo se presentaron, en primer lugar, los enfrentamientos entre las milicias urbanas y las fuerzas inglesas en el Virreinato del Río de La Plata. Según argumenta Laura Amorebieta y Vera (2019), ese inicio dio cuenta de cierta ratificación, por parte de la Unidad Ejecutora, de la periodización clásica propuesta por la historiografía liberal, a partir de la cual se entiende a las invasiones inglesas como las responsables de esparcir la idea de libertad entre los porteños y de generar el impulso revolucionario. No obstante, esa validación de la historia oficial fue matizada luego en el mismo relato propuesto por el videomapping mediante la incorporación, dentro de las personalidades destacadas, de figuras intensamente cuestionadas por las tradiciones liberales — Juan Manuel De Rosas, por poner un caso-, la alusión a ciertos emblemas de la prédica nacionalista encumbrada por el revisionismo histórico, y el realce del pueblo como sujeto político transformador. En esta línea, Amorebieta y Vera sostiene:

los modos en que el gobierno de Fernández de Kirchner restauró el proceso de independencia dieron cuenta de un intento por reivindicar la gesta patriótica como criolla y popular, ideada y conducida por grandes hombres pero apoyada en las masas anónimas, lo cual no significó el abandono de aquella historiografía de corte liberal retóricamente cuestionada por la entonces mandataria ni una apelación total al arsenal del revisionismo histórico, sino más bien un cruce o conjugación de ellas (p.92). 
Esos esfuerzos conciliatorios de la mano de la apelación a la complejidad y del reconocimiento del conflicto como motor de avance explican de algún modo pasajes como aquél en el que los creadores se permitieron juntar en una misma escena los retratos enmarcados de Rosas, Sarmiento y Quiroga, en una seguidilla que enaltecía a los fundadores de la patria -San Martín, Belgrano, Saavedra, Moreno-, pero sobre un fondo alusivo a la pugna entre unitarios y federales.

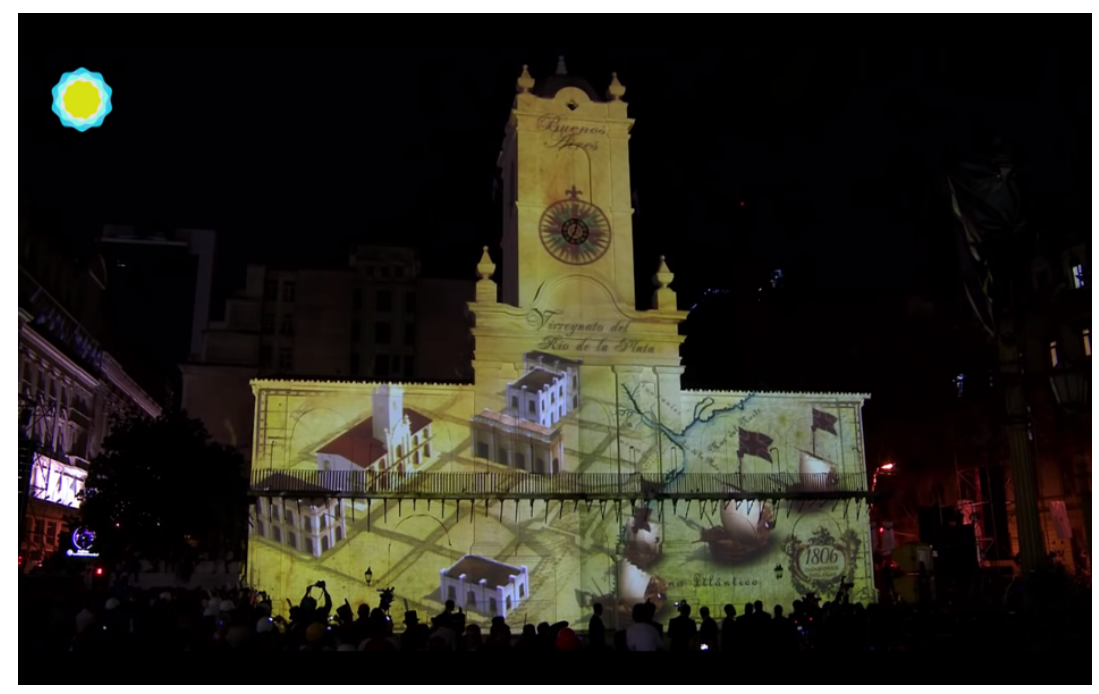

Escena de la resistencia contra las invasiones inglesas en el Virreinato del Río de La Plata

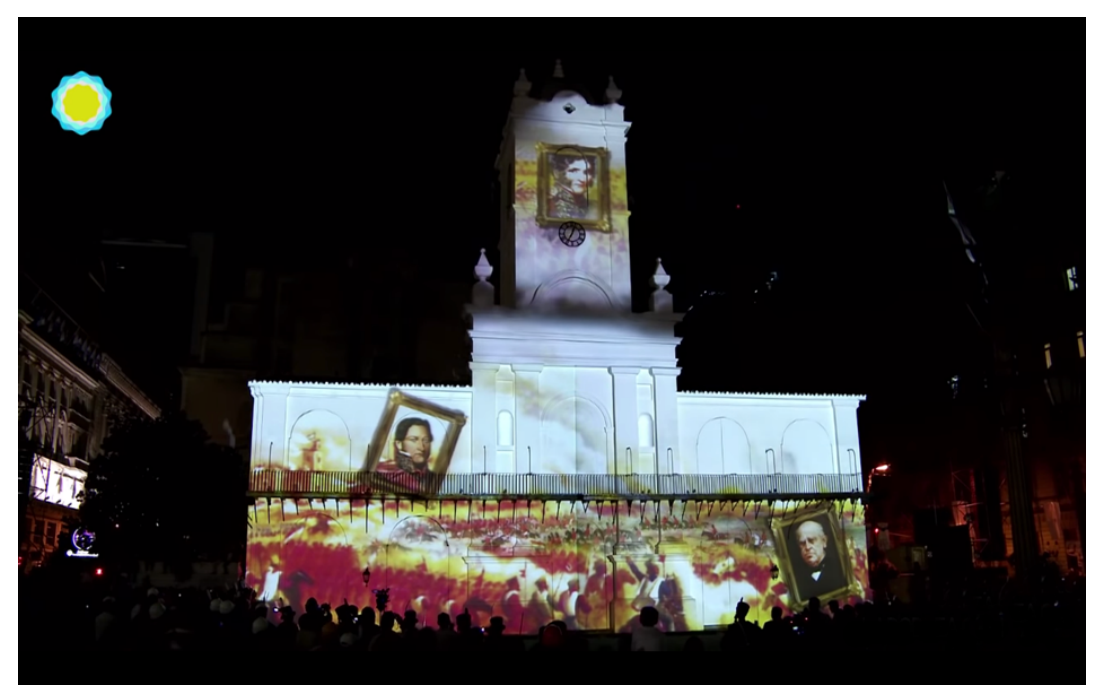

Retratos de Sarmiento, Rosas y Quiroga entre las figuras destacadas 
En el sumario del siglo XX se integraron algunos pasajes épicos, entre los que se encontró la referencia al período del primer peronismo, con un general sonriente saludando a las multitudes que marchaban mientras se oía la voz desgarradora de Eva dejando jirones de su vida por los descamisados, con otros segmentos de dramatismo logrado a partir del empleo del color y de variaciones rítmicas, melódicas y tímbricas, como las alegorías al terror estatal ejercido por la última dictadura cívico militar gracias al uso de un pleno rojo sangre que tiñó el cabildo completo al tiempo que sonaba un pedal repetido por un piano con ritmo lento y constante sobre un fade in de notas largas y en tensión ejecutadas por instrumentos de cuerdas, que se iba complejizando paulatinamente con la incorporación de percusión electrónica y células disparadas por sintetizadores.

La dificultad de atravesar la historia reciente, desde el retorno democrático hasta 2010, fue sorteada apelando a una sucesión de imágenes a gran velocidad y a la aparición de frases emblemáticas, capaces de condensar dos décadas: «Con la democracia se come con la democracia se educa con la democracia se cura»; ; «Quiero utilizar una frase que no me pertenece, porque pertenece ya a todo el pueblo argentino: señores jueces, nunca más»; ${ }^{48}$ "La casa está en orden y no hay sangre $;{ }^{49}$ "Basta de privaciones, ahora privatizaciones»; ${ }^{50}$ "Nada de lo que deba ser estatal permanecerá en manos del Estado». ${ }^{51}$

\footnotetext{
47 Frase pronunciada por Raúl Alfonsín en su discurso al jurar como primer presidente electo democráticamente después de ocho años de dictadura.

${ }^{48}$ Fragmento del alegato del fiscal Julio César Strassera en el juicio a los integrantes de las juntas militares, desarrollado en 1985.

${ }^{49}$ Durante la Semana Santa de 1987 un grupo de militares - «los carapintadas»- se sublevó contra el gobierno de Alfonsín para exigir la suspensión de los juicios a los militares comprometidos en delitos de lesa humanidad. Frente a esas presiones el presidente negoció lo que más tarde sería la ley de Obediencia Debida, que eximió a los militares por debajo del rango de coronel de la responsabilidad por los delitos cometidos bajo mandato castrense. Al anunciar el fin de la crisis ante una multitud, Alfonsín pronunció una de sus expresiones más recordadas: «jFelices Pascuas! La casa está en orden».

${ }^{50}$ Segmento de un spot publicitario de la década del 90.

51 Un furcio del por entonces ministro de Obras Públicas, Roberto Dromi, mientras leía los mandamientos del Decálogo menemista de la reforma del Estado, en compañía del presidente de la Nación.
} 


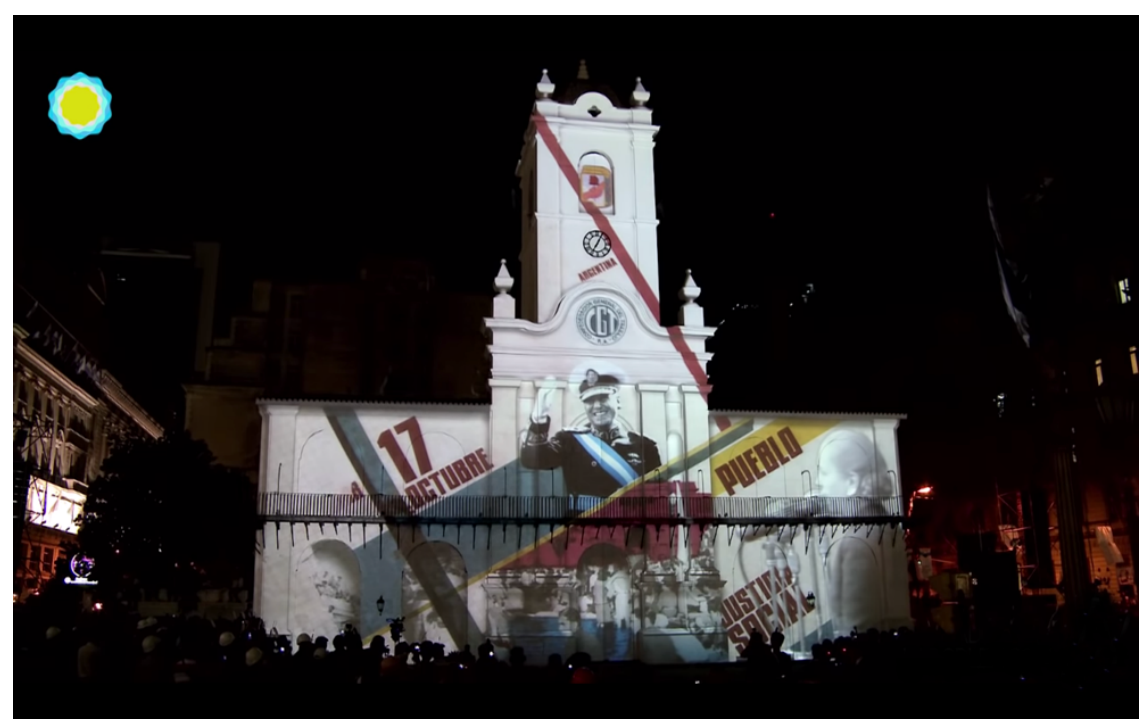

Pasaje vinculado a la etapa peronista

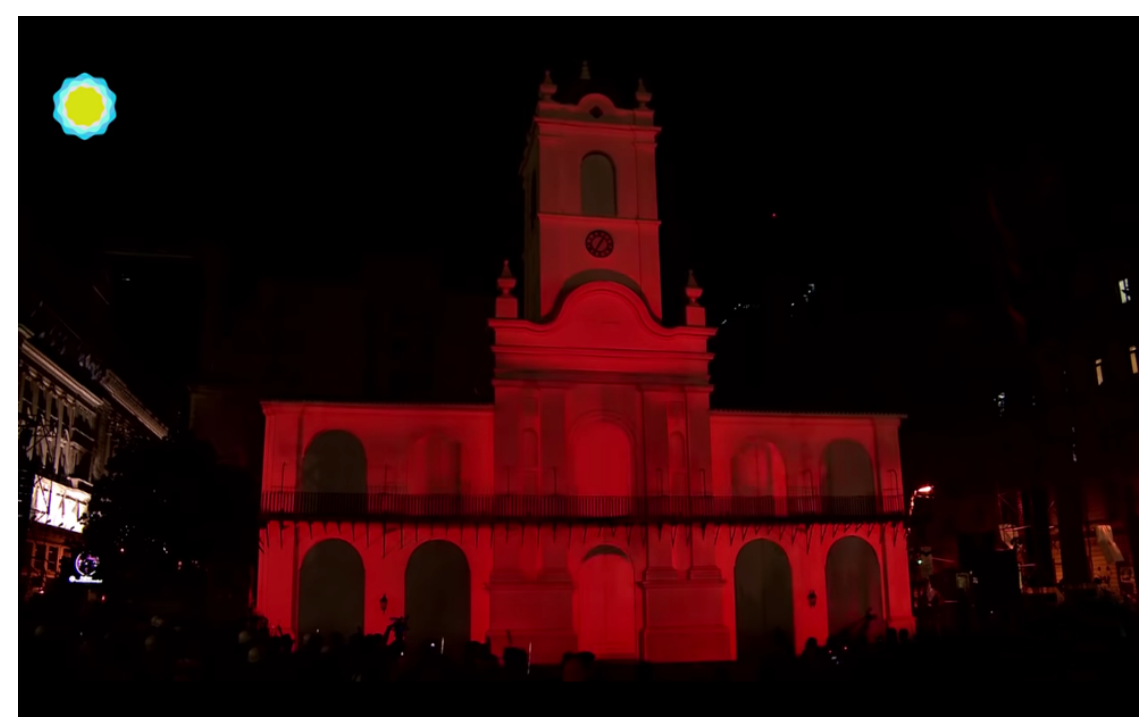

Fracción referida al terrorismo de Estado

Después de los registros de la crisis de 2001, el cambio de época y la etapa abierta en 2003 se marcó con la intercalación de imágenes de las Abuelas de Plaza de Mayo, de Hugo Chávez, Rafael Correa y Lula Da Silva, de estudiantes usando las computadoras del Plan Conectar Igualdad, de la anulación de las leyes de Obediencia debida y Punto final, de Cristina Fernández asumiendo la presidencia con el bastón de mando entregado por Néstor Kirchner, de trabajadores en las obras públicas y, por último, de un sinfín de personas anónimas en distintos cuadraditos, levantando 
hojas en las que estaba escrita su localidad de pertenencia, hasta cubrir la fachada completa del Cabildo, que luego pasó a ser celeste y blanca para después irse a negro y dejar únicamente iluminada una placa que rezaba «200 años. Bicentenario argentino", bajo el reloj cubierto por el sol amarillo, celeste y blanco que era el logo de los festejos.
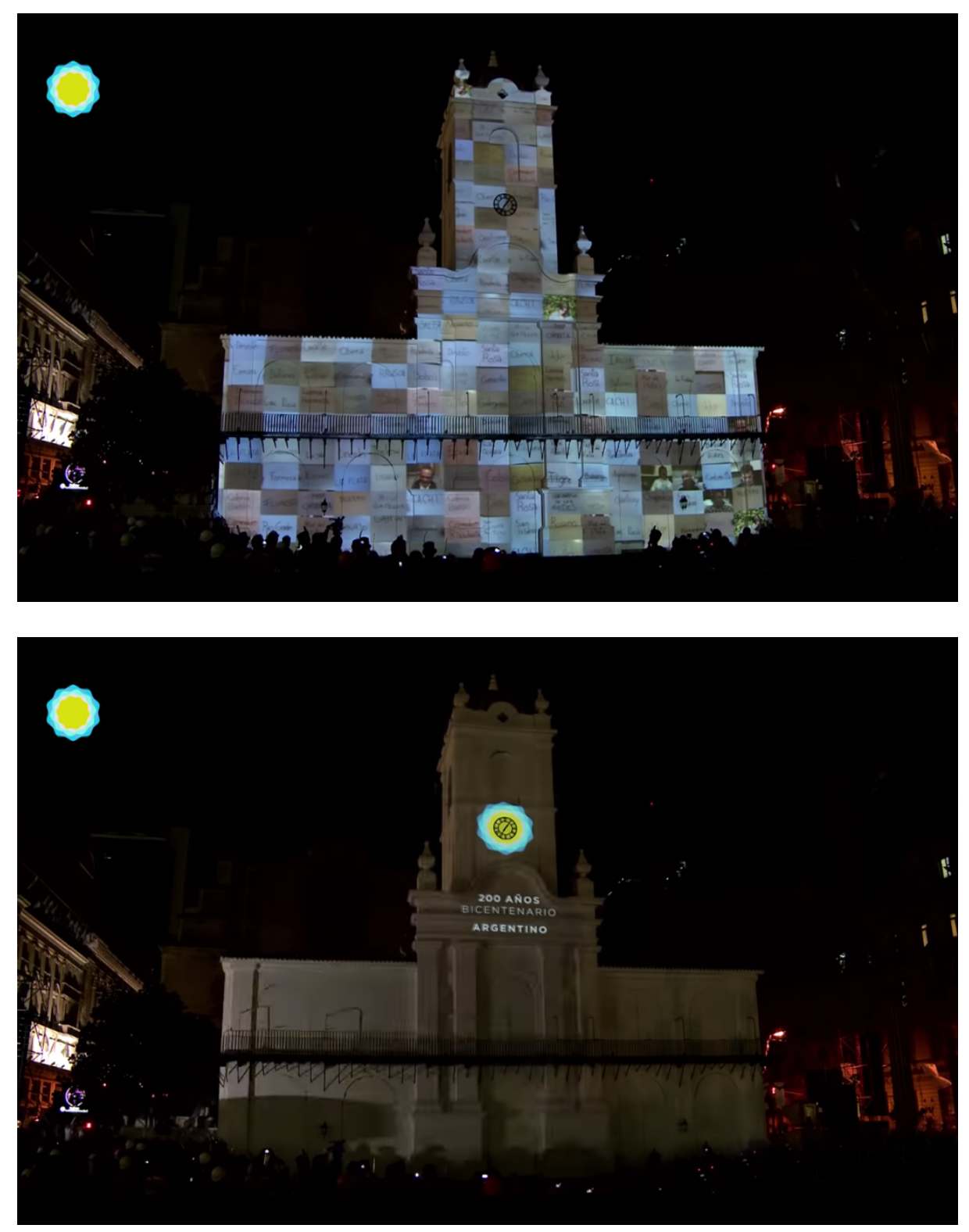

Las últimas dos escenas del videomapping 
Como infiere Pablo Ortemberg (2014) en su análisis comparativo sobre tecnología y espectáculo en diferentes conmemoraciones, el componente interdisciplinario que de por sí reviste el videomapping como manifestación multimedial contemporánea, en las fiestas patrias se complejiza con la intervención de funcionarios, asesoras y asesores de contenidos, historiadores, gestores culturales, etcétera. Para comprender ese trasfondo, nos interesa reponer el retrato que ofrece el autor:

El principal desafío, en realidad, fue conciliar la narración histórica con el principio efectista o "wow effect» intrínseco a la técnica. Parrilli quería resumir todo, algo imposible. Trímboli y Bauer estaban preocupados por la frivolización o estetización sin contenido y hasta errática en la que podían caer los «pibes de diseño y publicidad». Marqués cuenta como anécdota que en la parte donde aparece la Primera Junta, habían puesto aristócratas bailando, y que Bauer les marcó que no había sido una fiesta sino una revolución. Otro resquemor se presentó ante el predominio inicial de escenas belle époque para ilustrar el momento del Centenario. Trímboli se propuso tomar como eje las luchas populares, y se observa que el relato está teñido de un tono dramático puntuado con la serie de golpes militares alternados con momentos de felicidad, especialmente durante el primer peronismo. En la Quinta de Olivos se discutió sobre el lugar que ocuparía la figura de Yrigoyen y sobre la extensión e intensidad de la crítica a los gobiernos de Menem. Cristina, en la última reunión, pidió que Videla apareciera detrás de barrotes, algo que tuvieron que arreglar en el último minuto. Lo más delicado, comenta Marqués, fue trabajar desde el 2001 hasta el presente, porque estaba en juego la autoimagen del gobierno. «Fue todo muy paso a paso, con Bauer, [...] fue algidísimo", recuerda. Se resolvió un desenlace en el espíritu de la Patria Grande: incluir los rostros de Lula, Chávez y otros presidentes de la región (p. 174). ${ }^{52}$

Así, en un movimiento pendular entre voluntades políticas y estéticas y en la conciliación de tradiciones historiográficas de la que habla Amorebieta y Vera, finalmente la obra logró disponer un relato posible en lo que respecta al devenir de la nación y una presentación de la etapa kirchnerista como síntesis dialéctica de esa selección propia de individualidades, hitos y sujetos colectivos divergentes.

\footnotetext{
52 Javier Trímboli es el historiador que trabajó como asesor de los contenidos del videomapping y Joaquín Marqués integraba la productora La Doble A, que en 2010 sub contrató a Shango Films para realizar la animación y el vfx (visual effects) de esa obra.
} 
Con todo, el compás vertiginoso del encadenamiento audiovisual, la ausencia de una voz en off que condujera la interpretación de lo visible, el pasaje de una etapa a la otra mediante saltos temporales, la fusión de unas imágenes en las siguientes y la superposición de escenas con el uso de las ventanas del Cabildo como pequeños televisores que proyectaban de manera simultánea situaciones diferentes -como ocurre en la historia pero no siempre en su figuración- dejaban en manos de los espectadores una tarea compleja cuya resolución escapó de antemano a cualquier posibilidad de previsión por parte de las y los autores.

\section{Alta en el cielo}

En el centro de la Diagonal Norte una mujer de pelo negro y tez oscura corre en el aire. Sus brazos se mueven en un gesto similar al de los pájaros, pero las piernas la delatan: ella corre. El vestido blanco, de género ligero, se deja tornear por el viento dibujando ondulaciones asimétricas. Sobre los hombros lleva una capa celeste también etérea con la que juega: la toma y la suelta, traza ochos en el aire como lo haría una malabarista del fuego. Sujetada únicamente por el cable tensor que cuelga del brazo de una grúa, la mujer alterna el aleteo con los saludos que dirige a un público exultante. La grúa avanza lentamente, escoltada por un grupo de músicos que interpretan ritmos del altiplano con quenas, sikus, bombos legüeros y cajas chayeras.

La mujer es Argentina, con mayúscula, y hablamos de uno de los diecinueve cuadros que compusieron el Desfile del Bicentenario, el cual recorrió en el lapso de dos horas el tramo que separa Plaza de Mayo de la Avenida Independencia y cuyas imágenes más emblemáticas se encuentran a nuestro alcance gracias a ese archivo tan segmentado como extenso que es YouTube. 


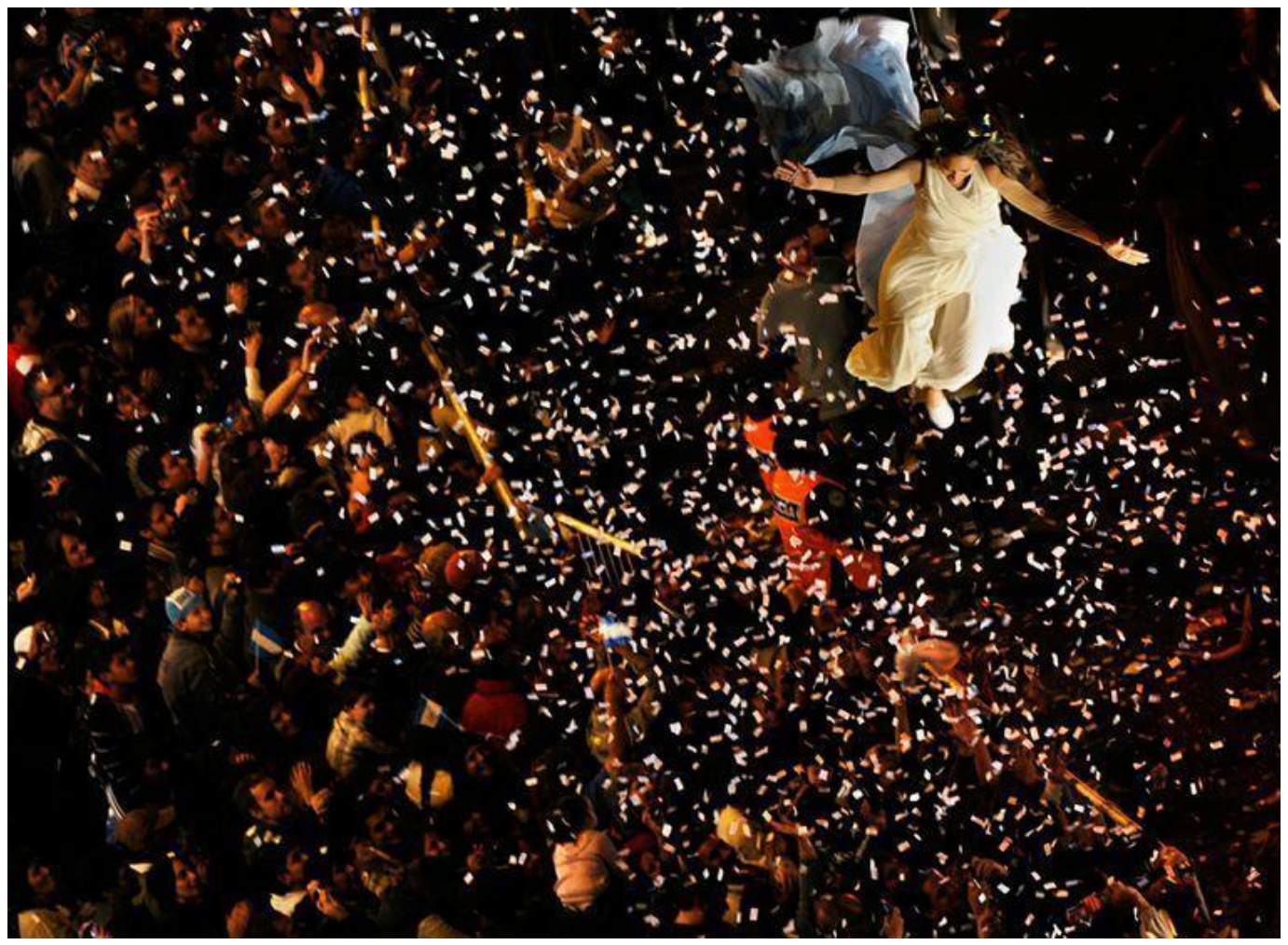

Cuadro inaugural del Desfile del Bicentenario. Fotografía de Daniel García, agencia AFP

Para la producción artística de ese acontecimiento sin precedentes en la vía pública, la Unidad Ejecutora del Bicentenario decidió convocar a Diqui James, Fabio D’Aquila y Gaby Kerpel, directores del proyecto de arte performático Fuerza Bruta y artífices del espectáculo homónimo cuya carta de presentación rezaba: «No existe en la obra el concepto de significado o representación. Una puerta es una puerta. No significa ni más ni menos que eso. Tampoco el vestuario, las luces, la música ni los gestos. La luz roja es una luz roja o lo que usted quiera» (James, s/f)..${ }^{53}$ La elección de Fuerza Bruta fue tan arriesgada como probable, si tenemos en cuenta que el grupo organizador de los festejos contaba entre sus miembros a dos cineastas, al fundador del Centro Cultural Babilonia - templo del arte alternativo montado en un ex depósito de bananas en pleno Abasto- y a unos cuantos entusiastas de la espectacularidad.

53 James, D. (s/f). Fuerza Bruta. Disponible en: http://www.alternativateatral.com/obra4766-fuerzabruta. 
El armado implicó el trabajo fino de escenógrafas, diseñadores, vestuaristas, iluminadoras, maquilladores y diversos colectivos artísticos. Algunos cuadros fueron realizados con la participación de músicos que tocaron en vivo y otros tantos utilizaron composiciones grabadas. Los ensayos se realizaban a las tres de la mañana, cuando la calle estaba vacía. Para habilitar el paso de las carrozas se talaron más de 70 árboles, se eliminaron unos cuantos canteros y se modificaron las veredas. La organización implicó reuniones con el Correo Argentino, la Policía Federal, el Instituto Nacional del Teatro, los Bomberos y el INCAA. En la escena "Los Inmigrantes» se utilizó un barco de casi 40 metros de largo para representar la llegada de las distintas comunidades: «[...] arriba los que llegaron por mar (italianos, españoles, etcétera). Abajo, los que llegaron por aire y tierra: la comunidad andina y los taiwaneses en representación de las olas inmigratorias del siglo XX» (Siddig, 2010, p. 19).

El montaje de los cuadros contó con la participación de dos mil artistas cuyas actuaciones simultáneas avanzaban una tras otra en dirección a la 9 de Julio. Junto con «La Argentina», que encabezaba la procesión, el desfile desplegó otras dieciocho escenas móviles: «Los Pueblos Originarios», «El éxodo jujeño», «El cruce de los Andes», "La Vuelta de Obligado», "El folklore (los frutos de la tierra)», "Los inmigrantes», «El tango», "Movimientos políticos y sociales», "La industria nacional», "Democracia y golpes de Estado», "Derechos Humanos», "Madres de Plaza de Mayo», "Malvinas», "El Festejo del regreso a la democracia», "Crisis económica», "Latinoamérica», "El presente y el futuro» y «El rock nacional». Las diecinueve estampas finales fueron elegidas de una lista bastante más extensa y en esa depuración participaron los integrantes de Fuerza Bruta, los organizadores del Bicentenario - con Felipe Pigna como historiador asesor- y, centralmente, la presidenta. Tal como dejan entrever los títulos, en esa selección temática parece haber primado un sentido historiográfico cercano al análisis los tiempos de media y larga duración enunciados por Fernand Braudel (1979), más que el intento de contarlo todo o la búsqueda de un relato acontecimental.

Desde la primera reunión Diqui James planteó la necesidad de crear un espectáculo móvil, que pudiera ser visto desde distintos puntos por mucha gente y 
que tomara como elemento principal las carrozas propias de las festividades carnavaleras. Sabemos de las polémicas historiográficas respecto del origen europeo del carnaval ${ }^{54}$ y de los empeños teóricos para rastrear su introducción en las colonias americanas a partir del siglo XVI, sus reelaboraciones y apropiaciones en todo el continente y los posteriores intentos de control y prohibición de estas fiestas por parte de las cúpulas eclesiásticas, civiles y políticas de la estructura colonial. Conocemos también que este marco represivo tuvo su reedición en la Argentina del siglo XX cuando en el contexto de la dictadura militar iniciada en marzo de 1976 se eliminaron los feriados destinados a realizar tales festejos y que, probablemente, ese sea uno de los motivos por los cuales a nuestros carnavales ${ }^{55}$ no hayan alcanzado aún las mismas dimensiones que los de otros países latinoamericanos, como el Carnaval de Oruro en Bolivia y el de Barranquilla en Colombia, que han sido reconocidos por la Unesco como patrimonios inmateriales de la humanidad (Flores Martos, 2001; Mariano \& Endere, 2017). Sin embargo, desde principios de los 2000 diversos colectivos en el país comenzaron a activar la puesta en valor de estos festejos populares y buscaron marcos legales para respaldar su legitimidad: normativas tendientes a promover ensayos y actuaciones en predios municipales, a motivar la organización de corsos en los barrios y a propiciar el desarrollo de la comunidad del carnaval. ${ }^{56}$

\footnotetext{
${ }^{54}$ Hay quienes remontan sus antecedentes a las fiestas paganas de los griegos y los romanos y lo vinculan con la adoración de Isis, la Diosa de la maternidad y de la fertilidad. Sus detractores aseveran que el Carnaval es hijo legítimo del cristianismo y que ha sido introducido en Europa durante la Edad Media.

${ }^{55}$ De todas formas, es importante destacar las diferencias sustanciales entre el desarrollo de estas festividades en provincias como Corrientes, Entre Ríos, Córdoba, La Rioja, Salta o Jujuy y el que remite a los carnavales porteños.

${ }^{56}$ En 2010, apenas unos meses después del Bicentenario, fueron restituidas las fechas del lunes y martes de carnaval como feriados nacionales mediante el Decreto 1584 que consideraba al carnaval como «una de las manifestaciones más genuinas de las diferentes culturas que habitan nuestro vasto territorio, que fomenta la participación y la transmisión de los valores que nos identifican [...]». Ver: Decreto 1584/2010 (2010). Decreto de Feriados Nacionales y días no laborables. Boletín Oficial de la República Argentina. Recuperado de
}

http://www.mininterior.gov.ar/asuntos_politicos_y_alectorales/dinap/feriados/1584.pdf. 
En este sentido, la propuesta de James, tal vez sin proponérselo, dialogó con una tradición latente en la cultura popular argentina y habilitó la resignificación de un formato cercano para la mayor parte de los espectadores, que porta en su génesis el carácter festivo, la comunión, el disfrute al alcance de todas y todos como forma de resistencia a los valores y las jerarquías impuestas. Esa cultura popular de la risa, en palabras de Bajtin ([1933] 2005), produce una experiencia:

Los espectadores no asisten al carnaval, sino que lo viven, ya que el carnaval está hecho para todo el pueblo. Durante el carnaval no hay otra vida que la del carnaval. Es imposible escapar, porque el carnaval no tiene frontera espacial. En el curso de la fiesta sólo puede vivirse de acuerdo a sus leyes, es decir de acuerdo a las leyes de la libertad (p.3).

Se trata de un ritual capaz de suprimir de manera transitoria las diferencias y de entrecruzar los cuerpos en un tipo de vínculo sensorial que disuelve los límites entre el juego y la realidad, entre lo sagrado y lo profano, entre lo culto y lo común a partir de una vitalidad grotesca y desterritorializada.

Tradición y contemporaneidad. La idea de estar en ninguna parte es una idea contemporánea. Muchas de las representaciones del desfile se desplegaron en un espacio físico difuso. El fondo estaba borrado, como sucede en el arte contemporáneo universal, tangible en internet y en una obra de Liliana Porter en la que una mujer ve el oro en la nada. 


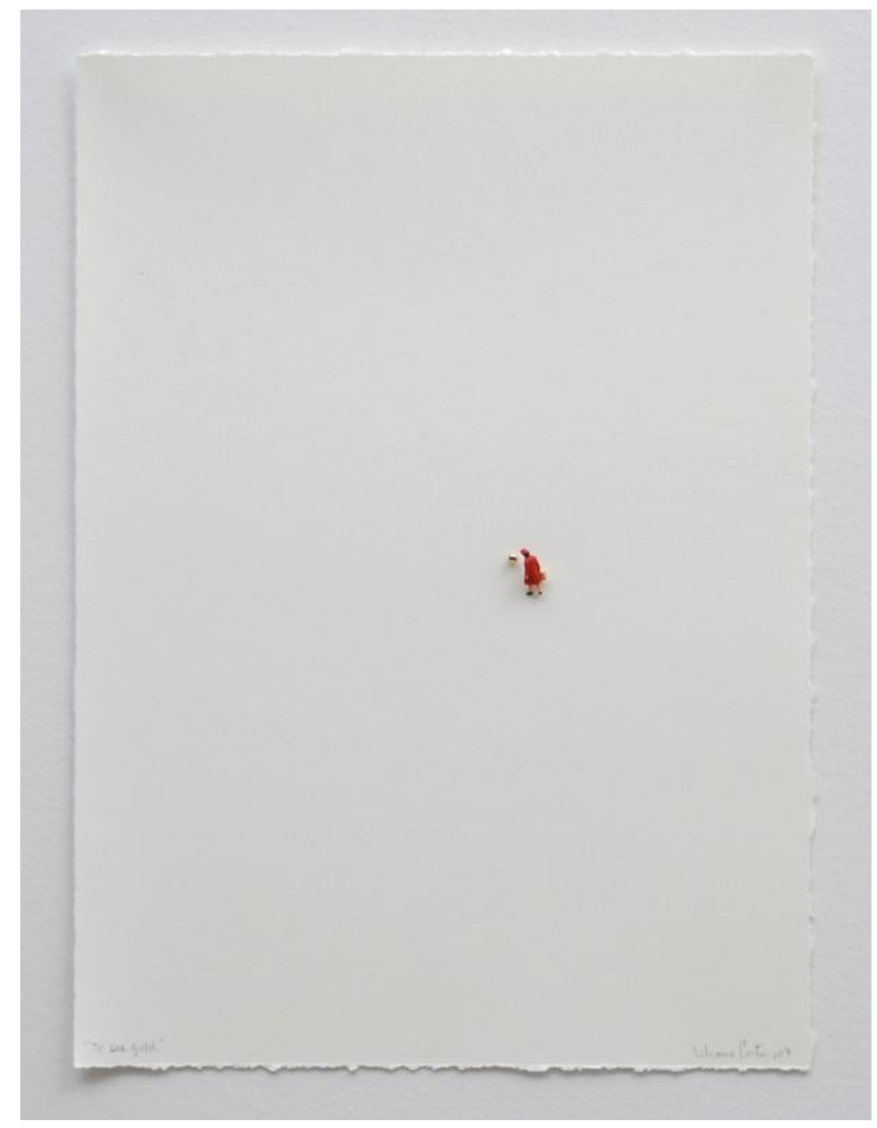

Liliana Porter (2007). To see gold

En la entrevista que se realizó en el marco de un ciclo de conversatorios organizado por la Secretaría de Arte y Cultura de la UNLP en 2015, Porter fue consultada por Mariel Ciafardo con respecto a la presencia del vacío en su producción. En esa oportunidad la artista comentó:

Lo que me interesa, justamente, es no ponerle una temporalidad. Al no estar en ningún lado, supongamos que sea una foto de un personaje, no está arriba de la mesa, no está en este año, no está en el pasado, está ahí. Y, de ese modo, pareciera que va más directo, como si se viera más. El contexto explica demasiado, pero si no tiene contexto se vuelve más esencial y esa es una cualidad que creo que mis obras, desde fines de los sesenta, siguen teniendo. Incluso, en la obra de teatro el fondo es negro, monocromo, no hay casi escenografía (p.33)

Buena parte de los cuadros del desfile que aquí nos concierne se configuraron en esa suerte de fractura espacial y temporal de la que habla Porter, aún cuando se 
tratara de escenas que de un modo u otro buscaban encarnar un tramo del acontecer nacional. En esos surcos desde los cuales el arte desafía a la física permitiendo que una manzana se sostenga en el aire sin caer, allí donde un elemento tan insignificante ${ }^{57}$ como un pequeño hilito logra ser potenciado en su propia condición a partir de las elecciones de escala y emplazamiento, la ausencia de sonido puede alzarse como material suficiente para condensar una fisura en la historia.

Si quienes leen estas líneas interrogan a sus parientes acerca de lo que recuerdan de aquellos días de fiesta callejera probablemente más de una respuesta hará alusión a «la carroza de las Madres», o al menos así ocurrió en nuestra encuesta casera. Para esa estampa, Fuerza Bruta utilizó tres materiales sencillos: el agua, el silencio y la luz. Arriba de una estructura metálica absolutamente despojada que se alzaba del suelo con la noche como fondo, alrededor de veinticinco mujeres vestidas con pilotos neutros y oscuros caminaban en ronda a paso lento. Una detrás de la otra. En sus cabezas brillaban los pañuelos blancos, iluminados mediante luces led imperceptibles. Sobre la pasarela por la cual se desplazaban los cuerpos caía una Iluvia fina pero constante. En algún momento el movimiento circular se detenía. Las mujeres permanecían en franca quietud, bajo la lluvia, mirando a las y los espectadores a los ojos. El silencio de esa escena, en medio del alboroto general en la Avenida, resultaba ensordecedor. Después de unos segundos, percibidos probablemente como minutos largos, la marcha reanudaba para volver a detenerse luego frente a otro tramo de multitud.

El cuarto elemento compositivo utilizado para ese cuadro fue el giro. La performance dentro de la performance. ${ }^{58}$ Se tomó como material el movimiento

\footnotetext{
57 En otra entrevista, al ser interrogada acerca del empleo de los materiales en sus obras, Porter explicaba: «El arte boludo (así lo llamábamos Luis y yo) consiste en lo siguiente: elegir cosas que no signifiquen nada (lo cual sabemos que es imposible), optar por los elementos menos misteriosos del mundo (aunque de hecho terminen siendo misteriosos). Buscar lo más neutro, lo menos expresivo: un ganchito, una sombra, un hilito...» (Fundación Cisneros, 2013, p.147).

58 Dice Taylor (2012): «Las Madres de Plaza de Mayo han usado un pañuelo blanco y procesado siempre un mismo día y a una misma hora durante más de cuarenta años. Fue una lucha por el espacio y por hacer visibles los crímenes de la dictadura. Han dejado una marca definitiva. Su performance político ha sido duradera» (p.20).
} 
desvelado de esas mujeres que alguna vez decidieron salir de sus casas a enfrentar al aparato represivo, caminando en sentido contrario a las agujas del reloj para vencer al tiempo. La escena fue completada en cada trecho por las reacciones de la gente en un abanico que incluyó aplausos, miradas conmovidas a las protagonistas reales de esas rondas que también se encontraban en la calle celebrando y ecos del siempre bien dispuesto canto popular: «madres de la plaza, el pueblo las abraza».

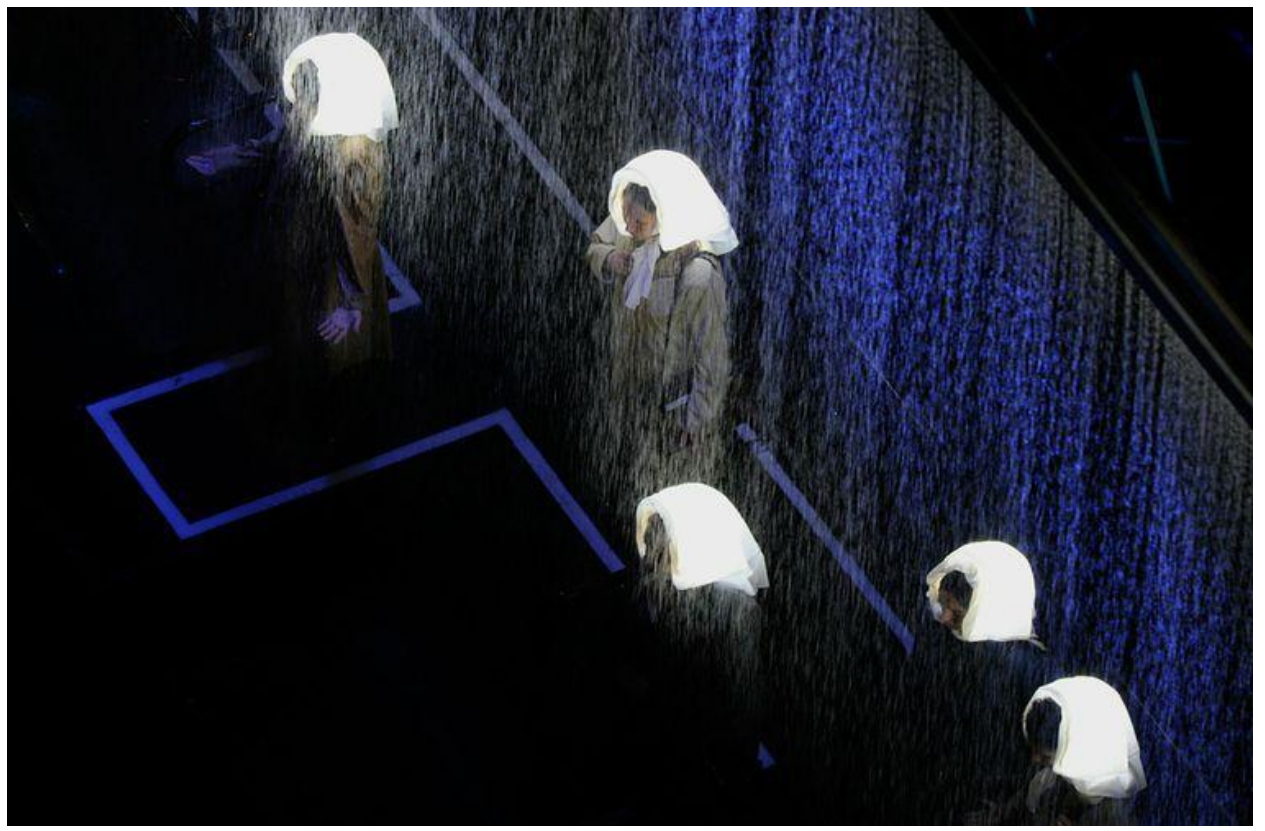

Escena móvil titulada «Madres de Plaza de Mayo». Fotografía de Daniel García, agencia AFP

Los diecinueve cuadros dispusieron una ruptura espacial en varios planos, distanciándose del modelo teatral a la italiana, donde lo que acontece tiene lugar frente al público. La acróbata que representó a «La Argentina» corría sobre el aire. Sin embargo, a partir de una de las categorías compositivas del arte, el desplazamiento, ese no lugar fue sustituido por una herramienta simbólica de fuerte pregnancia histórica y material: la bandera. El lugar, allí, fue la bandera, la historia. 


\section{Lejanía}

La inauguración de la Galería de los Patriotas Latinoamericanos, la participación de artistas reconocidos de distintos países del continente en los recitales nocturnos, el Desfile de la Integración, una carroza destinada a los pueblos originarios y otra alusiva a la migración de los países limítrofes en el espectáculo de Fuerza Bruta y la presencia de los presidentes de Uruguay, Paraguay, Brasil, Bolivia, Ecuador, Chile y Venezuela podrían bastar como evidencia para sostener que la organización de los festejos del bicentenario de la Revolución de Mayo fue trazada en sintonía con una idea de nación intrínsecamente ligada a los componentes que definen la identidad de América Latina.

De cualquier modo, no hemos ahondado aquí en el contenido del relato kirchnerista sobre la historia nacional, sino en su forma. En ese plano despuntó, tal vez, algún entendimiento de lo identitario que más que anclar en definiciones dogmáticas y cristalizadas respecto de lo nacional y de lo latinoamericano apeló a la apropiación colectiva de un imaginario situado.

En esta celebración se complementaron sin complejos categorías que suelen aparecer enfrentadas en el campo teórico. De un lado, la originalidad, la búsqueda de rupturas formales y el empleo de operaciones retóricas; del otro, lo masivo, lo reconocible, lo popular. Esos rasgos que en la crítica estética se enuncian contradictorios convivieron y habilitaron una redefinición de lo aurático en el sentido de algo que se percibe como si ocurriera por primera vez pero que, al mismo tiempo, resulta familiar. La posibilidad de ver una cosa en otra, tan propia del arte, permitió refutar una idea muy instalada respecto de la supuesta incapacidad de lo popular para adentrarse en la hondura del efecto de extrañamiento. Como diría Benjamin: en lo cercano, una lejanía. ${ }^{59}$

\footnotetext{
${ }^{59}$ Sin introducirnos en las controversias que ha desatado la categoría benjaminiana de aura en las teorías estéticas contemporáneas nos interesa rescatar la idea de que en la obra de arte ocurre cierta «manifestación irrepetible de una lejanía (por cercana que pueda estar)» (Benjamin, 1989, p.24) y que allí se instituye una condición específica de la experiencia y un trabajo de la memoria capaz de conjugar distintas temporalidades en un mismo objeto, como sostiene Didi Huberman (2006) en su observación sobre el carácter difuso de la idea de aura en toda la obra de Benjamin.
} 


\section{CAPÍTULO $4 \quad \vdots$ MEMORIA Y ASOMBRO}

distintas temporalidades en un mismo objeto, como sostiene Didi Huberman (2006) en su observación sobre el carácter difuso de la idea de aura en toda la obra de Benjamin. 
«Todo el presente memoria algún día será.

Entonces mejor empecemos a cambiarlo ya.»

(La asombrosa clase de Zamba sobre la memoria, 2015)

La idea de memoria colectiva es, cuanto menos, escabrosa. Cuando decimos que un pueblo recuerda en realidad estamos diciendo que un pasado ha sido activamente transmitido a la generación presente y que ha sido aceptado como significativo. Hablamos de un movimiento intrincado de transmisión y recepción, una activación del pasado en el presente en función de expectativas futuras (Jelín, 2002; Ricoeur, 2004). La intermitencia en ese movimiento -el olvido en términos colectivos - puede ocurrir de manera abrupta o mediante un proceso de desgaste, adrede o de forma pasiva, por indiferencia o como resultado de alguna catástrofe histórica.

La memoria colectiva, entonces, lejos de ser un reflejo mecánico de los episodios sucedidos, constituye una elaboración compleja en la que participan de un modo ineludible recuerdos individuales y sociales, experiencias pretéritas y vivencias presentes. ${ }^{60}$ Al estudiar esta idea debe considerarse su construcción en el espacio público y los diferentes marcos que inciden en ese proceso (Hallbawchs, 1994; Traverso, 2007 a). Allí, las políticas educativas, las conmemoraciones, los medios de comunicación y la industria del arte y de la cultura cumplen un rol central.

En el capítulo uno hemos analizado el modo en que los gobiernos kirchneristas libraron la batalla cultural con una estrategia que, entre otras cosas, implicó el fomento del papel del Estado como emisor y productor de contenidos. En ese marco, la puesta en funcionamiento, a partir del año 2007, de Canal Encuentro,

\footnotetext{
${ }^{60}$ Esta reflexión acarrea preguntas circundantes a los lazos entre memoria e historia. Se trata de un debate en el que no nos adentraremos porque implicaría desviar por demás el curso de nuestro análisis pero sí vamos a convenir, con Enzo Traverso (2007 b), que estas dos categorías tienen temporalidades propias que se entrelazan de manera constante. La historia es deudora de la memoria y, a la vez, actúa sobre ella porque colabora en su formación y en su orientación. Y en esa intersección entre la historia y la memoria, según Traverso, está la política.
} 
la primera señal de televisión del Ministerio de Educación de la República Argentina, alentó un conjunto de producciones con eje en la revisión del pasado.

Durante el año de conmemoración del Bicentenario esa apuesta se profundizó con el despliegue de series, documentales y largometrajes - algunos de ellos serán analizados en el próximo capítulo-. El programa La asombrosa excursión de Zamba fue el elegido para acercar un relato de la historia al público infantil y favorecer el acercamiento de las y los niñas a un circuito de memorias.

En 2009, un equipo encabezado por Sebastián Mignona (dirección general), Fernando Salem (realización), Eva Lauría (producción general), Nicolás Dardano (dirección de arte) y Gabriel Di Meglio (asesoramiento histórico) ${ }^{61}$ se reunía en las oficinas de la productora El Perro en la Luna para incursionar por primera vez en el formato de la animación, con el fin de producir la temporada inicial de la serie que implicó cuatro capítulos referidos a la Revolución de Mayo de 1810 y a la conformación del primer gobierno patrio, con el Cabildo de Buenos Aires como escenario y con los patriotas San Martín, Moreno, Belgrano, Saavedra, Castelli, French y Beruti como partícipes de la trama. En el marco de un trabajo anterior, Salem había recorrido el país entrevistando a niñas y niños con el objetivo de charlar acerca de sus experiencias en la escuela y sus intereses. Esa tarea casi etnográfica resultó un insumo clave al definir las características de algunos personajes y al conformar la representación de infancia desplegada en la serie.

El protagonista de esta animación es un formoseño de ocho años que vive en la ciudad de Clorinda. Su nombre verdadero es José pero todos lo conocen como Zamba. En cada episodio, el pequeño se transporta a ámbitos espacio-temporales diferentes en los que se topa con figuras relevantes de la historia nacional, latinoamericana e internacional que le permiten conocer $-a$ él y a los espectadores- algunas dimensiones centrales de distintos acontecimientos históricos.

\footnotetext{
${ }^{61}$ La realización contó con el asesoramiento de sociólogos, historiadores, antropólogos y profesionales del campo pedagógico.
} 
En las dos temporadas que sucedieron a esos cuatro capítulos inaugurales lanzadas en 2011 y 2012, ya por la pantalla del nuevo canal infantil Pakapaka- ${ }^{62}$ Zamba conversó sobre educación con Domingo Faustino Sarmiento, viajó a Yapeyú y a la casa de Tucumán, fue partícipe de la batalla de Vuelta de Obligado, visitó el Monumento a la Bandera, resistió en las invasiones inglesas, supo cómo se vivía en el país durante el terrorismo de Estado y luchó junto a los soldados argentinos por las Islas Malvinas.

Con una emisión diaria, repetida en tres franjas horarias, emitida por la televisión pública y distribuida en las escuelas primarias de gestión estatal y privadas, la tira se convirtió en un producto cultural cuyo alcance masivo fue reconocido por sectores antagónicos del periodismo y de la opinión pública (Crivelli, 2015). Desde 2013 y a raíz de ese éxito, los creadores decidieron complementar el formato de capítulos temáticos largos con la plataforma Mundo Zamba, un esquema con contenidos interactivos y capítulos cortos (de 5 a 10 minutos) en donde los protagonistas se relacionan con personalidades del campo de la ciencia, la cultura, el arte, la historia y el deporte. Con el tiempo se sumaron a la propuesta nuevos complementos como un musical itinerante y un parque temático en Tecnópolis que ayudaron a reforzar su popularidad entre niños y adultos, y posicionaron a Zamba como una producción transmedia, adaptable a diferentes formatos y soportes.

A partir del guion y de su tratamiento formal la propuesta despliega símbolos y sentidos vinculados a las ideas de patria, territorio, identidad, independencia, democracia, etcétera. El abordaje de estos asuntos en una producción artística que responde a los parámetros del formato televisivo añade interrogantes acerca de la formalización en el relato de la historia nacional y en la construcción de identidades y memorias. ¿Qué tipo de acercamiento al pasado propuso este material pedagógico difundido mediáticamente?, ¿con qué estrategias artísticas se construyó la narración?, ¿cuál fue el desarrollo poético y ficcional propuesto por sus

\footnotetext{
${ }^{62}$ Los primeros capítulos fueron transmitidos por Canal Encuentro, cuando Pakapaka funcionaba como un segmento dentro de esa emisora.
} 
productores?, ¿qué imágenes sobre la nación se crearon a partir de esa formalización? Allí vamos.

\section{Imágenes de una excursión}

Zamba camina con tranquilidad por un barrio de casas bajas. Lleva puesto un guardapolvo blanco. De pronto se da cuenta de que está llegando tarde a la escuela y comienza a correr. En el trayecto piensa en lo mucho que le gustan el chipá y la tele, en cuánto detesta que su mamá le deje puesto el pijama debajo de la ropa y en que cuando sea grande espera poder convertirse en astronauta. Apura el paso y logra estar en la escuela justo a tiempo para subir al transporte que lo llevará, junto con la señorita Silvia y sus compañeros, a conocer el cabildo de Buenos Aires.

Una vez en el edificio histórico, comienza la visita. La señorita Silvia intenta mantener al grupo controlado al grito de «alumnos síganme por aquí, no toquen nada, todos juntitos», mientras señala los retratos de los próceres de la Primera Junta de Gobierno. Zamba está empecinado en encontrar el cuadro de San Martín, que no aparece por ningún lado. El niño se siente muy aburrido y camina cabizbajo bastante atrás del resto. De pronto su atención se concentra en un cartel que reza «no pasar» al pie de una escalera oscura. Disimuladamente, Zamba se desliza por detrás del cartel y sube la escalera a toda velocidad hasta llegar a un cuarto en el cual el único elemento visible es un magistral sillón de estructura dorada y tapizado rojo que está resguardado con vallas y un aviso de «no sentarse». En un solo salto Zamba sube al sillón y empieza a jugar como si estuviera en el comando de una nave espacial. Justo a su lado hay una palanca negra. El pequeño tira de ella y vemos cómo por debajo del piso se mueve un engranaje muy complejo que enloquece los relojes y expulsa con fuerza a Zamba del sillón, del Cabildo e incluso de la Argentina, y lo hace aterrizar en la España de 1810. 

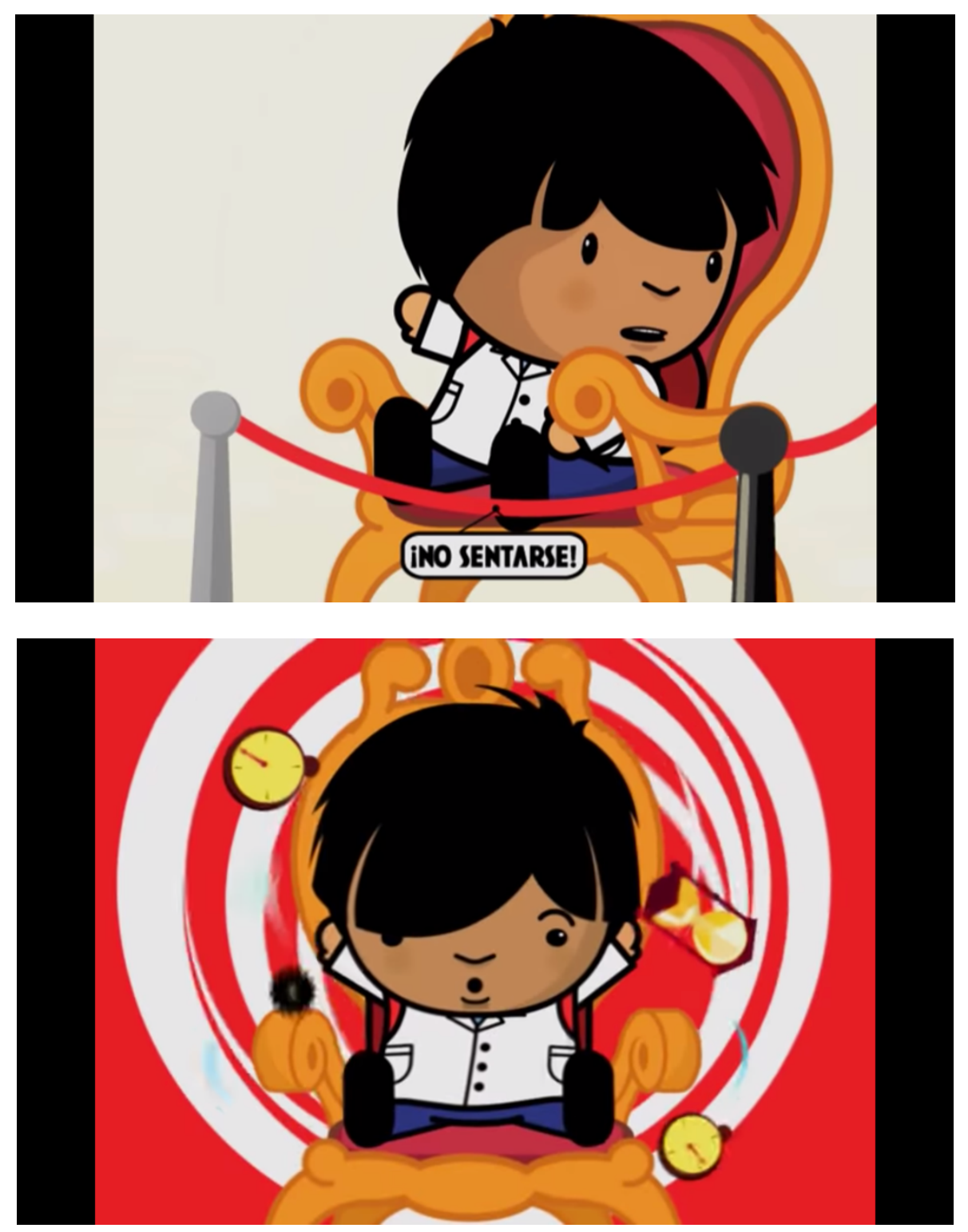

Fotogramas del capítulo «La asombrosa excursión de Zamba en el Cabildo»

Así comienza el primer capítulo de La asombrosa excursión de Zamba (Mignona, 2010a) pero, con mínimas variaciones, esta misma descripción podría valer para cualquiera de los episodios del programa. La trama replica una estructura: el personaje empieza a vivir lo que aparenta ser un día normal de su vida cotidiana como estudiante de la escuela primaria pero de forma inesperada, a partir del 
aburrimiento y del contacto con algún elemento que no debía ser tocado, ${ }^{63}$ se ve embarcado en un insólito viaje al pasado donde es testigo de un conflicto que de algún modo lo involucra como protagonista. Toma contacto allí con figuras centrales de la historia que cumplen la función de introducirlo - a él y a los espectadores- en algunas de las diversas aristas del tema a tratar en cada oportunidad. Todos los capítulos cierran con el retorno de Zamba al presente y, en general, se plantea en el epílogo algún tipo de conclusión o síntesis reflexiva vinculada a los acontecimientos presenciados por el niño.

La producción de este material implicó un asunto difícil de resolver desde la perspectiva del arte: ¿cómo abordar contenidos históricos o sociológicos en contornos narrativos ficcionales? Advertimos que Zamba es un dibujo y que el Belgrano, el Napoleón, la Juana Azurduy o el Galtieri que dialogan con él no son intentos representativos del mundo natural sino animaciones que alcanzan su materialidad a partir de determinadas decisiones artísticas (tamaño, forma, color, escala, encuadre, musicalización). Veamos este asunto en mayor detalle.

La serie fue desarrollada combinando animación digital 2D con animación tradicional para obtener determinados gestos faciales. Esta técnica permitió acelerar la producción al generar movimientos que funcionaron como una matriz a replicar en los distintos episodios, sin ir en detrimento de la expresividad gestual. De todos modos, los dibujos dejan ver que el énfasis de los animadores estuvo puesto más en el tratamiento del color y en la caracterización que en el desarrollo puntilloso de los movimientos, pretendidamente básicos.

Zamba es morocho, tiene piel trigueña, el pelo ligeramente despeinado y un diente roto. Es bajito - para poder escabullirse como Messi, según contó uno de los creadores-, lleva el guardapolvo blanco y la mochila de la escuela casi siempre puestos y empuña una regla. Su amiga y compañera de aventuras, Niña, es una pequeña mulata del siglo XIX, muy inteligente, hija de un esclavo africano y de una

\footnotetext{
${ }^{63}$ Zamba siempre se topa con un objeto que funciona como máquina del tiempo - un eje clásico de la ciencia ficción- y que lo transporta al momento histórico sobre el cual debe aprender en esa clase.
} 
negra liberta, cuyo vestido amarillo resalta su piel morena y su cabellera oscura, siempre recogida en un pañuelo a lunares. Otro personaje que aparece de forma recurrente es El niño que lo sabe todo, un estudiante del curso de Zamba que cumple el papel de «ñoño» en la clase pero ayuda al protagonista a resolver algunas situaciones porque, a pesar de que su disfraz de superhéroe deja bastante que desear, cuenta con un poder muy útil: el conocimiento. Pero tal vez el caso que refleja mejor el cuidado de los realizadores al personalizar a cada protagonista es el de San Martín, el ídolo de Zamba, que se distingue claramente del resto de las figuras por las proporciones: mientras que la mayor parte de los dibujos tienen cuerpos geométricos simples, pequeños y con cabezas exageradamente grandes, San Martín es notoriamente más alto que el resto, su porte es atlético, su espalda ancha y su pecho y pera prominentes, como ocurre con el prototipo del superhéroe.
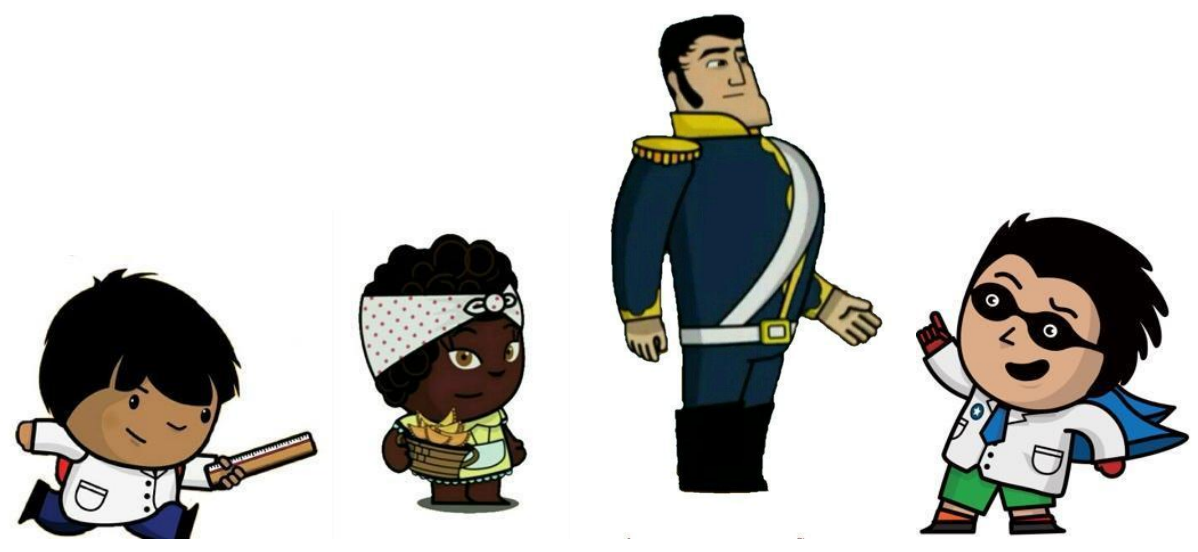

Figuras de Zamba, Niña, San Martín y El niño que lo sabe todo

En cuanto a la imagen sonora, en la serie todo suena en clave de animación. Antes del comienzo de cada episodio, se anuncia el inicio del programa con unos falsos instrumentos de viento hechos con la voz, como cuando usamos las manos en la boca para simular el sonido de una trompeta. Esto le confiere al audio una definición que bascula entre lo deformado, lo equívoco y lo cómico. Algo remite a los juegos de la niñez. 
Como dijimos, los episodios comienzan con una misma secuencia cuyo final varía de acuerdo a la excursión que el niño realiza en cada oportunidad. En esa escena inicial hay dos planos bien diferenciados: ${ }^{64}$ por un lado, una música de fondo que presuponemos que el personaje no escucha y que lo que hace es reforzar un clima de desplazamiento, la idea de que Zamba está en movimiento. Por otro lado, el sono que tiene un lugar inverso al que podría ocupar en una película pretendidamente realista en la que se busque reproducir el ambiente - el viento que hace crujir las ramas del bosque en un día de tormenta-. Aquí, en cambio, cuando Zamba dice que su comida favorita es el chipá aparecen en la imagen tres chipás que él va comiendo como una especie de pacman mientras se escucha un sonido electroacústico que emula a aquél tan característico de los videojuegos. En este sentido, la serie presenta también otros recursos propios del cómic y de los videojuegos: globos con onomatopeyas -icrash!, ipum!, iauch! y iblam!- para acompañar roturas, caídas y golpes, y placas de enlace temporal como «más tarde», «mientras tanto» y «continuará». Sin embargo, cuando Zamba habla su voz suena como la de un niño.

Los personajes centrales suelen ser presentados mediante canciones de distintos géneros que, en muchos casos, ${ }^{65}$ son interpretadas por artistas nacionales de reconocida trayectoria. Encontramos, por ejemplo, «El chamamé del libertador» entonado por Soledad Pastorutti (más conocida como «La Sole»), el «Candombe de Artigas» compuesto por Horacio Fontova, «El bolero de Remedios» en la voz grave de Kevin Johansen y «El rock del gran Manuel» cantado por León Gieco. A estas piezas se suman otras vinculadas a determinados sucesos históricos como «El rap de la independencia» de Fito Páez o la Marcha de San Lorenzo convertida en ska por La Mosca. En algunos casos la parodia es llevada al extremo, como ocurre con la cumbia de Domingo Faustino Sarmiento a cargo del grupo Piola Vago.

\footnotetext{
${ }^{64}$ Según Elena Larregle una distinción fundamental en este sentido es la que nos permite diferenciar la música que forma parte de la escena (diegética) y de la que no lo hace (extradiegética): «La música puede ambientar la/s escena/s u oficiar de elemento que opera sobre cuestiones de corte más estructural, como la continuidad, el ritmo o la forma» (Larregle, 2012, p.66).

${ }^{65}$ En los cuatro primeros episodios la letra y la música de todas las canciones fue obra de Beto Caletti. En las temporadas siguientes la tarea pasó a manos de Leo Sujatovich y de Ezequiel Zilberstein y allí comenzaron las colaboraciones de diferentes artistas en cada episodio.
} 
En buena parte de los episodios los protagonistas cantan y despliegan secuencias coreográficas, lo cual remite a la estructura de la comedia musical. Las melodías resultan sencillas de recordar y las letras de los temas aparecen en pantalla como subtítulos. Sumado a esto, en una de las pestañas de la plataforma digital, bajo el rótulo de «Karaoke Zamba», es posible acceder a una selección de canciones de la serie. Allí podemos ver y escuchar parte de la banda sonora del programa, a modo de pequeños videoclips independientes del capítulo en el que fueron incluidos originalmente.

Por lo tanto la música, además de desempeñar su función en el enlace entre escenas o en la anticipación de lo que está por ocurrir, cumple el rol de remitir a otras imágenes sonoras que, a su vez, habilitan asociaciones con imágenes visuales populares. Ejemplo de ello es la elección de la música del largometraje Misión imposible para acompañar la hazaña emprendida por Zamba en su intento de entrar al Cabildo sin ser detenido por un guardia patricio (Mignona, 2010b) o de una prototípica «música de terror» como anuncio de la llegada de «los malos» - los ingleses en la excursión a la Guerra de Malvinas, la Junta Militar en el episodio sobre la última Dictadura, etcétera-: en el plano extradiegético, una secuencia armónica en tensión, ejecutada por instrumentos orquestales, sobre un ritmo lento y regular cuyo desenlace es un ataque de mayor densidad sonora y, en el nivel diegético, la recreación de un sono fantasmal, aullidos de lobo, viento y gritos lejanos (Mignona, 2012a).

En el mismo sentido funciona el marco sonoro y visual de una escena en la que el personaje de Niña se convierte en conductora del programa «Quiero un marido revolucionario» para encontrarle una pareja a María de los Remedios de Escalada, la «hija predilecta de una aristocrática familia criolla» a partir de la presentación de tres candidatos que aparecen en escena tras la ovación de los aplaudidores y circundados por un corazón: el guapo, arrogante, fanático del arroz con leche y de las reuniones secretas, Carlos María de Alvear, el impulsivo Bernardo de Monteagudo y el joven de «treinta y cuatro años, tímido con las chicas pero valiente y temerario en el campo de batalla», Don José de San Martín (Mignogna, 
2011b, 00.11.31). En la escena se escucha de fondo una de las típicas piezas musicales de los programas de entretenimiento norteamericanos - al mejor estilo big band de jazz- también usadas por algunos «programas del corazón» argentinos que han importado sus formatos de los reality shows de Estados Unidos.

Podemos arriesgar que quienes pensaron las imágenes sonoras y visuales para Zamba se empeñaron en buscar que esas imágenes resulten familiares. Y esto vuelve a poner sobre la mesa la relevancia de completar el análisis formal del material con la mirada puesta en las condiciones germinales de su producción: la premisa de convertir la serie en un producto para el consumo masivo, permeado por los códigos televisivos y orientado a un público específico (Belinche Montequín, 2019). ${ }^{66}$

\section{Corrupciones}

La puesta al aire del programa reavivó interrogantes referidos al vínculo siempre candente entre historia y divulgación. Hemos dicho que Zamba se acerca al pasado y a los relatos históricos que han sido durante más de un siglo patrimonio de las instituciones educativas. Y esa aproximación, resulta obvio, no es neutral. En los episodios de las primeras entregas y en buena parte de los segmentos nuevos es posible reconocer un rasgo común: son producciones que construyen sentidos en torno a la nación, que proponen acercamientos alternativos a la historia, que visibilizan ciertas memorias y dan cuerpo a otras.

Lejos de rehusar de esa condición los hacedores del material decidieron asumirla como un elemento estructurador a la hora de reseñar públicamente el proceso de factura de la serie, tal como puede leerse en las declaraciones de Verónica Fiorito, una de las fundadoras de Pakapaka:

\footnotetext{
${ }^{66}$ Algunas de las reflexiones incluidas en este apartado se originaron en un artículo que realicé en el marco de uno de los seminarios del Doctorado en Artes y que fue posteriormente publicado en la revista Arte e Investigación. Ver: Belinche Montequín, M. (2019). Una que sepamos todos. Imágenes sonoras en La asombrosa excursión de Zamba. Arte E Investigación, (15).
} 
Nosotros somos el Ministerio de Educación. Y Zamba es una política del Ministerio. Decisiones como hacer más capítulos, desarrollar los parques temáticos o producir un musical sobre la vida de San Martín provienen de la máxima autoridad del Ministerio. Se trata de una decisión política. Con una libertad de trabajo inmensa. Una libertad que, por otra parte, nos obliga a cuidar al personaje. Porque aunque muchas veces llevamos las cosas a un límite casi en el borde de lo permitido, nos cuidamos mucho de no cruzar ese límite porque sabemos que su destino, primero, es el aula. En el caso de las efemérides, el 25 de Mayo, el Cruce de los Andes, la Creación de la Bandera, se sucedieron casi naturalmente, pero cuando tuvimos que ponernos a trabajar con Malvinas discutimos mucho: Zamba funcionaba muy bien en el siglo XIX pero teníamos dudas sobre cómo sería su salto al siglo XX; una cosa es participar en el Combate de San Lorenzo y otra agarrar un FAL e ir a Malvinas, una guerra muy reciente además. Pero hicimos «Malvinas» y después también «Dictadura», otro gran reto (Rojas, 2013).

En un sentido similar, tanto Mignona como Salem se han ocupado de señalar en reiteradas oportunidades el modo en que el grupo lidió con la certeza de estar generando un contenido con fines educativos y cómo esa premisa fue guía al momento de tomar algunas decisiones acerca de los personajes, por ejemplo, la ingenuidad y el asombro de Zamba y su modo desprejuiciado de aproximarse a la historia: el niño viaja siempre desinformado, vive las aventuras en carne propia y sin saber lo que va a pasar después. Interroga al pasado y muchas de sus preguntas quedan sin resolver.

Un sello en el mundo de estas aventuras asombrosas es la desacralización que se propone sobre los exponentes más relevantes de la historia. Todo dejo de solemnidad en el trato con los próceres es descartado y reemplazado por la actitud desprejuiciada del niño que, en la mayor parte de los casos, se topa con ellos sin saber siquiera quiénes son. Tal característica queda planteada desde el vamos, en el primer capítulo de la serie. Al llegar a 1810 Zamba confunde a Napoleón con San Martín y cuando el militar, muy disgustado, se presenta — «Emperador de los franceses, rey de Italia, conquistador de Europa y futuro dueño de todo el mundo. ¿No has escuchado de mí?, ¿de mi imperio?, ¿de mis seis años en el campo de batalla?, ¿no has escuchado hablar de Napoleón Bonaparte?»- el niño solo atina a decir «ahhh el que estaba loco» (Mignona, 2010a). Este recurso paródico se repite a medida que 
aparecen los distintos personajes: Zamba les pide autógrafos pero en verdad no los distingue. Castelli es un engreído que habla con voz de locutor, a Moreno todo el mundo lo confunde con Belgrano, French y Berutti están pegados como siameses y se completan las frases entre sí, don Juan Larrea es ansioso e hiperquinético, Rodríguez Peña solo quiere conversar de dinero y todos se adormecen cuando Juan José Paso comienza a dar sus larguísimos discursos en un tono monótono y carente de emoción.

La profanación no se detiene únicamente en el inventario de estas personalidades sino que se extiende a sus acciones más destacables. Cuando la constitución del gobierno patrio está en peligro Zamba insta a los próceres a hacer algo porque de lo contrario nadie les va a hacer monumentos, las calles no van a tener sus nombres, las revistas escolares no van a traer sus figuritas y nadie va a querer hacer dibujos animados sobre ellos. También es Zamba quien le da la idea a Belgrano de usar los colores celeste y blanco como insignia de la patria y quien menciona por primera vez en el pasado el nombre Argentina. El cabildo abierto logra realizarse con éxito porque Niña, Zamba, French y Berutti elucubran distintas trampas para que quienes van a votar al Virrey Cisneros no puedan presentarse $-\mathrm{y}$ la moralidad de estas hazañas es cuestionada por Cornelio Saavedra en el epílogo del episodio-. Juan Manuel de Rosas accede a resistir la invasión anglo-francesa en la batalla de Vuelta de Obligado después de ser persuadido por Niña, que apela a robustecer la vanidad del caudillo, y por un San Martín ya viejo que le hace una videollamada y le ofrece su sable para convencerlo (Mignona, 2010a, 2010b, 2010c, 2010d, 2011c). Los ejemplos abundan. 


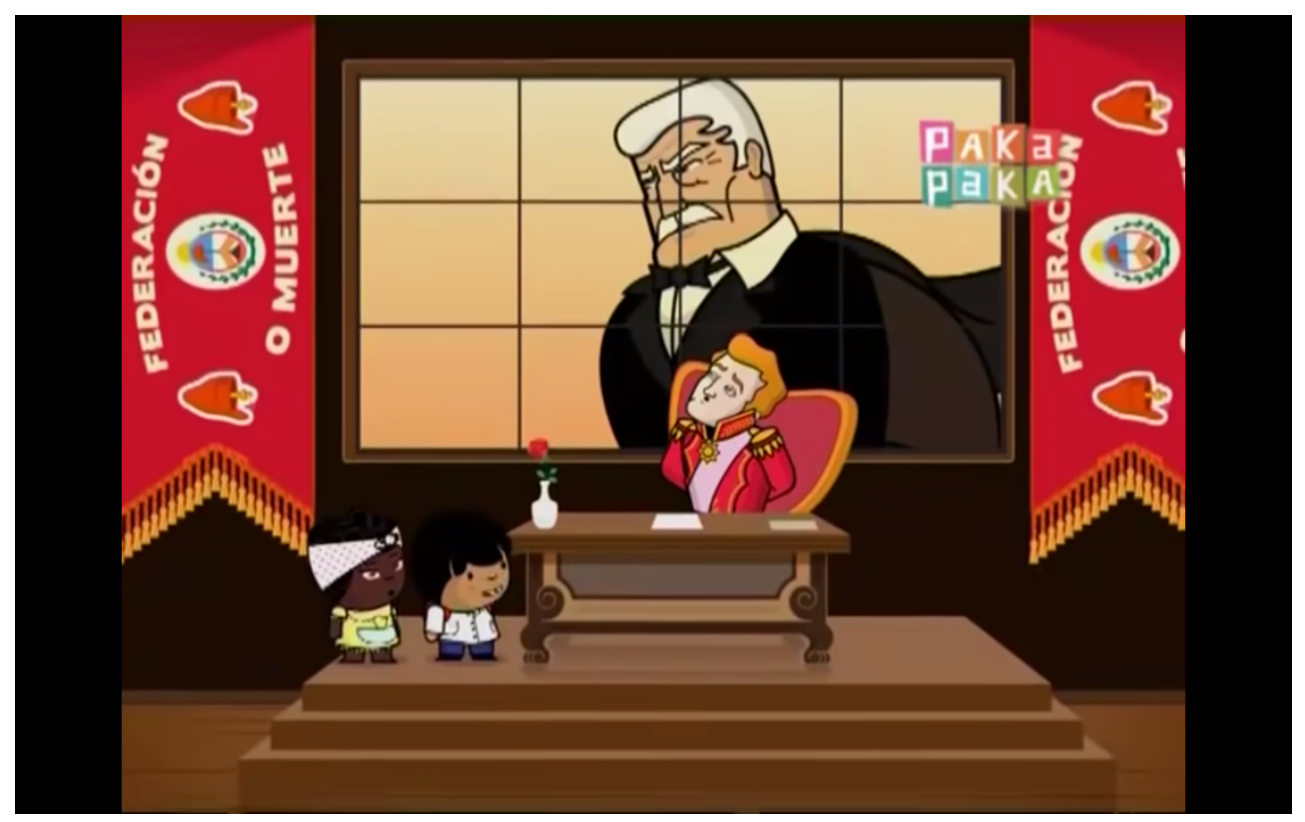

Fotograma del episodio "La asombrosa excursión de Zamba en la Vuelta de Obligado»

En la misma clave se aborda el capítulo en el que el protagonista presencia las discusiones que signaron los orígenes del sistema educativo argentino y de la escuela como institución moderna: la excursión a la casa de Sarmiento. La ironía y la metáfora permiten allí que las contradicciones se enuncien como posibilidades simultáneas.

En lo que respecta a la figura de Sarmiento, por un lado, se corrompe su imagen impoluta y aparentemente imperturbable: ha tenido una infancia complicada, no siguió el camino que sus padres imaginaron para él, admite que ha cometido errores, es capaz de usar ropa deportiva y de entonar un rap o una cumbia, y llega a confesar que alguna vez faltó a la escuela. Por otro lado, el personaje es enaltecido como el principal creador de la educación pública y como el ideólogo de la estructura del sistema educativo nacional. Al tiempo que se objeta su mirada acerca de la barbarie, del federalismo, de los caudillos, del uso de la fuerza y su devoción por Europa se refuerza la caracterización de su estampa como padre del aula para todos.

Como sabemos, en el modelo sarmientino el alcance de ese todos era limitado. En palabras de Adriana Puiggrós (2012) «Sarmiento promovió el sistema educativo más democrático de su época, al mismo tiempo que realizó una operación 
de exclusión de los sectores populares. A la escuela pública del imaginario sarmientino concurría un sujeto abstracto que jamás llegó a existir» (p. 69). Según el diagnóstico del prócer los indios y los gauchos que representaban una porción importante del pueblo latinoamericano eran considerados bárbaros por naturaleza y quedaban fuera de la población educable.

Los realizadores del capítulo no se privaron de mostrar esas tensiones. Aun cuando en la cumbia final se subraya el carácter democrático de la educación propuesta por Sarmiento, a lo largo de la trama aparecen huellas de su preocupación por definir el tipo de civilización que la nación necesitaba: blanca, laboriosa, racional, científica y moldeada a imagen y semejanza de las grandes potencias. Y, una vez más, esas señales son apuntadas mediante el humor. En Chile, a donde Sarmiento ha ido exiliado para combatir desde allí a los federales, el educador canta un vals mientras Zamba toca el acordeón vestido como un niño parisino:

Oh lalá, oh París, algún día mi país será igual, igual a ti París. Qué elegante es el francés, es tan culto como el inglés, en cambio aquí es lo que ves: indios sin nada en los pies [...] Desde Chile escribiré, con mi diario educaré, con balas combatiré, del tirano me reiré. Indios, gauchos, iun horror!, iesta gente es de terror! Los lidera un ignorante que se cree muy importante pero es un dictador. El progreso es impensable sin la pluma y sin el sable. Educación y algún cañón para una gran nación. Las ideas no se matan más los federales sí (Mignogna, 2011a, 00.08.31).

El pequeño intenta leer con mucha dificultad la frase On ne tue point les idees, ${ }^{67}$ y luego increpa sin mayores rodeos al prócer: «¿Por qué lo escribe en francés Sarmiento?, así no lo va a entender nadie» (Mignogna, 2011a, 00.08.13), en un guiño que nos lleva a pensar que los realizadores trabajaron con la referencia de un todos de márgenes más amplios que los que Sarmiento definía para su universo educable.

Así, la utilización de los recursos musicales y visuales de modo extemporal, donde se recurre primero a una especie de rap presentado como videoclip y, después, a una cumbia que remite a la cantidad de escuelas creadas por Sarmiento -representadas en un mapa por bolitas de colores que luego se transforman en un

67 En español: «Las ideas no se matan». 
pelotero gigante en el cual los protagonistas se revuelcan-, genera un distanciamiento que vuelve más compleja la percepción y permite construir, alrededor de una figura que permaneció durante mucho tiempo cristalizada, un personaje atractivo, con fisuras. El guion proyecta a la educación como un hecho político, propone pensar los orígenes del sistema educativo en términos controversiales, muestra los sectores y las ideas en pugna, acorta distancias y permite aproximar estos asuntos al presente (Belinche, Pilaría \& Ward, 2016).

\section{Malvinas, la nación imaginada}

A partir de la segunda temporada del programa el salto al siglo XX generó, como bien imaginaba el equipo productor, debates que se reflejaron tanto en las repercusiones como en la formalización misma de los episodios. Revisemos un caso particularmente controvertido. ${ }^{68}$

En La asombrosa excursión de Zamba en las Islas Malvinas, el niño se ve embarcado en un viaje al archipiélago en medio del conflicto bélico de 1982 donde es testigo de la confrontación entre las tropas británicas y los soldados argentinos. Conoce allí a un aviador llamado Chispa, a un niño que habita la colonia, a un general británico, a un combatiente argentino, Sapucai, y a Leopoldo Fortunato Galtieri, quien aparece fugazmente a lo largo de la trama y cuyo nombre nunca es mencionado. Estos personajes introducen a Zamba en distintos aspectos de la cuestión Malvinas: el «descubrimiento» de las islas por parte de los españoles y las disputas europeas por el territorio a partir de entonces, la sucesión del archipiélago a partir de la independencia de España, la invasión inglesa de 1833, la guerra en el contexto del terrorismo de Estado, la caída de soldados de ambos bandos y la derrota

\footnotetext{
${ }^{68}$ Cabe mencionar que históricamente las Islas Malvinas ocuparon un lugar privilegiado en el proceso de nacionalización que cimentó el sistema educativo argentino y que fueron piedra de toque en la composición de la escuela de la patria. Cuando comenzaron a ser tematizadas las relaciones de dependencia con el imperio británico, la cuestión Malvinas apareció definitivamente en las aulas y su lugar en las áreas curriculares y en los rituales escolares creció junto con los reclamos diplomáticos y la centralidad que el tema adquiría para los ciudadanos.
} 
argentina. El capítulo concluye con una reflexión pacifista que reivindica la soberanía sobre las islas en la cual, en tiempo presente, Zamba se reencuentra con aquél soldado argentino al que creía muerto en Puerto argentino y entabla con él una conversación que deja abierta la posibilidad de una recuperación futura del territorio y acentúa la necesidad de la unidad latinoamericana para tal empresa (Belinche Montequín, 2018). ${ }^{69}$

A lo largo del episodio, las canciones y los diálogos de los personajes refuerzan la idea de que la disputa por la soberanía en las islas no debe dirimirse mediante la guerra porque esta «siempre sale mal». No obstante, en lo relativo al conflicto bélico, el hilo argumental fluctúa entre el repudio y la reivindicación heroica, como podemos apreciar en la letra de la melodía que es entonada por el soldado Sapucai - en la voz de Coti Sorokin - y en las imágenes que ilustran aquello que se enuncia: «La guerra ya comenzó, al miedo hay que vencer, aunque tal vez sea mejor dejarlo todo y volver. La patria al fin respondió al invasor imperial “iVaya al frente con valor! Total yo me quedo acá"» (Mignogna, 2012b, 00.08.50). Mientras suenan estas estrofas se ve en pantalla a Galtieri y a Margaret Thatcher manejando dos máquinas en las que ingresan ciudadanos vestidos con ropa de calle y salen, a modo de producción en serie, pequeños combatientes. Los soldaditos son lanzados por la máquina a una cinta transportadora y terminan cayendo al vacío -algunos se lanzan voluntariamente- . A continuación, la secuencia intercala una imagen de muchos combatientes argentinos enfrentándose a un único enemigo que parece rendirse con los brazos en alto, - mientras la canción arenga «iVamos peleemos contra el inglés, tenemos que echarlos de una vez!»- con otra en la cual se ve a Galtieri sosteniendo un televisor que emite esta misma escena de victoria argentina mientras levanta un pulgar en señal de aprobación. Finalmente, volvemos a las islas donde la correlación

69 Estas reflexiones recuperan un análisis que elaboré en el marco de las sesiones de trabajo del Proyecto Promocional de Investigación y Desarrollo «Memoria y violencia en el siglo XX», las cuales fueron parte de mis tareas como becaria doctoral. Ver: Belinche Montequín, M. (2018). El asombroso mundo Malvinas. Imágenes del archipiélago en la propuesta de Pakapaka. En Kahan, E. N., Cueto Rúa, S. y Rodríguez, L. G. (Coords.). (2018). Memoria y violencia en el siglo XX : Horizontes de un proyecto de investigación. La Plata, Argentina : Universidad Nacional de La Plata. Facultad de Humanidades y Ciencias de la Educación. 
de fuerzas cambia con la llegada de un buque enorme y repleto de soldados británicos que lanza un misil y hace volar todo por los aires al compás de la música: "“iVamos ganando!" dicen en TV. Pero no se nota, aquí hay mucho inglés, aquí hay mucho inglés» (Mignogna, 2012b, 00.09.30), en lo que podemos interpretar como una crítica al rol desplegado por los medios de comunicación durante el conflicto bélico y a su proclama en favor de la euforia patriótica y exitista propugnada por el régimen dictatorial.
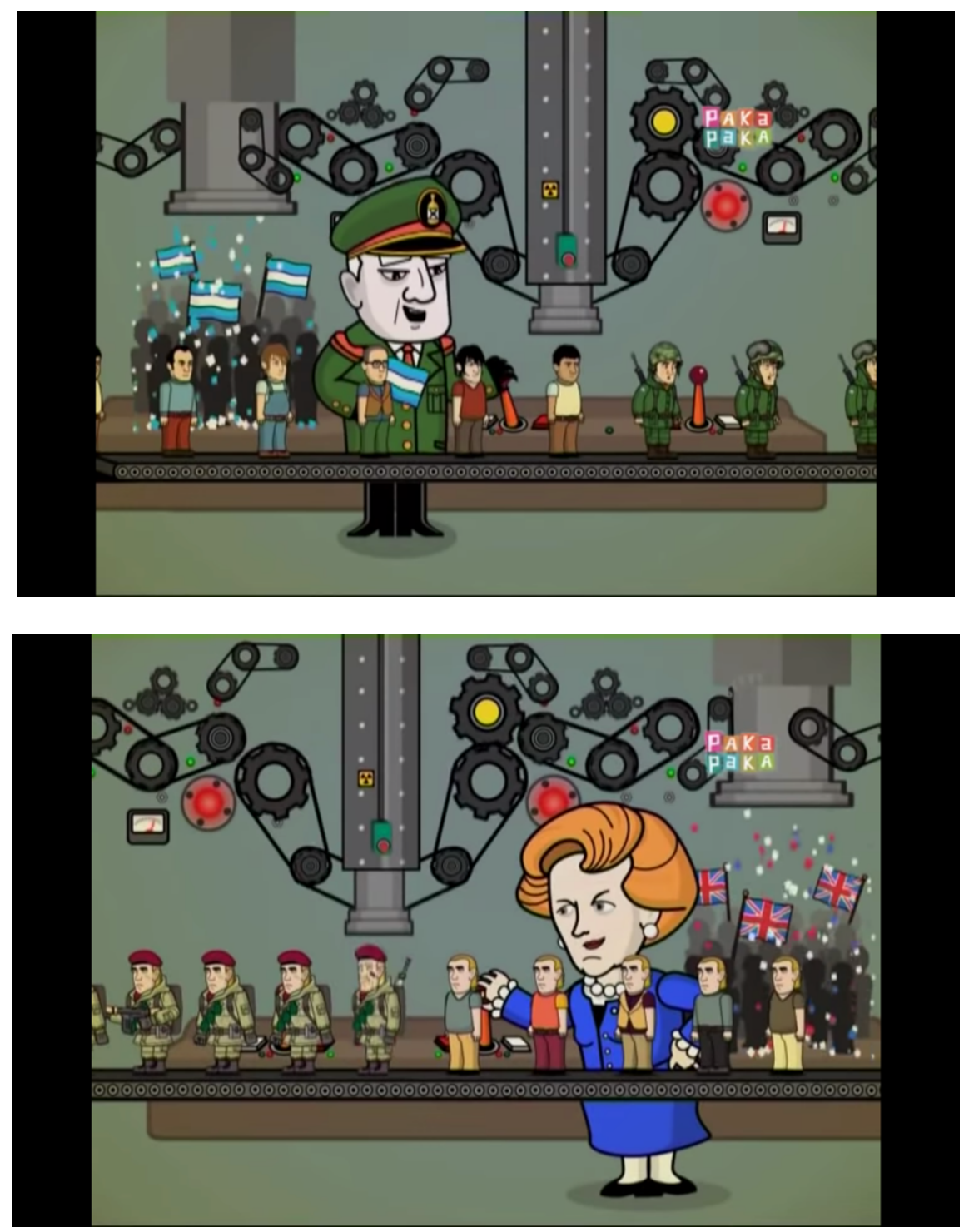

Fotogramas del capítulo «La asombrosa excursión de Zamba en las Islas Malvinas» 
A medida que avanza el episodio, los diálogos y las imágenes ponen en primer plano otros aspectos negativos del modo en que se desplegó el conflicto de 1982: se muestra la inferioridad de condiciones de la tropa argentina con respecto a la británica, las condiciones de vida precarias de los soldados en el archipiélago y el sinsentido de la guerra bajo el mandato caprichoso de un dictador caricaturizado. Sin embargo, en igual medida, la trama desliza una descripción de la guerra como gesta patriótica y de sus combatientes como héroes sin fisuras, morigerando de algún modo los alcances de aquella impugnación.

La identificación de los soldados como mártires capaces de morir por su patria es un asunto que merece un tono especialmente cuidadoso si tenemos en cuenta que un sector de los mismos ex combatientes rechaza el mote de héroes, desbrozando el hechizo de dejarse llevar por el lugar común. Desde ya, si se considera el coraje con el que los soldados, en su mayoría jóvenes inexpertos, enfrentaron las pésimas condiciones en las que fueron a combatir, la desazón creciente ante el devenir de los hechos desde el cenit hasta el derrumbe, el haber ido desarmados no solo en términos propiamente bélicos sino desarmados de toda estrategia, de toda contención política- a resistir la soledad, la distancia, el hambre, el frío y, en muchos casos, la muerte propia o de sus compañeros, indudablemente, la calificación hace justicia. Pero del mismo modo iguala, descuida parte de las grandes contradicciones humanas y dificulta la distinción de responsabilidades: represores y torturadores enfrentaron también las balas del enemigo. En el episodio, la presencia de un Galtieri cuya tiranía es desdibujada por la torpeza y la borrachera no llega a proyectar esa tensión, aun cuando en la coda final se lo describa explícitamente como un tirano y un dictador que ideó la guerra «para distraer al pueblo».

La compleja tarea de decir mucho en poco tiempo fue resuelta por los autores de la serie en muchas oportunidades apelando a la síntesis poética. En este capítulo, sin embargo, la sobre-argumentación y el exceso de simplicidad menoscabaron, en alguna medida, la búsqueda metafórica en pos de favorecer la direccionalidad hacia el efecto deseado: generar empatía con la idea de una territorialidad recuperada. El afán de volver todo más claro suele ser la zona en la que el arte se distingue de la 
información (Piglia, 2012). Al abordar cuestiones que implican una carga emocional de enorme densidad como la muerte, la soledad, el dolor, la desaparición o la guerra, la propensión al estereotipo minimiza muchas veces la hondura intrínseca a estos sucesos y el contenido es mostrado de manera literal o es exagerado apelando a la utilización de recursos, de imágenes y de palabras largamente transitados.

Se trata, desde nuestra perspectiva, de un capítulo que despliega estereotipos visuales, musicales, narrativos y poéticos en mayor medida que otras entregas de la serie, en las cuales ese recurso fue usado como un punto de partida, para luego reconfigurarse mediante la ironía y la metáfora. No obstante, el análisis de este material resulta estéril si no se lo completa a la luz del debate intelectual y político en torno a Malvinas que tuvo su punto más álgido en los meses circundantes al trigésimo aniversario de la Guerra y dentro del cual el programa se vio inmerso.

Después de un largo período de desmalvinización en los medios, en las escuelas, en las universidades y en las fábricas, de un paulatino deslizamiento del tema al interior de los sectores directamente involucrados y de su desaparición de la agenda política (Guber, 2001) el escenario político consolidado con los sucesivos gobiernos kirchneristas volvió a instalar nuevamente el afán de integración de las Islas al territorio nacional como tema de la agenda política, ${ }^{70}$ en una línea de continuidad con otras decisiones tomadas por Néstor Kirchner, Cristina Fernández y sus equipos de gestión en lo que atañe a la política exterior.

La iniciativa oficial recibió el apoyo de quienes desde el retorno a la democracia denunciaban las violaciones cometidas por las cúpulas militares durante la Guerra y encontraron en la política de Derechos Humanos delineada por el kirchnerismo, en la crítica a las Fuerzas Armadas de la Dictadura y en el impulso a los juicios por crímenes de lesa humanidad, una posibilidad de rearticular sus

\footnotetext{
${ }^{70}$ La nueva configuración de este debate en la escena pública fue acompañada por la búsqueda de un cambio en su abordaje dentro del espacio escolar. La nueva Ley de Educación Nacional 26.206, sancionada en el año 2006, ubicó la problemática dentro de los contenidos curriculares comunes y el Ministerio de Educación de la Nación le otorgó centralidad colocándola como uno de los ejes que definieron su política orientada a los Derechos Humanos, a la historia reciente, a la restitución de derechos y a su ampliación.
} 
demandas. ${ }^{71}$ Simultáneamente, sectores con visiones más esencialistas defendieron la causa nacional desde un alegato patriótico semejante al de las facciones conservadoras, sin reparar en los móviles internos del conflicto (Lorenz, 2006). En las antípodas se encontraron tanto quienes abiertamente preferían que las Malvinas fueran inglesas $^{72}$ como aquellos que desestimaron el tema de la soberanía por considerarlo de escasa significación frente a otros asuntos de trascendencia más abstracta y universal: las libertades individuales o la legitimidad de la autonomía de los habitantes de las Islas. ${ }^{73}$

De este modo, las posturas ante el discurso y el accionar político kirchnerista sobre la cuestión Malvinas bascularon entre su reivindicación en tanto asunto de interés para el conjunto del pueblo y de la región, el repudio a la supuesta magnificación del tema en pos del impulso de un clima de agitación nacionalista, la apertura a interpretaciones subalternas y contra-relatos del pasado y las simplificaciones.

En ese marco, la línea argumental de algunos intelectuales especialistas en la temática devino de la siguiente manera: era necesario pensar la cuestión Malvinas

\footnotetext{
${ }^{71}$ A partir de la llegada de Néstor Kirchner al poder y en adelante, la tensión entre ex combatientes que impulsaban denuncias contra militares por estaqueamientos durante la guerra y sectores de veteranos que reivindicaban un discurso belicista, pareció dirimirse a favor de los primeros. La Comisión Nacional de Ex Combatientes que desde su creación durante el menemismo había sido conducida por veteranos ligados a los carapintada pasó a estar intervenida desde el año 2003 y en 2012 comenzó a ser presidida por Ernesto Alonso, uno de los más nítidos impulsores de los juicios contra militares señalados como torturadores en las Islas.

72 Sin desconocer las mutaciones de algunos posicionamientos y los matices entre actores heterogéneos es posible enlazar esta orientación a un ideario que, en términos generales, ha sido proclive a la sumisión de la Argentina ante los organismos internacionales, desde el liberalismo del siglo XIX pasando por los pactos con los sucesivos gobiernos británicos, la concepción de una matriz económica basada en la exportación de materias primas y hasta las políticas de mercado en un sentido ortodoxo.

${ }^{73}$ Esta es la posición expresada en el documento de reflexión «Malvinas: una visión alternativa» presentado por un grupo de periodistas e intelectuales argentinos semanas antes del 30 aniversario de la Guerra. En dicho documento, los autores advierten la inexistencia de una crítica profunda al apoyo social que acompañó la guerra de Malvinas y repudian el «clima de agitación nacionalista» impulsado por dirigentes tanto oficialistas como de la oposición «quienes se exhiben orgullosos de lo que califican de "política de Estado"».
} 
sin convertir la disputa en una compulsa que reprodujera los peores rasgos esencialistas del nacionalismo popular o procreara de manera mecánica una impugnación a la postura del gobierno kirchnerista, asimilable a cualquier otra réplica vinculada a su cosmovisión de la etapa política. La narrativa se orientó a una suerte de llamado a la complejidad y a la moderación, desarmando el núcleo de oposición soberanía nacional versus derechos de autodeterminación bajo un paraguas analítico que cuestionó un aspecto de grado más que de sustancia: la exageración, la sobredimensión. En un caso lo sobredimensionado era el nacionalismo, la intolerancia, cierta nostalgia patriótica que deformaba la mirada sobre la historia, carecía de complejidad y omitía verdades. En su reverso, la crítica al sector que minimizaba la importancia de Malvinas como un rasgo simbólico de la soberanía se alojó más en una posible alineación mecánica al anti-kirchnerismo que en un análisis pormenorizado de la línea de razonamiento que exhortaba a respetar la autodeterminación de los isleños y relativizaba la significación que podían tener las Islas en el presente.

Al respecto, cabe decir que Malvinas era en 2012 y es hoy una fortaleza. El destacamento inglés que opera allí tiene un poder de fuego superior al total de las Fuerzas Armadas argentinas y podría tomar toda la Patagonia sin solicitar ayuda a Gran Bretaña. No se trata de una estigmatización sobre el país de Shakespeare, Newton, Dickens o Los Beatles. Es claro que Inglaterra ha dado al mundo buena parte de su progreso. Ha sido, también en nombre de ese mismo estandarte, un país históricamente imperialista, que propició la Guerra de la Triple Alianza, acompañó a Estados Unidos en las matanzas en Irak y Afganistán y mantiene bajo su control colonias en Anguila, Bermudas, Islas Vírgenes, Islas Caimán, Gibraltar, Montserrat e Islas Turcas y Caicos, entre otras.

Por otra parte, el argumento que caracteriza a las Malvinas como unas islas lejanas, rocosas y estériles que fueron pobladas cuando no existía la nación y que, por lo tanto, otorga derechos a quienes desde Inglaterra vinieron a habitar las áridas tierras perdidas en los confines del mundo, parece desconocer que los hombres y las mujeres no son solamente animales racionales sino que, como sostiene Enrst Cassirer 
(1944), lo que atañe específicamente a la realidad humana es lo simbólico y que, por lo tanto, las Islas no pueden ser pensadas únicamente como un pedazo de tierra sino que deben ser entendidas a partir de aquello que las trasciende, en cuyo devenir hay supervivencias del pasado y donde, por otra parte, se expresa uno de los peores casos de colonialismo vigentes en el siglo XXI, que ha merecido el reclamo mayoritario de la comunidad internacional, incluso de países que comparten intereses estratégicos con el imperialismo inglés.

Aun cuando podamos discutir y complejizar la explicación ofrecida por los autores de Zamba sobre la legitimidad del reclamo de soberanía, es claro que al hablar de la cuestión Malvinas no hablamos de una cuestión menor exacerbada por un neo nacionalismo chauvinista. La guerra, la explotación de los mares argentinos, la violación de derechos humanos y de tratados internacionales, la militarización del Atlántico Sur y la unidad simbólica, cartográfica y cultural, constituyen asuntos de interés para el conjunto del territorio sudamericano.

El capítulo presenta zonas de debilidad porque, lo hemos dicho, no existen por un lado los contenidos sociales y por otro los abordajes neutros. Ambas dimensiones se atañen para conformar la totalidad e intervienen, en este caso, en las representaciones sobre el tema que se pretendió divulgar con un sentido educativo. Aun así, recordemos, la estructura narrativa del episodio responde a una decisión de orden sintético que elige tomar postura respecto de ciertos acontecimientos de la historia. El personaje de Sapucai no busca formular una tesis académica sobre la autodeterminación de los pueblos y la alternancia pendular entre los derechos adquiridos por principio de integridad territorial y las posibles huellas de otros derechos alcanzados a lo largo de dos siglos de penetración en el continente. Lo que quiere Sapucai es dejar en claro que las Malvinas son argentinas, que le asiste el derecho soberano. Lo hace de manera clara, por momentos literal y hasta burda. Pero si profundizamos el análisis y nos distanciamos para agudizar la mirada podremos acaso advertir que ciertos cuestionamientos dirigidos a esta producción no fueron estéticos ni discursivos sino, centralmente, políticos. 
La recuperación de Malvinas, acaso, será consecuencia de una obstinación histórica que va a requerir el acompañamiento de políticas educativas y culturales tangibles, constantes, capaces de despejar la bruma que como una metáfora envuelve a las Islas, a su tratamiento académico y a su dimensión simbólica. Para ello será imprescindible detenerse, no sólo en el intento por develar la verdad de la historia, si no en hacer evidentes estereotipos y artificios acerca de su narración. Será cardinal conceder nuevas imágenes dialécticas e inventivas que entretejan sentidos, que liberen síntomas, que habiliten incertezas - muchas veces valiosas cuando del acto educativo se trata-, que abran el tiempo. Entonces, tal vez podamos aceptar con Mignona que «Zamba no es el final de las cosas sino el principio de las preguntas» (Tenaglia, 2013).

\section{Volver al futuro}

Si la memoria se congela en su propia capacidad instrumental y no nos permite entender las imágenes del ahora debilita su condición. Así lo explicó Abby Warburg. Su tema casi obsesivo y curiosamente pocas veces rescatado -aquí le debemos a Huberman el reconocimiento a un trabajo termita - fue la relación entre el pasado y el presente o, mejor dicho, el sentido del pasado en el presente.

Esta preocupación también parece haber tenido peso en la factura de $L a$ asombrosa excursión de Zamba. Los productores de la serie decidieron recuperar la mirada histórica desde la imagen, con sus potencialidades tanto para descomponer una lectura unidireccional de la historia y para poetizar la memoria como para estereotipar y simplificar ambas. Esa puja entre literalidad y síntesis poética o entre estereotipo y metáfora subyace en toda la tira y su resolución se renueva en cada capítulo. Las elecciones visuales y sonoras no quedan exentas de esta tensión que se dirime al interior mismo de cada pieza cuando, por ejemplo, una letra recorre lugares muy transitados y esperables pero es cobijada por un fondo de mayor hondura compositiva, por una interpretación que vuelve más ambiguo el lugar común o por una secuencia de animación que permite conjugar al unísono tiempos distantes. 
En la trama temporal de esas excursiones un hiato genera dentro del presente una idea de pasado. Pero a la par, y tal vez aquí resida lo más sugestivo, ese efecto de extrañamiento opera en una doble direccionalidad y aquella ruptura produce, también, una irrupción del presente en tiempos pretéritos. Por esas concesiones que solo habilitan los sueños y el arte, Zamba retorna a un pasado que no es el suyo -o que solo lo es en términos colectivos-, se despliega en él, lo interroga y lo recicla hasta convertirlo, mediante artificios, en parte de un presente ensanchado $y$ verosímil dentro de esa conciencia imaginada.

Como hemos analizado, esos intentos de ensanchamiento le han valido a la serie un lugar en el centro de cuestionamientos mediáticos y académicos que, aunque hayan logrado enmascararse detrás de querellas estéticas o discursivas, tuvieron un porte fundamentalmente político. En la misma línea podríamos indagar acerca de las transformaciones del programa a partir del triunfo de Mauricio Macri y su gabinete en las elecciones de 2015. El desmantelamiento del parque temático en Tecnópolis, la repetición de una selectiva lista de episodios viejos en la programación de Pakapaka, la postergación por casi un año de nuevas emisiones y el reemplazo del asesor histórico de la tira plantean un bosquejo más que sugerente para futuros derroteros que vincularán, probablemente, esas imágenes agónicas con las incógnitas abiertas por el retorno de un Zamba victorioso el último 25 de mayo de 2020. 
CAPÍTULO $5 \quad \vdots$ LOS QUE HICIERON LA PATRIA. FICGIONES AGERGA DEL ORIGEN 
"Se nace en cualquier parte. Es el misterio - es el primer misterio inapelable-, pero se ama una tierra como propia y se quiere volver a sus entrañas.

Allí donde partir es imposible, donde permanecer es necesario, donde el barro es más fuerte que el deseo de seguir caminando, donde las manos caen bruscamente y estar

arrodillado es el descanso, donde se mira al cielo con soberbia desesperada y áspera, donde nunca se está del todo solo, donde cualquier umbral es la morada. Donde se quiere arar. Y dar un hijo. Y se quiere morir, está la Patria.»

Julia Prilutzky Farny (1950)

Belgrano reposa sobre una cama de sábanas blancas en un cuarto que parece haber sido oscurecido para permitir el descanso. Conversa con su médico de cabecera, Terranova. Se queja, tose, se adormece, sueña con una batalla, vuelve a hablar con el médico. El general está frustrado. Terranova lo anima: «Hay muchas cosas que hacer, te necesitamos fuerte». Belgrano se rehúsa: «¿Qué más hay que hacer? Yo ya no tengo nada más para hacer». El médico se aparta y va a buscar paños fríos pero cuando vuelve a acercarse a la cama se ha convertido en Belgrano. No en el que yace sino en uno notablemente más joven y saludable. La conversación continúa en el mismo punto en el que había quedado:

«¿Está todo perfecto?, ¿ya hiciste todo lo que querías?», escruta Belgrano, el joven. «No, claro que no, salió todo mal», contesta el convaleciente. El general sano insiste: «Con más razón entonces, tenés que volver, hasta que salga bien. Hasta el final».

El otro no se deja persuadir: «Yo ya estoy en el final. Mirá: sífilis - Le enseña su mano repleta de marcas y se destapa una pierna muy deteriorada y enferma-. Y lo peor está allá afuera: guerra civil, nos estamos matando entre nosotros. Y con la misma bandera, hasta esa idea fue un fracaso». Belgrano del pasado sonríe: «¿Quién te entiende a vos? Antes porque no la quería nadie, ahora porque la quieren todos».

El enfermo parece no tener consuelo: «Fue un fracaso, mirá cómo estamos. No queda nadie. Ni Moreno, ni Castelli, están todos muertos. Ni San Martín. Hasta 
él va a caer en la volteada. Hicimos todo mal. Queríamos cambiar el mundo para dárselo al pueblo y lo que teníamos que cambiar era al pueblo».

Belgrano el sano apela a la fuerza irreversible de los ideales pero el moribundo ya no tiene certezas, ni riqueza, ni amor. El joven se pregunta en voz alta cómo llegará a terminar así. Un soldado irrumpe en la habitación y anuncia: «General, la victoria en Salta es nuestra, el General Tristán lo espera para ofrecerle su rendición incondicional. Ganamos» (Pivotto \& Campanella, 2010, 00:20:28).

La escena transcurre en el minuto veinte de la película Belgrano, dirigida por Sebastián Pivotto, con guion de Juan Pablo Domenech y Marcelo Camaño, producción de Juan José Campanella, coproducción de la Televisión Pública, Canal Encuentro y de la Unidad Bicentenario, auspicio del INCAA - entre otras entidades públicas y privadas - y asesoramiento histórico de Javier Trímboli. El elenco contó con las actuaciones de Pablo Rago como protagonista, Valeria Bertuccelli y Paula Recca en los papeles de las dos amantes del general - María Josefa Ezcurra y María Dolores Helguera, respectivamente-, Pablo Echarri en el rol de José de San Martín, Mariano Torre como Gregorio Aráoz de La Madrid, Pablo Ribba en la interpretación de Manuel Dorrego y Guillermo Pfenning en los zapatos del doctor Terranova.

El argumento se centra en los últimos ochos años de la vida del prócer, la cúspide de su carrera militar, las batallas en Tucumán y en Salta, y luego el ocaso con el avance de su enfermedad. Se trata de una narración construida a partir de los sueños de Belgrano en su lecho de muerte y de las discusiones que entabla con su yo de un pasado no tan remoto, el general exitoso, audaz y esperanzado.

La película se estrenó en 2010 en el Monumento a la Bandera de Rosario y frente a una multitud que alcanzó, aproximadamente, las veinte mil personas. Su difusión continuó luego en distintas ciudades del país mediante el programa Cine para todos, con proyecciones al aire libre por las que circularon miles de espectadores.

Belgrano fue producida a instancias de la conmemoración patria por dos emisoras públicas, una de ellas creada en 2005 , durante el gobierno de Néstor 
Kirchner. ${ }^{74}$ La misma descripción le cabe a Revolución: el cruce de los Andes, de Leandro Ipiña. Este largometraje protagonizado por Rodrigo De la Serna aborda una epopeya de la historia independentista: la travesía por la cordillera, desde Cuyo hacia Chile, del ejército que lideró el general Juan José de San Martín. ${ }^{75}$

Es una obra ambiciosa en términos de producción, rodada en el escenario natural del pueblo de Barreal, en la provincia de San Juan, con un equipo integrado por más de cien técnicos, mil cuatrocientos extras, cientos de mulas y caballos y un gran despliegue de escenografía y vestuario. El pre estreno contó con la presencia de los, por entonces, ministros de Educación y de Trabajo, Alberto Sileoni y Carlos Tomada, del director de Radio y Televisión Argentina, Tristán Bauer, y de la directora del Instituto Nacional de Cine y Artes Audiovisuales, Liliana Mazure. En esa oportunidad, Leandro Ipiña expresó ante la prensa: «es una película de acción, una película épica, y como bien sabemos, un esfuerzo enorme de la Televisión pública y de Canal Encuentro para llevar a cabo esto que, queremos sea, una vuelta del cine épico al cine nacional» (Visión 7, 2011, 00:00:45). ${ }^{76}$

Hablamos, entonces, de dos obras que ofrecen un relato sobre la guerra por la independencia y sobre la fundación de la República. Dos películas que, a su vez, fueron estrenadas en el marco de una celebración particular. Nos referimos ya a la bibliografía que analiza a los aniversarios patrios como ocasiones favorables para que los gobiernos impulsen propuestas conmemorativas dirigidas a disputar y a actualizar

\footnotetext{
${ }^{74}$ Canal Encuentro fue creado por decreto en 2005 y comenzó a transmitir en marzo de 2007. Se trata del primer canal de televisión del Ministerio de Educación de la Nación y es reconocido por la Ley de Educación Nacional 26.206. Su puesta en marcha formó parte de un conjunto de estrategias gubernamentales orientadas a la realización de contenidos audiovisuales, entre las que también pueden destacarse el surgimiento de la Televisión Digital Abierta (TDA) en 2009, la creación de INCAA TV y Pakapaka en 2010, así como de TECtv en 2012 y de DeporTV en 2013, entre otras.

${ }^{75}$ El rodaje de Revolución: el cruce de los Andes (2011) estuvo a cargo de la TV pública, Canal Encuentro y el INCAA, con dirección de Leandro Ipiña, producción de Marina Bacin y Gustavo Villamagna, guion de Ipiña y Andrés Maino, fotografía de Javier Julia, edición de Alejandro Brodersohn, música de Sebastián Escofet sobre una composición de Gustavo Santoalalla y un elenco conformado por Rodrigo De La Serna, Juan Ciancio, León Dogodny, Lautaro Delgado, Victor Carrizo y otros.

76 Visión Siete (5 de abril de 2011). Estrena «Revolución. El Cruce de los Andes». Recuperado de https://www.youtube.com/watch?v=hUvmw6Nk6Qs\&t=45s
} 
las representaciones sobre la identidad nacional y sabemos, también, que el arte suele ocupar un rol protagónico en esa tarea de reconfiguración. Aquí nos proponemos analizar puntualmente de qué modo se desplegó la construcción simbólica de categorías tales como héroe, patria, pueblo, memoria e historia en estas producciones audiovisuales, considerándolas, del mismo modo que en los casos anteriores, como medios de aproximación a las representaciones en torno a lo nacional y a lo identitario legitimadas y promovidas oficialmente por el gobierno en el Estado. Desde una perspectiva de análisis que procurará, una vez más, no desvincular el contenido de su tratamiento formal, nos detendremos en la factura de estas propuestas y buscaremos identificar las elecciones compositivas que se extienden en su poetización.

\section{La fragilidad de los héroes}

Es mayo de 1880. En la pieza de una pensión abatida por el tiempo, en Buenos Aires, un anciano que esconde bajo su saco militar la ropa de calle añeja y una mano derecha que se adivina inútil recibe la visita del periodista Reynoso, que tiene intenciones de entrevistarlo con motivo de la próxima llegada al país de los restos del general San Martín. El viejo es don Manuel Esteban de Corvalán, quien con quince años, por saber leer y escribir, se convirtió en el secretario personal del libertador y en uno de los hombres que protagonizaron la hazaña en la cordillera. 


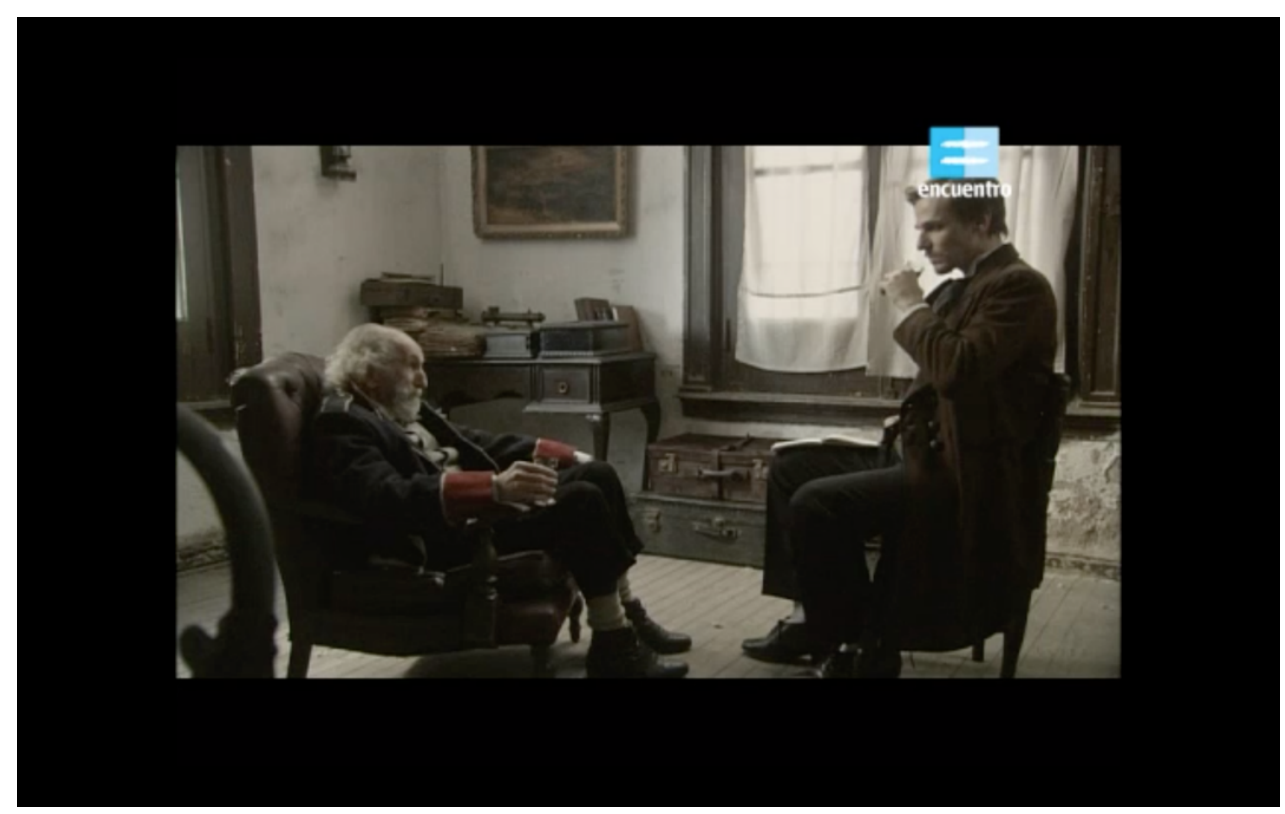

Fotograma de Revolución, el cruce de los Andes, de Leandro Ipiña

La trama de Revolución, el cruce de los Andes se teje a partir de los recuerdos de Corvalán en diálogo con el periodista. Este último $-y$ con él, probablemente, muchos espectadores-verá sutilmente profanada su figuración del líder revolucionario a medida que avanza el relato. La semblanza de un San Martín corpulento, vigoroso, de mirada penetrante y perspicacia fuera de lo común que esboza Reynoso en los primeros minutos del largometraje es contrastada con la reseña que hilvana Corvalán al hurgar en su memoria. Vemos allí a un hombre fuerte pero perturbado, de mal carácter, profundamente desconfiado, que sufre por tener que dejar su hogar y que esconde su enfermedad para no mostrar debilidad. Incluso los guionistas se toman la licencia de poner en cuestión el porte físico del héroe, aludiendo, mediante la descripción de Corvalán, a su mediana estatura y a su nariz prominente, un atributo indisimulable del actor protagónico, De la Serna, quien para preparar el personaje tuvo que aprender equitación, esgrima y estudiar el acento español (Clarín, 2011). ${ }^{77}$

\footnotetext{
77 Clarín (01 de abril de 2011). Rodrigo de la Serna: «San Martín fue muy manipulado». Recuperado de https://www.clarin.com/cine/titulo O HkE08Eaw7e.html
} 
Gustavo Aprea (2012) sostiene que a mediados de la década del noventa se produjo un quiebre dentro de la filmografía histórica argentina que implicó mutaciones en las modalidades de narración del pasado. En lo que el autor distingue como un nuevo régimen de historicidad ${ }^{78}$ la reconstrucción de la complejidad en la vida privada de las figuras históricas se erige como condición para la verosimilitud, al tiempo que esa misma dramatización de las biografías pone en tensión el rol de estos personajes, antes incuestionable, en la conformación de entidades colectivas como el pueblo o la nación. En ese nuevo marco, según Aprea, las disputas del presente son presentadas en una línea de continuidad con un pasado conflictivo, lo cual también tiene sus implicancias programáticas: "Ya no hay un destino prefijado sino un camino lleno de dudas y signado por fracasos. La nueva heroicidad se construye sobre personajes que deben superponerse a sus propios errores y en muchos casos tienen dudas sobre el resultado final de su accionar» (p.10).

En los casos analizados, las características transversales dispuestas por ese nuevo régimen de historicidad cinematográfico sobre el que nos advierte Aprea parecen conjugarse con una significación específica de la figura del héroe activada en la etapa kirchnerista, que tal vez haya encontrado su expresión más inmediata en la imagen de Néstor Kirchner luciendo un corte profundo en la frente a causa de haber chocado con la cámara de un fotógrafo mientras se acercaba a saludar a los manifestantes en Plaza de Mayo, minutos después de la jura para desempeñar su rol como principal mandatario de la República, con el bastón y la banda presidenciales todavía a cuestas.

\footnotetext{
${ }^{78} \mathrm{El}$ autor define al régimen de historicidad como «la manera en que la sociedad se planta frente a su pasado, se proyecta hacia un futuro y define su situación presente» (Aprea, 2012, p.1) y argumenta que en la producción cinematográfica que aborda el pasado nacional en la actualidad es posible distinguir características comunes que diferencian a las nuevas propuestas de las de otras etapas.
} 


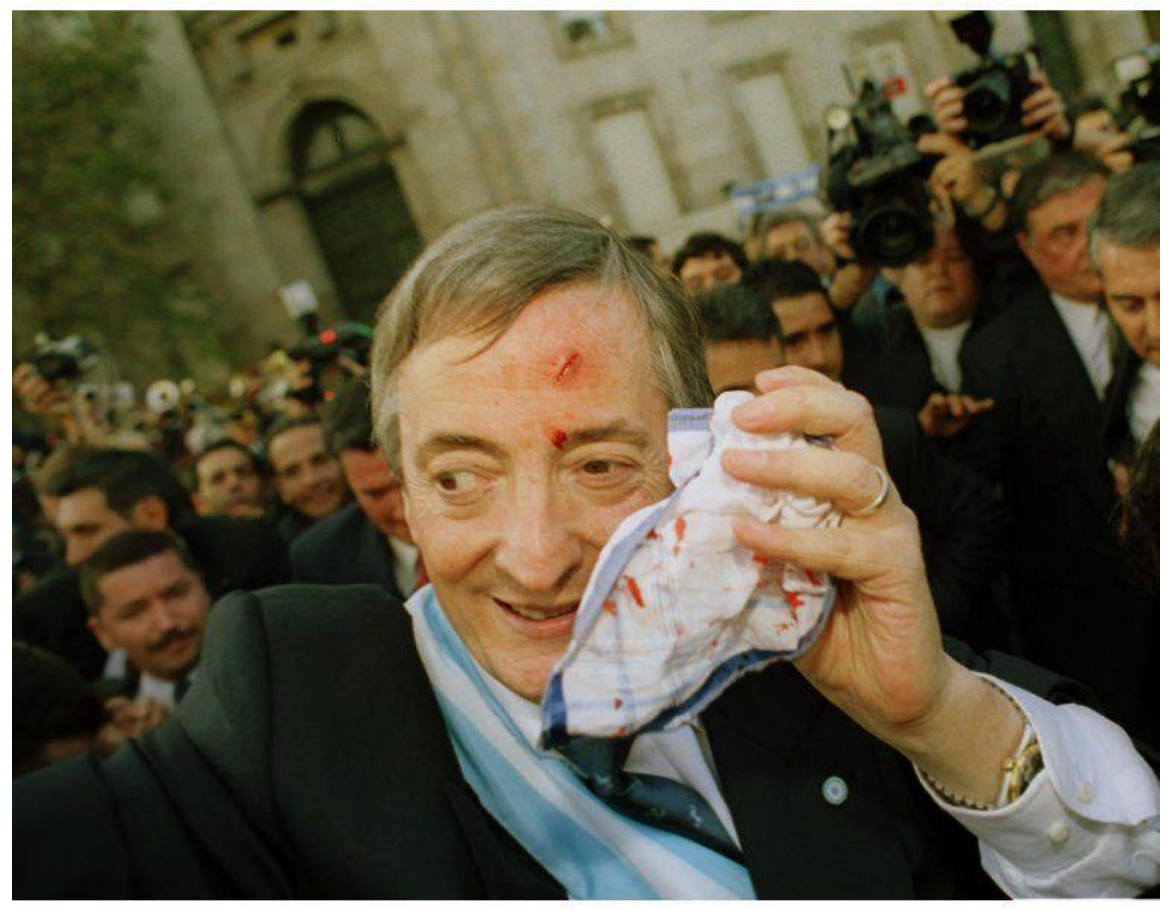

Néstor Kirchner el día de su asunción como presidente de la Argentina

El hombre se vuelve héroe al mezclarse en el conjunto, su imagen es la del Eternauta, el salvador colectivo. El heroísmo se nutre de la torpeza, deviene desaliñado, gana bravura al perder el bronce, puede encarnar en una mujer. El héroe muere en batalla pero quien lo embiste, finalmente, es su propio corazón.

Si bien los films que estamos indagando comparten elementos característicos del relato épico - los protagonistas representan valores fundamentales para el bien común que deben ser defendidos mediante la lucha contra los enemigos, quienes, de un modo u otro, personifican el mal que debe ser derrotado- ambas propuestas dan cuenta de una búsqueda que escapa a los estereotipos clásicos en lo que respecta a la semblanza del líder.

En Belgrano, la acentuación de la fragilidad del prócer se vuelve un elemento estructurador. El énfasis está puesto en una intromisión del espectador en la 
intimidad de este personaje cuyas preocupaciones sociales adquieren un espesor equiparable a los lamentos personales: la soledad, el desamor, la paternidad frustrada, etcétera.

En Revolución, la épica clásica que podemos identificar en una escena como la de la arenga previa a la batalla de Chacabuco en la que, al mejor estilo William Wallace en Corazón valiente (1995), ${ }^{79}$ el San Martín de De la Serna insta a los soldados de su tropa a dejar la vida en el campo de batalla y a ser libres, pues lo demás no importa nada, es puesta en tensión por tramos como aquél en el que protagonista se disculpa con su mujer por haber estado irascible y se muestra temeroso de no poder ver crecer a su hija.

De todos modos, tal vez en este largometraje el personaje que expresa con mayor claridad el perfil anti heroico del que hablamos es el de Corvalán, el soldado olvidado, que adeuda la renta de su habitación en una pensión de mala muerte y añora, desde la nostalgia de una vejez solitaria, el tiempo de la revolución.

\section{Fronteras}

«¿Cómo definiría al padre de la patria?» le pregunta Reynoso a Corvalán. «¿Qué es para usted la patria?» devuelve el anciano. El periodista se incomoda pero empieza a esbozar una respuesta: «Bueno... la patria es el... es el territorio». El viejo lo interrumpe con impaciencia: «¿Padre de qué patria?, ¿de la que ustedes llaman la Argentina?, ¿de lo que fue el reino de Chile?, ¿de Perú?, ¿de todas juntas?»

Diálogo de Revolución, el cruce de los Andes (Ipiña, Bacin \& Villamagna, 2011, 00:21:17).

En la escena inaugural de Belgrano, mientras los créditos se suceden unos a otros, vemos, en primer lugar, tres picos de montañas sobre un cielo algo nublado y escuchamos una melodía de notas largas desplegada por lo que podemos intuir como

${ }^{79}$ Corazón Valiente (o Braveheart, en su nombre original) es una película dirigida y protagonizada por Mel Gibson, que narra la historia de William Wallace, un líder escocés que lucha en la primera guerra de independencia de Escocia. 
una orquesta sobre el acompañamiento de un piano. ${ }^{80}$ La música es interferida por voces lejanas de hombres que parecen encontrarse en un campo de batalla. Se escuchan también algunos cañonazos, espadas que chocan entre sí, relinchos de caballos. La melodía orquestada reproduce lo más estereotipado de la música occidental del siglo XIX y aparece en una suerte de simbiosis con el sono. Esa resonancia amplificada de las cuerdas remeda uno de los recursos más fatigados cuando se trata de darle un marco sonoro a los sueños. Por momentos los gritos no funcionan como una referencia externa a este registro extra diegético sino como parte de ese mismo clima de pretendida alucinación.

De pronto oímos con mayor claridad y en primer plano un inconfundible «viva la patria». Aparece en escena el general -Pablo Rago-, tendido en la cama, sudoroso, sumido en un sueño. Sujeta con fuerza su frazada y tironea de ella. Esa imagen se intercala con otra en la que muchas manos de mujeres cosen entre sí dos grandes telas, una celeste y una blanca. Las dos escenas comienzan a alternarse con mayor frecuencia y los planos se vuelven más puntuales, hasta que en determinado momento no llegamos a distinguir si lo que sujeta Belgrano con sus manos es la frazada o la tela que está siendo zurcida. La música va creciendo en tensión y volvemos a escuchar el vitoreo de varios hombres que gritan nuevamente «viva la patria» mientras la bandera, ya terminada, flamea en el aire. Belgrano tose, todavía dormido, es evidente que su sueño se ha convertido en pesadilla. Un fuego crepita en la chimenea de la habitación pero las imágenes se funden y de pronto las llamas arden sobre la bandera. Luego se produce un cambio súbito de escena que da lugar al comienzo de la trama donde la imagen sonora y la visual reflejan una situación de época. Más allá de la disparidad de estilos se trata de música del mismo período. Mientras el romanticismo alemán pretendía una música puramente abstracta la incipiente urbanización criolla buscaba en huaynos una identidad aún no singularizada (Pivotto \& Campanella, 2010, 00:00:21).

\footnotetext{
${ }^{80}$ El creador de la banda sonora de Belgrano es Emilio Kauderer, un compositor con larga trayectoria en el rubro, cuya impronta puede escucharse en distintas obras de Juan José Campanella como $\mathrm{El}$ secreto de sus ojos, El mismo amor la misma lluvia o la serie televisiva Vientos de agua.
} 

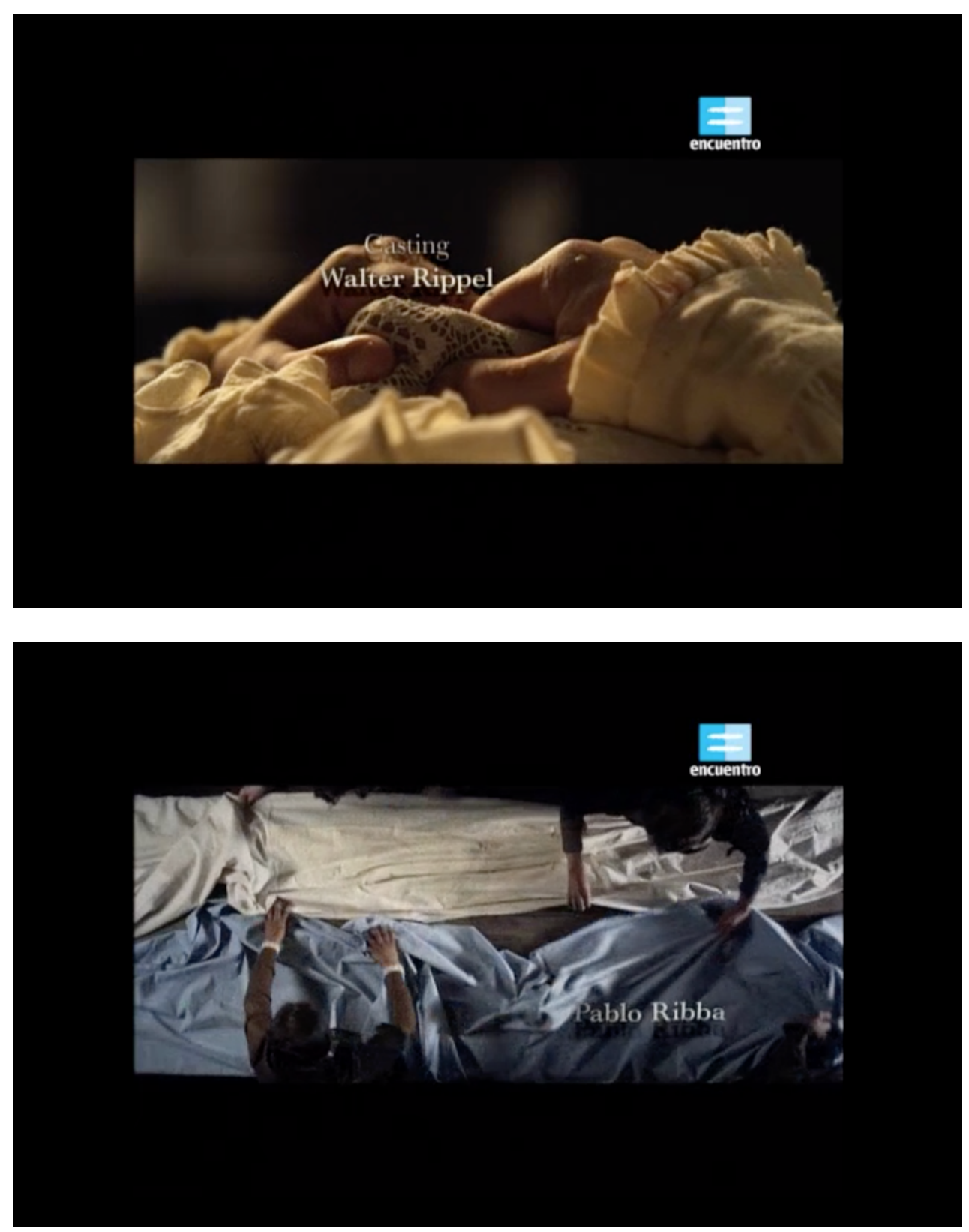

Fotogramas de la presentación de Belgrano, de Sebastián Pivotto

Ese prólogo condensa un conjunto de señales mediante las cuales podemos acceder a rasgos que surcan la totalidad de la obra, muchos de los cuales valen también para el análisis de Revolución: el cruce de los Andes. En estas piezas, la idea de nación aparece fundida en la de patria la cual, en paralelo, encuentra su cauce en una lucha cuyo principal protagonista es el pueblo. Se trata de un arquetipo de 
contornos difusos, que lejos de aparecer como un constructo acabado, impoluto e imperturbable se nos presenta frágil y abatible: la patria es un trozo de tela suave que ante la menor distracción puede ser devorada por el fuego enemigo.

En su aporte a una investigación más amplia sobre la construcción de otredades en los relatos audiovisuales argentinos, Daniel Carmelo Scarcella (2013) analiza cómo estos dos largometrajes toman identidades que habían sido consideradas por la historiografía mitrista como marginales y periféricas, para ubicarlas en un lugar central del guion. El autor argumenta:

En este discurso se ha presentado, en el origen de la nación, a los ricos como oponentes, sean del clero, comerciantes, o funcionarios políticos. A los negros ocupando posiciones jerárquicas, a los indios como aquellos que deberían ocupar el poder, y uno de los principales beneficiarios de la independencia. Esas representaciones son opuestas al pensamiento mitrista: el indio como lastre, y el criollo de élite como el actor legitimado para gobernar (p.12).

Podríamos añadir a esa enumeración a las mujeres, como aquellas que enhebran los hilos de la historia, en su rol de trabajadoras y, también, como las encargadas de confrontar a los líderes y de poner en cuestión su heroísmo en el plano de la intimidad. Suscribimos a Scarcella en su descripción de un pueblo que no es representado en las ropas de un sujeto homogéneo y pasivo al que se lo beneficia con la libertad; el pueblo representa un colectivo heterogéneo, apasionado, sacrificado, persistente, formado por actores diversos que forjan su propio destino y que, haciéndolo, dotan de forma y contenido a la nación.

Si quisiéramos forzar el hallazgo de una continuidad en la articulación simbólica del kirchnerismo argumentaríamos que el diseño de una imagen de pueblo esbozado en estas obras - que también identificamos en otras producciones artísticas de ese mismo lapso, como el desfile performático de los festejos de Bicentenario o los capítulos de La asombrosa excursión de Zamba-, encontró, unos años después, su síntesis enunciativa en la emblemática máxima formulada por Cristina Fernández de Kirchner en 2013, "la patria es el otro», y en el marco de sentido perfilado por la presidenta en torno a ella: 
[Estamos aquí para] decirles a todos y a cada uno de los argentinos, a lo largo de estos 200 años de historia, que han luchado por la independencia, que han luchado por su patria, que han luchado por sus ideales, por sus convicciones, porque luchar por la patria también es luchar por el otro, por el prójimo, que jamás volverán a ser olvidados [...] si no se quiere al pueblo, si no se quiere al prójimo, es imposible querer a la patria. La patria es el otro, la patria es el prójimo (Casa Rosada, 2013)..$^{81}$

La Patria es el otro, la patria es el otro. Es el que todavía no ha podido conseguir trabajo, o el que consiguiéndolo no está registrado. La patria es el que todavía tiene, y lucha, y trabaja para tener su casa propia. El otro es ese joven que tal vez no puede estudiar todavía porque tiene que trabajar para ayudar al hogar. El otro también es el que sufre adicciones y que tenemos que ayudarlo a ese hermano, rescatarlo entre todos para combatir los flagelos modernos que tiene nuestra sociedad. La patria es estas mujeres que han luchado 35 años pidiendo justicia [...] (Visión 7, 2013, 00:42:32). ${ }^{82}$

En la escena final de Revolución: el cruce de los Andes, Reynoso intenta sacarle una fotografía al viejo Corvalán para ilustrar la nota en el periódico. Están en una suerte de patio interno de la pensión, por el que circulan vecinos y vecinas que llevan adelante distintas tareas: una mujer lava la ropa, otras dos extienden algo sobre una mesa, los niños juegan y un hombre con vestimenta de trabajo se esfuerza por evitar que rompan algo. El periodista ha ubicado una silla frente a la cámara con la intención de obtener un retrato del soldado, pero Corvalán es, ante todo, un abuelo. «Vengan todos", dice, y los vecinos comienzan a rodearlo. Reynoso, resignado, les pide que se junten, son demasiados para entrar en la foto. Pero entran. La nota en el periódico llevará como título "Los que hicieron la patria» (Ipiña, Bacin \& Villamagna, 2010, 01:27:00).

\footnotetext{
${ }^{81}$ Casa Rosada (2013). 310 aniversario del inicio de la Guerra de Malvinas: discurso de la Presidenta de la Nación. Recuperado de https://www.casarosada.gob.ar/informacion/archivo/26411-310aniversario-del-inicio-de-la-guerra-de-malvinas-discurso-de-la-presidenta-de-la-nacion

82 Visión Siete (25 de mayo 2013). Visión siete: Discurso de Cristina Fernández de Kirchner [Archivo de video]. Recuperado de https://www.youtube.com/watch?v=JutKZ9mAeiQ
} 


\section{El sueño y el olvido}

«Si el sueño fuera (como dicen) una

tregua, un puro reposo de la mente, ¿por qué, si te despiertan bruscamente, sientes que te han robado una fortuna? ¿Por qué es tan triste madrugar? La hora

nos despoja de un don inconcebible, tan íntimo que solo es traducible en un sopor que la vigilia dora de sueños, que bien pueden ser reflejos truncos de los tesoros de la sombra, de un orbe intemporal que no se nombra y que el día deforma en sus espejos. ¿Quién serás esta noche en el oscuro sueño, del otro lado de su muro?.»

Jorge Luis Borges (1964)

$\mathrm{Ha}$ sido dicho en otros escritos con claridad: en las sociedades contemporáneas el lenguaje audiovisual participa en la provisión de imaginarios y formas de identificación colectiva y es un elemento a escudriñar a la hora de comprender la textura de esas comunidades imaginadas que son las naciones (Aprea, 2014; Russo, 2017). Por otra parte, como sostiene Paola Margulis (2017) cuando cita a Michael Chanan, todo film es un documento de sí mismo y está inscripto en sus propias condiciones de producción. En este caso debemos añadir que se trata de largometrajes creados bajo la tutela del Estado con el objetivo de ser estrenados en el marco de una celebración particular, que ofrecen un relato acerca del origen de la República disputando, en mayor o menor medida, ciertas construcciones de sentido con la versión historiográfica clásica, que se elaboraron estrategias para garantizar su difusión a lo largo y a lo ancho del país y que se promovió su uso como recurso pedagógico en las escuelas. ${ }^{83}$

Estas cualidades despertaron, como es esperable, simpatías y objeciones. Las réplicas, aunque menos cuantiosas que los elogios, se extendieron en un espectro

${ }^{83}$ Ver: Di Meglio (2010). 
que abarcó desde reparos frente a la calidad actoral de los elencos, pasando por impugnaciones a la obscenidad oficialista de las películas, a su realismo comercial, a su alimentación del miedo como arma de persuasión y a su falta de sustancia crítica, hasta llegar a la ausencia de rigor histórico del guion (Batlle, 2011; Tal, 2013; Rossi Delaney, 2015).

Nos interesa detenernos en este último señalamiento porque consideramos que es allí donde tal vez se vislumbre la decisión compositiva más interesante que nos ofrecen estos largometrajes.

Hablamos, claro está, de ficciones. Pero, además, en estas ficciones la narración se construye a partir del sueño y de la memoria individual. En Belgrano, es el propio protagonista quien fabrica el relato a partir de la ensoñación en la que lo sumerge su enfermedad, que lo lleva a entablar un diálogo consigo mismo. Y en ese ida y vuelta por momentos se desdibuja quién imagina a quién: ¿̇es el pasado el que interroga al futuro o el presente el que intenta reconducir ese pasado para salvarse?

De un modo similar, en Revolución. El cruce de los Andes el viaje hacia la cordillera nos es habilitado por los recuerdos del entrevistado, conocemos a San Martín a partir de la reconstrucción de Corvalán y nuestro acercamiento a los días de la revolución está mediado por su memoria que, vale decir, es la memoria de un anciano.

Pero, ¿qué es el sueño?, ¿qué es la memoria? Digamos algo acerca de estos asuntos. En el capítulo anterior nos hemos referido brevemente a la dimensión colectiva de la memoria. Según Enzo Traverso, ocuparse de este concepto entraña atender también a problemas referidos a la subjetividad, a la cientificidad de la historia, al lugar conferido a los testimonios como fuentes y a la posibilidad de reponer con objetividad un pasado que ha sido vivido intensamente (Madonesi, 2008).

¿Cómo se enlaza la memoria con el olvido?. Los recuerdos operan de manera destructiva imponiéndose como algo involuntario, no deseado, que nos captura sin que sepamos por qué, como la conciencia reprimida en el laberinto del inconsciente 
de quien ha pretendido olvidar sin comprender. Lo que permite la memoria es justamente el entramado que se impone a esa desconexión. Walter Benjamin (1982 [1940]) lo explicó muy bien y existen innumerables análisis sobre sus trabajos, puntualmente sobre su breve tesis acerca del Angelus Novus, de Paul Klee, por lo que haremos apenas un comentario, casi una nota de color. Creemos que, cuando él se refiere a aquél ángel que intenta mirar hacia el pasado, despertar a los muertos, pero esto le es impedido por un huracán, una tormenta que lo empuja sin piedad hacia el futuro, esas ruinas que fulguran en los intersticios de la homogeneidad temporal moderna no son compatibles con una visión posmoderna y fragmentaria. Se podría hablar, por el contrario, de una totalidad interrumpida que necesariamente implica nexos, conectores, vínculos entre fulgor y fulgor, lazos que, en las ruinas, nos permitan volver relativo el transcurso temporal y establecer en su flujo ciertas continuidades. Es decir, la memoria.

En cuanto a los sueños, sin pretender escarbar en terrenos teóricos que nos resultan desconocidos, aceptaremos, con Freud (1900), que los sueños habilitan una vía privilegiada de acceso al inconsciente, expresan el cumplimiento disfrazado de los deseos reprimidos, implican la existencia de dos planos yuxtapuestos y simultáneos que difieren en que uno pugna por salir mientras que el otro trata de impedirlo. En el sueño, el inconsciente deforma el mundo real para engañar al consciente mediante estrategias como la condensación y el desplazamiento. Estos descubrimientos tan decisivos para el pensamiento contemporáneo tuvieron, claro está, su impacto en el arte. Hemingway, Borges, Juan Carlos Onetti, César Aira, Walsh, Piglia, el surrealismo, Debussy, Silvio Rodríguez, por mencionar solo algunos nombres. En los sueños y en el arte, algo está en el lugar de otra cosa, como en la instalación During sleep, de la artista japonesa Chiharu Shiota, en la cual los hilos de una inmensa e impenetrable telaraña recubren por completo la habitación en la que apenas se descifra una cama vacía. 


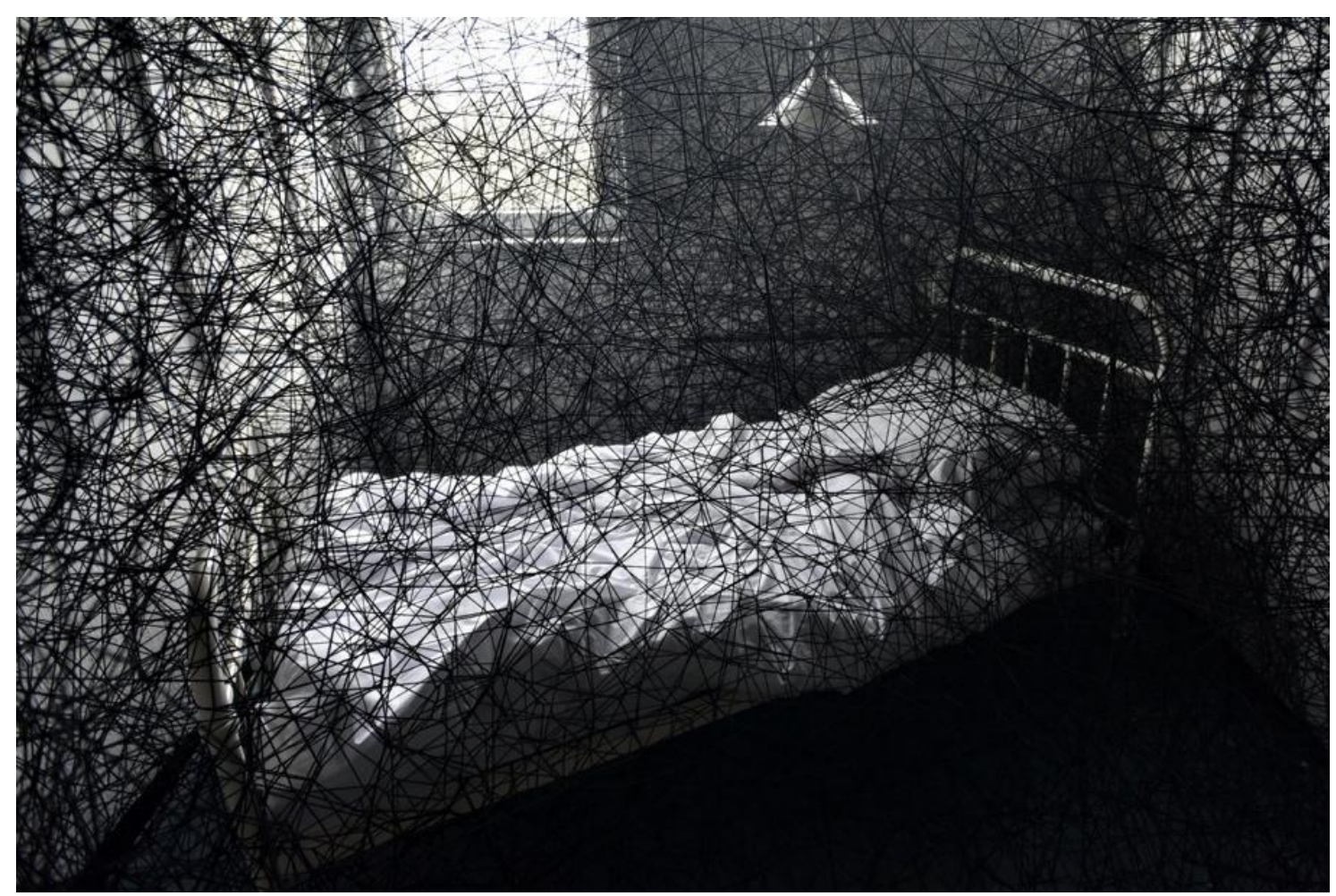

During sleep, de Chiharu Shiota (2017)

Que no se nos malinterprete. Esta acentuación de la ambigüedad usada como recurso narrativo no implica que los creadores hayan escatimado esfuerzos en lo que respecta a la proporción de un piso de realismo y verosimilitud. Basta recorrer la entrevista realizada por el titular de la cátedra Fotografía Cinematográfica y TVI de la Universidad de Córdoba a Javier Jouliá (Cottet, Gómez \& laccarino, 2012), director de fotografía y cámara en Revolución, y sus revelaciones acerca del estudio minucioso que realizaron tanto él como Leandro Ipiña en torno a las primeras fotografías a color, con el objetivo de lograr una imagen degradada mediante filtros, subrevelados y otros procesos, para que la película se viera como si hubiera sido filmada a comienzos del siglo XIX, cuando el cine aún no existía. Al respecto, el propio Ipiña comenta:

Las películas comienzan siempre con una imagen. Esa imagen está, desde su concepción, teñida por una idea. Podríamos decir premoldeada. En el caso de "Revolución», la imagen de San Martín y su ejército estaba detrás de una nebulosa de difícil acceso. El paso del tiempo, las sucesivas manipulaciones, la dificultad de dar con un retrato fiel llevaban a la reconstrucción casi artesanal de una imagen derruida. Una de las características más notorias del Ejército de los 
Andes (que lo diferenciaba de los demás ejércitos) era que contaban con uniformes prácticamente nuevos, de colores vívidos. ¿Cómo lograr entonces una imagen desgastada, y a la vez salvar los uniformes? Las fotos y negativos coloreados, los experimentos en color de los primeros fotógrafos o el primer Technicolor funcionaron como base para acercarnos a ese tratamiento del color que buscábamos [...]. La imperfección de la imagen fue la premisa que seguimos con Javier Juliá (ADF) desde el primer momento. Tratamos siempre de evitar la supuesta «belleza» en la que caen las películas de época. Sabíamos que el laconismo tanto en la fotografía como en el arte, el vestuario, y también las actuaciones iban a darle el tinte de realidad que buscábamos. Realidad tan difícil de conseguir cuando el retrato ha sido tantas veces tergiversado y manipulado de manera grosera por la historiografía clásica (Cottet, Gómez \& laccarino, 2012).

En una línea similar, resulta sugerente el comentario que hacen Sebastián Pivotto y Fernando Alcande - asistente de dirección en Belgrano-, con relación al empeño puesto para filmar el izamiento de la bandera en un día de rodaje sin viento: la faena involucró el ingreso de un ventilador cuyo aporte resultó escaso, de una turbina demasiado potente y de una serie de intentos fallidos con tanzas hasta que, finalmente, un golpe de suerte trajo, en la última hora de luz, la tan ansiada brisa, sutil pero perfecta para lograr un movimiento que se percibiera real (TV Pública Digital, 2011).

Entonces, ambas propuestas desearon consolidar relatos creíbles acerca del pasado. Pero, al mismo tiempo, las dos plantaron en su núcleo compositivo la semilla de la ambigüedad que diluye cualquier pretensión de objetividad histórica en el carácter inapelable de las interpretaciones múltiples y siempre abiertas.

No diremos algo novedoso: cada intento de retornar al pasado es en sí mismo una oportunidad para descifrar aquello que ha permanecido velado y reanudar su marcha en el ahora. A su vez, las obras de ficción, que no son ni ciertas ni falsas sino que se dirimen en esa tensión, son consideradas datos de la historia. En ese sentido, las producciones aquí reseñadas participan en la disposición de lo imaginable y de lo pensable en nuestra nación (Russo, 2017). Son, finalmente, posibles configuraciones de tiempo y espacio que también cobijan en sus entrañas memorias e historias cuyo desentrañamiento le corresponderá a quienes observen, desde un huracán que aún desconocemos, las ruinas de este tiempo. 
CONCLUSIONES 
En estas páginas hemos intentado ofrecer una reflexión sobre los modos en que el arte configura imágenes identitarias y símbolos que diseñan una idea de nación. El acercamiento a las producciones audiovisuales y performáticas impulsadas por el Estado argentino durante el primer mandato de Cristina Fernández -en el marco de la conmemoración del Bicentenario de la Revolución de Mayo- nos permitió abordar este asunto con una metodología que privilegió la profundidad analítica frente a las posibilidades de generalización.

Para comprender el contexto de producción de los materiales reunidos en la muestra se indagó de un modo más abarcativo en la propuesta artística y cultural de los gobiernos de Néstor Kirchner y de Cristina Fernández y se rastrearon allí posibles enlaces con las características reveladas en ese mismo plano por los gobiernos peronistas, a partir de dos premisas. La primera: ambos modelos plantearon una puja en el universo de las imágenes visuales, sonoras y audiovisuales que funcionó en síntesis dialéctica con la disputa librada a nivel político y económico. La segunda: en los dos casos, esa estrategia fue objeto de réplicas que se montaron en el supuesto esencialismo nacionalista y estereotipado que habría caracterizado la factura artística de estos gobiernos.

Con base en esas presunciones, nos aproximamos a este asunto desde una mirada que procuró despojarse de asociaciones unívocas para dar lugar al reconocimiento de fluctuaciones y de zonas menos exploradas en el lazo entre el kirchnerismo y el vasto universo del arte.

En el estudio de la serie animada La asombrosa excursión de Zamba, de los festejos del Bicentenario y de los largometrajes Belgrano y Revolución, el cruce de los Andes rastreamos aquellos aspectos que atestiguaran formalizaciones referidas al concepto de nación, identificando los contenidos históricos, políticos y culturales desplegados en esas propuestas para después reponer las decisiones compositivas impresas en su poetización.

¿Cómo se desplegó la construcción simbólica de la nación en este conjunto de propuestas audiovisuales y performáticas desarrolladas en el marco de la segunda 
etapa del período kirchnerista? Por un lado, a modo de primera conclusión, diremos que es posible identificar una serie de características comunes en todas las producciones a la hora de figurar la idea que nos ocupa: la nación allí esbozada se consolida en el reconocimiento de la heterogeneidad, es forjada por mujeres y hombres que se equivocan, incluye a actores que habían sido en otros períodos desplazados de la historia oficial, resulta por momentos indivisible de categorías como las de patria, pueblo y territorio, encuentra su norte en el proyecto de unidad latinoamericana, levanta como banderas la lucha por el ejercicio pleno de la soberanía económica y cultural, el respeto de los derechos humanos y la búsqueda de justicia social, se vuelve vigorosa en el heroísmo colectivo y encierra en sí misma la fortaleza y la fragilidad de una bailarina que pende de un hilo pero es capaz de correr en el aire.

Por otro lado, los diferentes dispositivos estudiados también comparten como cualidad el haber apelado en sus formas a apropiaciones colectivas de imágenes sonoras y visuales que pueden resultar familiares y fácilmente identificables para un número grande de personas sin resignar, en la mayor parte de los casos, la búsqueda de desplazamientos y de operaciones metafóricas. Cuando Fito Páez estampó el sello de su voz rota y de sus consonantes marcadas en el himno interpretado junto a un grupo de artistas en el cierre de uno de los recitales del Bicentenario, cuando Pivotto dispuso que la trama de su película se estructure a partir del debate entablado entre un Belgrano moribundo y su yo del pasado, cuando el artista que dibujó a Zamba ilustró una botella como insignia en el casco de Galtieri o cuando el guionista y el musicalizador determinaron que Bolívar -cuyo carácter y omnipresencia trascendieron como algo más que un comentario de prensa amarilla- ingresara a la escena como si fuese Lady Gaga entrando a la entrega de los Premios Oscar, tomaron decisiones formales que implicaron e implican para el espectador una desautomatización.

Detallamos cómo los cuadros presentados en el Desfile del Bicentenario proponían a los concurrentes mirar hacia arriba y no hacia el frente, en una disposición espacial difusa, móvil, efímera, tal vez cercana a la contemporaneidad 
fragmentaria pero definitivamente no a la teleología propia del arte clásico. Hemos visto también la doble direccionalidad que adquiere el tiempo en los viajes de Zamba y cómo la música, el sono y la palabra son utilizadas en algunos tramos de manera novedosa para el género, fundiendo los tres registros en una suerte de poema más cercano al dadaísmo y a las vanguardias que al «Evita me ama» de los libros escolares. Nos detuvimos en recuperar el modo en que artistas visuales, músicos, escritores, actrices y directores explican su modo de componer o despliegan sus producciones por fuera de las intenciones políticas, como se percibe en la preocupación de Ipiña y Jouliá por lograr una imagen degradada mediante el tratamiento del color para generar la idea de pasado en Revolución. El cruce de los Andes, en la profundidad de Piglia al hablar de Borges o en las clases de filosofía de Feinmann, trabajadas en un espacio ficcional sin contornos, donde el protagonista se convierte en un pequeño sujeto suspendido en la nada mientras habla con la misma pasión de Heidegger o de Moreno, envuelto en animaciones y elementos gráficos absolutamente comprimidos y sintéticos. Se imprime allí una dinámica que diluye el tema, lo convierte en trama y corrompe las lecturas lineales.

No se intenta sostener en este punto que el kirchnerismo haya adquirido en su proyecto estético ribetes surrealistas o que las obras promovidas para narrar la historia nacional den cuenta de esmeros por alcanzar la neutralidad valorativa o la objetividad imperturbable de un pensamiento desligado de posicionamientos ideológicos. Lo que decimos es que aún con las propiedades de la pugna entre realismo y abstracción a cuestas, en las obras observadas puede reconocerse cierta huida del esencialismo que le ha sido endilgado como un lastre estigmatizante al peronismo en términos generales. La identidad, casi siempre asociada a lo estanco, parece haber brotado aquí de lo mutante, plasmando así una idea que Adolfo Colombres ([1987]2007) esboza en su ya clásico libro sobre el tema: la verdadera cultura y el arte popular residen en la posibilidad de que los sectores que componen ese colectivo alcancen las libertades de las formas que los representen.

Aquí, entonces, una segunda conclusión: aún cuando dentro del mismo espacio político haya existido cierto fundamentalismo en el lenguaje y en el modo de 
afrontar la disputa con los medios hegemónicos que sirvió de excusa a la oposición para objetar las propuestas estudiadas, en ellas el planteo artístico dista de poder encuadrarse en el mote de realismo nacionalista estereotipado y, con sus más y sus menos, introduce zonas de desvío, fisuras e incluso contradicciones acordes a las pujas discursivas detectables en el plano de la estructura política. Las imágenes creadas por los gobiernos de Néstor Kirchner y Cristina Fernández fueron pensadas para públicos diversos y no para un único actor social. Si el primer peronismo resultó revolucionario en el sentido de los derechos adquiridos y en términos de los sujetos sociales que le otorgaron identidad, el kirchnerismo, acaso con logros menos abrumadores en términos económicos, intentó incorporar a otros sujetos sociales con sus intereses particulares (los organismos de Derechos Humanos, los jóvenes, los movimientos sociales, los feminismos y colectivos LGTBI, etcétera) y eso se expresó en propuestas culturales y artísticas con una mayor apertura y ambigüedad.

Un comentario más, a riesgo de reiterarnos. Hemos dicho que la batalla simbólica sostenida por estos gobiernos implicó el fomento del papel del Estado como emisor y productor artístico. En ese sentido, evaluamos las propuestas investigadas como andamios que nos acercaron a las representaciones legitimadas oficialmente en torno a la nación y, en línea con esto, resultó clave atender a los anhelos de alcanzar masividad como sello en la factura de cada uno de los materiales.

Recordemos: la organización de los festejos bicentenarios dependió de un equipo integrado directamente por la presidenta y por un conjunto de colaboradores cercanos a la gestión, su realización involucró a alrededor de cinco mil artistas y trabajadores de la cultura y la celebración fue presenciada por espectadores que se computaron en millones. Por su parte, los dos largometrajes y la animación de Pakapaka fueron creados en colaboración con el Ministerio de Educación y contaron con la producción y la emisión de dos canales públicos de la Argentina. Estos audiovisuales se distribuyeron en todas las provincias del país, fueron proyectados en las aulas y en las plazas de una enorme cantidad de distritos y se escribieron materiales pedagógicos para acompañar la interpretación de sus contenidos. 
Sin embargo, lo sabemos, las voluntades no se concretan de manera mecánica. Ni el Estado constituye una totalidad homogénea de Ushuaia a Humahuaca, ni sus propuestas impactan en sujetos unívocos y universales desde los pueblos rurales cuyas escuelas a veces tienen una única alumna hasta la realidad en sí misma dispar de las grandes urbes que se revela con crudeza en los días en que escribimos estos párrafos finales, en medio del aislamiento preventivo frente a la pandemia de COVID 19.

En un sentido similar, la construcción de la memoria colectiva y de los símbolos que dan carnadura a esa comunidad imaginada que llamamos nación tampoco puede ser concebida como un proceso universal, unilateral y abstracto. En su elaboración, las omisiones, las negociaciones o los acentos responden, muchas veces, a reservorios individuales o a interpretaciones permeadas por grupos de pertenencia de carácter más segmentado. Debemos asumir, entonces, que estas propuestas han discurrido por senderos infranqueables, que probablemente han sido objeto de lecturas propensas a pendular entre el interés, la literalidad y la apatía, y que su destino y sus impactos exceden los objetivos y las posibilidades de esta investigación.

Con todo, las expectativas sobre ese devenir sí forman parte de los elementos que nos conciernen y allí la noción de soberanía cultural y artística se alza como una clave de lectura para comprender el pulso programático en los casos analizados. La significativa inversión en infraestructura - hemos reparado en la inauguración de museos, centros culturales, muestras interdisciplinarias de gran envergadura como Tecnópolis, etcétera-, el fomento de las industrias culturales y artísticas, la actualización de los contenidos y de las propuestas de enseñanza de las artes en los niveles obligatorios, la compra de libros y su distribución gratuita, la construcción y el análisis de datos sobre el área a nivel federal, la incidencia sobre la política de medios vigente, la creación de canales y contenidos, la iniciativa para regular derechos laborales de las y los trabajadores del arte y la reestructuración compleja de los bordes entre política, arte y cultura a partir del entramado con determinados colectivos y actores externos al gobierno, permiten pensar que en el kirchnerismo, 
como en el peronismo, hubo de todo, pero lo que sin dudas hubo fue más producción que en otros momentos de la historia, en los que las manifestaciones además de elitistas fueron restringidas.

Hablamos, por lo tanto, de la definición de un tipo de soberanía en el plano del arte y de la cultura que, como se ha dicho, logró integrar categorías históricamente presentadas como antagónicas -la abstracción poética, el desplazamiento, la exploración metafórica; la identidad, lo cercano, lo regional, lo multitudinario - con una matriz latinoamericana acorde a lo que los líderes políticos del período caracterizaron como cambio de época. Apuntemos en esta instancia la tercera conclusión: el diseño de nuevas imágenes comunes parece haberse pergeñado en las propuestas estudiadas con base en un nacionalismo popular que buscó ensanchar el concepto de nación a la región y recuperar así la idea de patria grande, que dio paulatinamente espesor a una retórica latente desde aquella primera foto en la que se lo podía ver a Néstor Kirchner ordenando bajar los cuadros de los represores Jorge Rafael Videla y Reynaldo Bignone en el Colegio Militar, y que, con sus bemoles, se definió en favor de una democratización del acceso a las formas.

Como es esperable esta investigación no cierra ni agota el tema. En un reservorio de actos posibles, surgen líneas de investigación hacia el futuro de este pasado y hacia el pasado de este pasado: la comparación más exhaustiva del kirchnerismo en su fase estética y cultural con los tres gobiernos peronistas anteriores y el contraste del período analizado con lo ocurrido en el siguiente. La tracción móvil entre supresión, continuidad, achicamiento y reorientación que parece haber caracterizado el rumbo de las políticas artísticas y culturales de la alianza Cambiemos en los cuatro años posteriores al período examinado probablemente será objeto de análisis capaces de resignar presupuestos y cristalizaciones para comprender esas propuestas en sus magnitudes menos evidentes. Lo mismo cabe para la apertura del tiempo que se ha abierto en la vida política argentina a partir del triunfo en las últimas elecciones de un frente en el que convergen muchos de los actores que llevaron adelante las iniciativas que nos hemos ocupado de revisar en este escrito. 
Una vez más, la pregunta por el arte y por sus potencialidades para operar en planos de identificación no cuantificables pero decisivos tiene una oportunidad para ocupar el centro de la escena. Si, aunque más no sea, hemos contribuido aquí a la comprensión de que las imágenes, las dimensiones espacio temporales, las operaciones formales y metafóricas y los contornos que adopta la simbolización son aspectos ineludibles para comprender el presente, si hemos apenas colaborado en generar un paraje desde el cual seguir preguntándonos por el rol que cumple el arte en la disposición de sentidos capaces de trastocar las pautas que organizan la vida común, si lo hemos logrado al menos parcialmente, la tarea está cumplida. 
REFERENCIAS 


\section{BIBLIOGRAFÍA}

Abramowski, A. e Igarzábal, B. (2011). Uso y apropiación de las producciones de Canal Encuentro en las escuelas bonaerenses. Cuadernos de investigación, (1), 39-47.

Acha, J. (1979). Arte y sociedad: Latinoamérica. Sistema de producción. México: Fondo de Cultura Económica.

Alabarces, P. (30 de mayo de 2010). El Estado nación no estaba tan muerto. En Miradas al Sur, p. 14.

Alonso, R. (2000). La ciudad-escenario: itinerarios de la performance pública y la intervención urbana. En Actas de las Jornadas de Teoría y Crítica, La Habana, Cuba.

Amorebieta y Vera, M.L. (2019). "200 años es una sola vez» Los discursos y las prácticas conmemorativas de los gobiernos de Argentina, Ecuador, Bolivia y Venezuela durante sus bicentenarios de "independencia» (2009-2011) (Tesis de doctorado). Facultad de Humanidades y Ciencias de la Educación de la Universidad Nacional de La Plata.

Anderson, B. (1993). Comunidades imaginadas. Sobre el origen y la difusión de nacionalismo. México: Fondo de Cultura Económica.

Andrade, G.; Carnevale, G. y Massone, M. (septiembre de 2016). El saber histórico en materiales escolares digitales: una propuesta de investigación y docencia. Ponencia presentada en las XVI Jornadas Nacionales y V Internacionales de Enseñanza de la Historia. Facultad de Humanidades, Universidad Nacional de Mar del Plata, Mar del Plata, Argentina.

Aprea, G. (2012). Cine histórico argentino contemporáneo: una nueva manera de relacionarse con el pasado. Ponencia presentada en el III Congreso Internacional de la Asociación Argentina de Estudios de Cine y Audiovisual. Recuperado de: http://www.asaeca.org/aactas/aprea gustavo - ponencia.pdf

Aprea, G. (2014). El pasado nacional desde el presente: miradas que construyen identidades desde la crisis del 2001 al Bicentenario. Recuperado de http://www.asaeca.org/aactas/aprea.pdf

Aumont, J. (1992). La imagen. Barcelona, España: Ediciones Paidós.

Bajtin, M (1979). Estética de la creación verbal. Buenos Aires, Argentina: Siglo Veintiuno.

Batlle, D. (2011). La espada del santo. Recuperado de https://www.otroscines.com/nota?idnota $=5329$

Bavala, M.F. y Suárez, C.A. (2016). Desarrollo de Políticas Públicas Culturales y Participación Ciudadana durante el Kirchnerismo. Revista Debate Público. Reflexión de Trabajo Social, 6 (11), 87-93. 
Becerra, M. y Mastrini G. (2016). Políticas de medios del kirchnerismo. Análisis de las políticas de comunicación2003-2015 y agenda pendiente. Fundación Friedrich Ebert (13). Recuperado de https://library.fes.de/pdf-files/bueros/argentinien/12821.pdf

Belinche, D. (1993). El tango como metáfora de la ilusion perdida. BOA, 15 (10). 114117.

Belinche, D. (2011). Arte, poética y educación. La Plata, Argentina: Secretaría de Publicaciones y Posgrado, Facultad de Bellas Artes de la Universidad Nacional de La Plata.

Belinche, D. (2017). Diez formas de arruinar una clase. La Plata, Argentina: Papel Cosido.

Belinche Montequín, M., Pilaría, S. y Ward, I. (2016). Una excursión a los orígenes de la escuela. Historia y educación en una propuesta audiovisual. Octante, (1), 34-41. Recuperado de http://papelcosido.fba.unlp.edu.ar/ojs/index.php/octante/article/view/163

Belinsky, J. (2007). Lo imaginario: un estudio. Buenos Aires: Nueva Visión.

Benjamin, W. (1982 [1940]). Tesis de Filosofía de la Historia. En Benjamín, Walter: Discursos Interrumpidos I. Madrid, España: Taurus, 1982. pp.175-191.

Benjamin, W. (1987). La obra de arte en la época de su reproductibilidad técnica. En Discusos interrumpidos 1. Madrid, España: Taurus.

Bernardo, N. (2015). Paka Paka, una cartografía posible sobre la construcción de subjetividades y las tecnologías. Oficios Terrestres (33), 121-131.

Bisso, A., Kahan, E. y Sessa, L. (2014), Formas políticas de celebrar y conmemorar el pasado (1930-1943). La Plata, Argentina: Ceraunia.

Biblioteca Nacional y Piglia, R., (2012). Escenas de la novela argentina. Clases abiertas [Programa televisivo]. Recuperado de https://www.youtube.com/watch?v=fpTjISG4Pso\&list=PLTtUBvUqdeJTRiNF5Olv4N1 4SIwJULA0Z\&index $=7$

Biord Castillo, P.R. (1996). Del signo al símbolo. Anthropos, (32-33), 21-44

Bohoslavsky, E. (2011). ¿Qué es América Latina? El nombre, la cosa y las complicaciones para hablar de ellos. Recuperado de https://www.ungs.edu.ar/cm/uploaded_files/file/publicaciones/trama/pdf/bohosla vsky.pdf

Borges, J. L. (1980). Arte poética. Seis conferencias. Barcelona, España: Editorial Crítica. 
Braudel, F. (1979). La larga duración en la historia y las ciencias sociales. Madrid: Alianza.

Buletti, S. (2017). Los materiales audiovisuales de canal Encuentro en las clases de Historia: una aproximación desde la práctica docente. Ponencia presentada en las XVI Jornadas Interescuelas/Departamentos de Historia. Facultad Humanidades de la Universidad Nacional de Mar del Plata, Mar del Plata, Argentina.

Campi, Alessandro. (2006). Nación. Léxico de política. Buenos Aires: Nueva Visión.

Casa Rosada Presidencia (16 de julio de 2015). Acto de inauguración de la quinta edición de Tecnópolis: Palabras de la Presidenta de la Nación. Disponible en https://www.casarosada.gob.ar/informacion/archivo/28888-acto-de-inauguracionde-la-quinta-edicion-de-tecnopolis-palabras-de-la-presidenta-de-la-nacion

Castrillón Ramírez, D. (2017). La Asombrosa excursión de Zamba como recurso pedagógico para la escuela primaria (Tesis de Maestría). Facultad de Diseño y Comunicación de la Universidad de Palermo, Buenos Aires, Argentina.

Castro, M.J. (2018). Mirando PakaPaka: una exploración analítica sobre la producción de sentidos políticos-culturales de la niñez en «La Asombrosa Excursión de Zamba». Ponencia presentada en el XI Seminario Internacional Políticas de la Memoria. Memorias subalternas, memorias rebeldes. Centro Cultural Haroldo Conti, Espacio Memoria y Derechos Humanos (Ex ESMA), Buenos Aires, Argentina.

Castro, M. J. y Pardo, M. V., (2015). ¿'Por qué, cuándo y para qué? Nuevos paradigmas en televisión educativa: La asombrosa excursión de Zamba (Televisión Pública). Recuperado de http://sociales.unq.edu.ar/wpcontent/uploads/byt2015/ponencias/eje08/CASTRO_ Maria_JoseyPARDO_MariaDeLaVictoria_PONENCIA.pdf

Casullo, N. ; Forster, R. y Kaufman, A. (2009). Itinerarios de la modernidad: corrientes del pensamiento y tradiciones intelectuales desde la ilustración hasta la posmodernidad. Buenos Aires, Argentia: Eudeba, 2009.

Cattaruzza, A. (2007). Los usos del pasado. La historia y la política argentina en discusión, 1910-1945. Buenos Aires: Sudamericana.

Chartier, R. (1992). El mundo como representación. Historia cultural entre práctica y representación. Barcelona: Gedisa.

Chateau, J. (1976). Las fuentes de lo imaginario. Ciudad de México, México: Fondo de la cultura económica.

Ciafardo, M. (2015). Entrevista a Liliana Porter. Colección Breviarios. Arte y Opinión (8). Recuperado

de http://papelcosido.fba.unlp.edu.ar/pdf/colecciones/breviarios/Breviarios-8.pdf 
Ciafardo, M. (2016). Las imágenes visuales latinoamericanas. El derecho a la contemporaneidad. Octante, (1), 23-33.

Ciafardo, M. (2019). La enseñanza del lenguaje visual. Bases para la construcción de una propuesta alternativa. La Plata, Argentina: Universidad Nacional de La Plata. Facultad de Bellas Artes.

Cinícola, P. (2013). La Entrevista en la Televisión Pública. Los casos de los programas Encuentro en el Estudio e Historias Debidas. Revista Question, (37). Recuperado de http://perio.unlp.edu.ar/ojs/index.php/question/article/viewFile/1764/1483

Colombres, A. ([1987]2007). Sobre la cultura y el arte popular. Buenos Aires, Argentina: Ediciones del Sol.

Colombres, A. (2005). Teoría transcultural del arte: hacia un pensamiento visual. Buenos Aires, Argentina: Del Sol.

Corte, M. (2016). Reflexiones en torno al propósito educativo de Canal Encuentro. Question/Cuestión, $1 \quad$ (51), 360-375. Recuperado de https://perio.unlp.edu.ar/ojs/index.php/question/article/view/3403

Cottet, C.; Gómez, J.M. y laccarino, M. (2012). Detrás de una imagen cinematográfica. Recuperado http://blogs.ffyh.unc.edu.ar/fotografiacinematografica/2012/06/10/755/

Crivelli, S. (2015). Las aventuras de Zamba. Apuntes sobre la comunicación audiovisual en un canal infantil del Ministerio de Educación argentino. II Congreso Comunicación/Ciencias Sociales desde América Latina, Facultad de Periodismo y Comunicación Social de la Universidad Nacional de La Plata. Recuperado de https://perio.unlp.edu.ar/ojs/index.php/actas/article/view/2872.

Clark, T. (2000). Arte y Propaganda en el siglo XX. Madrid, España: Ediciones Akal.

Debray, R. (1994). Vida y muerte de la imagen. Historia de la mirada en Occidente. Barcelona, España: Paidós.

De Sousa Santos, B. (2009). Una epistemología del Sur. La reinvención del conocimiento y la emancipación social. México: CLACSO y Siglo XXI.

Didi-Huberman, Georges (2006). Ante el tiempo. Historia del arte y anacronismo de las imágenes. Buenos Aires: Adriana Hidalgo Editora.

Didi-Huberman, G. (2008). Cuando las imágenes toman posición. Madrid, España: Antonio Machado Libros.

Didi Huberman, G. (2009). La imagen superviviente. Historia del arte y tiempo de los fantasmas según Aby Warburg. Madrid, España: Abada Editores. 
Dussel, I. (2006). Algunas reflexiones sobre el lugar de las imágenes en el ámbito escolar. En Dussel, I. y Gutiérrez, D. (Coords.), Educar la mirada. Políticas y pedagogías de la imagen. Buenos Aires, Argentina: Manantial /FLACSO / OSDE.

Durán, L., Litvinoff, L., Roldán, D. y Tomassoni, P. (2016). Canal Encuentro y el relato de la hisotoria reciente. Ponencia presentada en IX Seminario Internacional Políticas de la Memoria. Centro Cultural de la Memoria Haroldo Conti, Buenos Aires, Argentina.

Elías, Norbert. (1997). Os alemães. Rio de Janeiro: Jorge Zahar Editores.

Feinmann, J.P. (2008). La filosofía y el barro de la historia. Buenos Aires, Argentina: Planeta.

Fernández, P.E. (2014). Gestión de marca e identidad en la televisión pública. Análisis de Canal Encuentro, Argentina. Cuadernos.info, 34, 81-92. doi: 10.7764/cdi.34.56

Fernández Presa, M. E. (2017). iA la carga mis valientes! Historia, identidad (es) y Estado nacional en la Argentina después de la crisis de 2001 (Tesis de maestría). Universidad Federal de Integración Latinoamericana, Foz do Iguazú, Brasil.

Fernández, C. I. (2020). Estado y políticas culturales en Argentina. Un análisis comparativo entre el Kirchnerismo y la Alianza Cambiemos (2007-2017). Sociohistórica, (45), doi: https://doi.org/10.24215/18521606e102

Finocchio, S. y Massone, M. (2012). Una propuesta de enseñanza de la historia en la cultura digital. Entrevista a Gisela Andrade y Alejandra Rodríguez sobre Múltiples voces del Bicentenario. Clio y Asociados. La Historia Enseñada, (16), 237-243, Universidad Nacional de la Plata.

Fiorucci, F. (2008). Reflexiones sobre la gestión cultural bajo el Peronismo. Nuevo Mundo Mundos Nuevos. Disponible en http://journals.openedition.org/nuevomundo/24372

Fischerman, D. (2013). Efecto Beethoven: complejidad y valor en la música de tradición popular. Buenos Aires, Argentina: Paidós.

Flores Martos, J. (2001). Un continente de carnaval: etnografía crítica de carnavales americanos. Recuperado de https://www.google.com/search?q=flores+martos+carnaval\&oq=flores+martos+car naval\&aqs=chrome..69i57j33.8324j0j9\&sourceid=chrome\&ie=UTF-8

Franco, Mariana y Levín, Florencia (comps.) (2007). Historia reciente. Perspectivas y desafíos para un campo en construcción. Buenos Aires: Paidós.

Freud, S. (1900). Obras Completas. Tomos IV y V. Buenos Aires, Argentina: Amorrortu Editores. 
Fundación Cisneros (2013). Liliana Porter en conversación con Inés Katzenstein. New York, Estados Unidos: Fundación Cisneros.

Gadamer, H.G. (1991). La actualidad de lo bello. Barcelona, España: Ediciones Paidós.

García, S. y Belén, P. (Comps.). (2014). La representación de lo indecible en el arte popular latinoamericano. La Plata, Argentina: Facultad de Bellas Artes, Universidad Nacional de La Plata.

Gastaldi, S. (agosto de 2015). La construcción de la memoria en cuentos animados: un análisis de "La asombrosa excursión de Zamba». Ponencia presentada en el VIII Seminario Regional (Cono Sur), Asociación Latinoamericana de los Investigadores de la Comunicación (ALAIC), Córdoba, Argentina.

Gené, M. (2005). Un mundo feliz. Imágenes de los trabajadores en el primer peronismo 1946-1955. Buenos Aires, Argentina: FCE-Universidad San Andrés.

Giarracca, N. (2011). El bicentenario: miradas sobre la argentina. En: Norma Giarracca (comp.), Bicentenarios (otros), transiciones y resistencias (pp. 143-160). Buenos Aires: Una ventana ediciones.

Giunta, A. (2001). Vanguardia, internacionalismo y política. Arte argentino en los años sesenta. Buenos Aires, Argentina: Paidós.

Gomes, G. (2016). Valoraciones y prejuicios sobre La asombrosa excursión de Zamba. Clío \& Asociados (23), 37-50. En Memoria Académica. Recuperado de http://www.memoria.fahce.unlp.edu.ar/art revistas/pr.8150/pr.8150.pdf

González, J. (2014). Intelectuales y política en el kirchnerismo: Un estudio sobre Carta Abierta (2008-2012) (Tesis de Licenciatura en Sociología). Disponible en http://www.memoria.fahce.unlp.edu.ar/tesis/te.979/te.979.pdf

González, H y Rinesi, E. (Coomps.). (2016). Decorados: apuntes para una historia social del cine argentino. Buenos Aires, Argentina: Editorial Caterva.

González, M. (2015). Configurar el relato: estética y montaje de imágenes performáticas en los festejos del bicentenario nacional. Disponible en http://www.iaa.fadu.uba.ar/ojs/index.php/anales/article/view/174

Grimson, A. (2007). Pasiones nacionales. Política y cultura en Brasil y Argentina. Buenos Aires, Argentina: Edhasa.

Grimson, A. (2011). Los límites de la cultura. Críticas de las teorías de la identidad. Buenos Aires, Argentina: Siglo Veintiuno.

Guber, R. (2001). ¿Por qué Malvinas? De la causa nacional a la guerra absurda. Buenos Aires, Argentina: Fondo de la Cultura Económica. 
Gullino, P. F. (septiembre de 2013). "A la carga mis valientes». Representaciones mediáticas educativas a partir de un caso de la historia reciente: la guerra de Malvinas. Ponencia presentada en las XVII Jornadas Nacionales de Investigación en Comunicación. Universidad Nacional de General Sarmiento, Buenos Aires, Argentina.

Gutiérrez Celano, Milena (agosto de 2019). Festejos Bicentenarios y nuevas tecnologías: continuidades en las representaciones de Nación a través del videomapping (2010-2016). Ponencia presentada en las XIII Jornadas de Sociología. Facultad de Ciencias Sociales, Universidad de Buenos Aires, Buenos Aires, Argentina.

Hakim Fernández, N. (2014). Los límites de la cultura y de las teorías de la identidad: una entrevista a Alejandro Grimson. Revista De Antropología Social, 23, 263-273. Recuperado de https://revistas.ucm.es/index.php/RASO/article/view/46897.

Halbwachs, M. (1994). Le cadres sociaux de la memoire. París, Francia: Albin Michel. Halbwachs, M. (2011). La memoria colectiva. Buenos Aires, Argentina: Miño y Dávila. Iribarren, M. (Coord.) (2017). La imagen argentina. Episodios cinematográficos de la historia nacional. Buenos Aires, Argentina: Fundación CICCUS.

Jelín, E. (2002). Los trabajos de la memoria. Madrid, España: Siglo Veintiuno

Jelin, E. (2002). Las conmemoraciones: las disputas en las fechas infelices. Madrid, España: Siglo Veintiuno.

Jiménez, J. (1986). Imágenes del hombre. Fundamentos de estética. Madrid, España: Editorial Tecnos.

Kriger,C. (2009). Cine y Peronismo. El estado en escena. Buenos Aires, Argentina: Siglo XXI.

Lacarrieu, M., y Cerdeira, M. (2016). Institucionalidad y políticas culturales en Argentina. Límites y tensiones de los paradigmas de democratización y democracia cultural. Políticas Culturales Revista, (9), 10-33.

Laclau, E. (2005). La razón populista. Buenos Aires: Fondo de Cultura Económica.

Larregle, E. (2012). Bajan las luces, empieza la música. Arkadin, 6 (4), 66-72.

Leonardi, Y. A. (2012). Experiencias artístico-educativas para los obreros durante el primer peronismo. Nuevo Mundo Mundos Nuevos. Disponible en http://journals.openedition.org/ nuevomundo/63699

Ligeti, G. (1970). De la forme musicale. VH 101 Printemps, (1), 77-88.

Linare, C. y Cuesta, V. (2015). Incursionando en el asombroso mundo de Zamba. El Toldo de Astier, 6 (10), 92-100. Recuperado de http://www.memoria.fahce.unlp.edu.ar/art_revistas/pr.6528/pr.6528.pdf 
Lindenboim, F. M. (2013). Radio y peronismo: la construcción de una narración nacional. Ponencia presentada en las XIV Jornadas Interescuelas. Departamentos de Historia. Facultad de Filosofía y Letras de la Universidad Nacional de Cuyo, Mendoza, Argentina.

Lopez, V. (2011). Ciencia en Encuentro, narrativas para la TV digital. Question, 1(29). Recuperado de https://perio.unlp.edu.ar/ojs/index.php/question/article/view/566

Lorenz, F. (2006). Las guerras por Malvinas. Buenos Aires: Edhasa.

Madonessi, M. (2008). Historia, memoria y política. Entrevista con Enzo Traverso. Disponible en http://www.scielo.org.mx/scielo.php?script=sci arttext\&pid=S1870$\underline{00632008000100010}$

Margulis, P. (2017). En transición: el documental argentino hacia el retorno democrático. En Iribarren, M. (Coomp.). La imagen argentina: episodios cinematográficos de la historia nacional (pp. 177-186). Buenos Aires, Argentina: Fundación CICCUS.

Mariano, M. ; Endere, M. (2017). Carnavales y patrimonios: diálogos sobre identidades y espacios de participación. Memorias: Revista Digital de Arqueología e Historia desde el Caribe (mayo-agosto), 10-41.

Martínez Alonso, G. (2012). La asombrosa excursión de Zamba: la parodia como estrategia educativa. Recuperado de https://es.scribd.com/doc/113568122/LaAsombrosa-Excursion-de-Zamba-la-parodia-como-estrategia-educativa

Murolo, N. L. (2013). La asombrosa excursión de Zamba. Un viaje animado por la historia en la televisión pública argentina. Chasqui Revista Latinoamericana de Comunicación, (122), 89-95.

Molinaro, N. (2013). Los pueblos originarios en el Bicentenario argentino (2010): ¿Hacia un reconocimiento nacional?. Recuperado de http://alhim.revues.org/4342

Nagore María (2004). "El análisis musical, entre el formalismo y la hermenéutica». En Músicas al Sur $N^{\circ} 1$. Madrid: Universidad Complutense.

Nora, P. (2009). Pierre Nora en Les Lieux de Mémoire. Santiago, Chile: LOM

Oporto, M. (2011). De Moreno a Perón. Pensamiento argentino de la unidad latinoamericana. Argentina, Buenos Aires: Planeta.

Ortemberg, P. (2014). Tecnología, narración y espectáculo en el corazón de la fiesta patria. Políticas de la memoria, 14 (14), 169-180. Recuperado de http://ojs.politicasdelamemoria.cedinci.org/index.php/PM/article/view/296 
Perochena, C. (2018). Tiempo, historia y política. Una reflexión comparativa sobre las conmemoraciones bicentenarias en México y Argentina. Recuperado de https://www.historiadahistoriografia.com.br/revista/article/view/1280

Piglia, R. ([1986] 2015). Formas breves. Barcelona, España: Anagrama.

Piglia, R. (2016). Las tres vanguardias. Buenos Aires, Argentina: Eterna Cadencia.

Piglia, R. (2019). Teoría de la prosa. Ciudad Autónoma de Buenos Aires: Eterna Cadencia Editora.

Puiggrós, A. (2012). Qué pasó en la educación argentina: Breve historia desde la conquista hasta el presente. Buenos Aires, Argentina: Galerna.

Rabotnikof, N. (2009). Política y tiempo: pensar la conmemoración. Sociohistórica, 26, 179-212. Recuperado de https://www.sociohistorica.fahce.unlp.edu.ar/article/view/n26a06

Rancière, J. (2005). Sobre políticas estéticas. Barcelona, España: Museud'Art Contemporani de Barcelona.

Retamozo,M. (2012). Intelectuales, kirchnerismo y política. Una aproximación a los colectivos de intelectuales en Argentina. Nuevo Mundo Mundos Nuevos. Disponible en http://journals.openedition.org/ nuevomundo/64250

Richard, N. (2007). Fracturas de la memoria. Arte y pensamiento crítico. Buenos Aires, Argentina: Siglo XXI.

Ricoeur, P. (2004). La memoria, la historia, el olvido. Buenos Aires, Argentina: Fondo de Cultura Económica.

Rojas, M. (2013). El asombroso mundo de Zamba. Revista Planetario. Recuperado de https://www.revistaplanetario.com.ar/news/view/el-asombroso-mundo-de-zamba

Rosaldo, Renato. (1992). Reimaginando las comunidades nacionales. En: Valenzuela Arce, Jose (Coord.). Decadencia y auge de las identidades: cultura nacional, identidad cultural y modernización. Tijuana, México: El Colegio de la Frontera Norte.

Rossi Delaney, S. (2015). Patriotismo de baja estofa. Reseña de Belgrano, la película, de Sebastián Pivotto, con Pablo Rago y Valeria Bertuccelli. Recuperado de https://razonyrevolucion.org/patriotismo-de-baja-estofa-resena-de-belgrano-lapelicula-de-sebastian-pivotto-con-pablo-rago-y-valeria-bertuccelli/

Russo, Eduardo A. (1998). Diccionario de Cine. Buenos Aires, Argentina: Paidós. 
Russo, E. (2017). La pregunta por un cine nacional: utopía, crítica y heterotopía. En Iribarren, M. (Coomp.). La imagen argentina: episodios cinematográficos de la historia nacional (pp. 177-186). Buenos Aires, Argentina: Fundación CICCUS.

Salem, G. (2012). La construcción de la identidad visual de Canal Encuentro. Análisis del diseño institucional televisivo del primer canal argentino educativo y público (2007-2011), (Tesis de grado). Facultad de Arquitectura, Diseño y Urbanismo de la Universidad de Buenos Aires, Buenos Aires, Argentina.

Sánchez Porfido, E. y Gentile, L. (septiembre de 2013). Mapping en la Ciudad de La Plata: Colectivo Bazaar. Ponencia presentada en las IX Jornadas Nacionales de Investigación en Arte en Argentina. Facultad de Bellas Artes de la Universidad Nacional de La Plata, La Plata, Argentina.

Sarmiento, G. Políticas visuales de la memoria en Argentina en el período kirchnerista (2003-2015). Trabajo presentado en The power of memory: perspectives from Latin America. University of Tokyo LAINAC, Tokyo, Japón. Disponible en https://www.academia.edu/26372089/Politicas visuales de la memoria_en Arge ntina en el per\%C3\%ADodo kirchnerista 2003-2015

Sartre, J. P. [1940] (1976). Lo imaginario. Psicología Fenomenológica De La Imaginación. Recuperado de

http://200.95.144.138.static.cableonline.com.mx/famtz/smr/index_archivos/cursos lo imaginario lectura.pdf

Scarcella, D. (2013). Cine del «bicentenario» y redefiniciones identitarias: la inclusión de un otro en los relatos de la historia argentina. Ponencia presentada en las XIV Jornadas Interescuelas/Departamentos de Historia. Departamento de Historia de la Facultad de Filosofía y Letras. Universidad Nacional de Cuyo, Mendoza, Argentina.

Shiota, C. (2017). During Sleep. Recuperado de https://www.chiharushiota.com/during-sleep-78

Segura, M. S., y Prato, V. (2018). Presentación. En Estado, sociedad civil y políticas culturales. Rupturas y continuidades en Argentina entre 2003 y 2017 (pp. 13-20). Buenos Aires, Argentina: RGC Ediciones.

Siddig, E. (30 de mayo de 2010). Carrozas de fuego. En Miradas al Sur, pp. 1-4.

Smerling, T. (2015). La otra pantalla: educación, cultura y televisión. 2005-2015, una década de Canal Encuentro, Pakapaka y las nuevas señales educativas. Buenos Aires, Argentina: Ministerio de Educación de la Nación.

Sontag, S. [1970] (1996). Contra la interpretación. Ciudad Autónoma de Buenos Aires, Argentina: Alfaguara. 
Sotelo, M. (2011). Yo estuve ahí. Reflexiones sobre los significados de la conmemoración de los significados del Bicentenario en Argentina. Recuperado de https://www.aacademica.org/000-093/165.pdf.

Stornini, J. (2015). Fervores patrióticos: Monumentos y conmemoraciones revisionistas en la historia reciente. En A. Eujanian, R. Pasolini, y M. E. Spinelli (Coords.), Episodios de la cultura histórica argentina: Celebraciones, imágenes y representaciones del pasado, siglo XIX y XX (pp. 85-104). Buenos Aires: Biblos.

Suriano, J. (2015). El Bicentenario de la Revolución de Mayo y los discursos públicos sobre la historia. TAREA, 2, 154-172.

Tal, T. (2013). El Kruce de los Andes. La imagen de San Martín y el discurso oficial. Ponencia presentada en las XIV Jornadas Interescuelas, Departamentos de Historia. Departamento de Historia de la Facultad de Filosofía y Letras. Universidad Nacional de Cuyo, Mendoza, Argentina.

Taylor, D. (2012). Performance. Ciudad Autónoma de Buenos Aires, Argentina: Asunto Impreso.

Tejeiro, V. (2017). Disputas y encuentros entre peronismo y arte abstracto. Caiana, (10), 146-159.

Tenaglia, A. (2013). Entrevista a Sebastián Mignona. Director de Zamba. Recuperado de https://aldanatenaglia.webnode.com.ar/news/entrevista-a-sebastian-mignognadirector-de-zamba/

Tobeña, V. (julio de 2015). Una excursión a la Guerra de Malvinas de la mano de Zamba. La "Cuestión Malvinas» en clave infantil. Ponencia presentada en las XI Jornadas de Sociología, Universidad de Buenos Aires, Buenos Aires, Argentina.

Todorov, T. (1970). Teoría de la literatura de los formalistas rusos. Jakobson, Tinianov, Eichenbaum, Brik, Shklovski, Vinogradov, Tomaschevski, Propp. Madris, España: Siglo veintiuno.

Todorov, T. (1991). Teorías del símbolo. Caracas, Venezuela: Monte Ávila Editores.

Traverso, E. (2007). El pasado, instrucciones de uso. Historia, memoria, política. Madrid, España: Marcial Pons.

Trotta, L. y Santucci, P. (2010). Resela del Ciclo Escuelas Argentinas emitido por Canal Encuentro. En Archivos de la ciencia 4(4).

Varela, G. (2007). La fiesta y el sótano. En Korn, G. (Coomp.), El peronismo clásico (1945-1955). Descamisados, gorilas y contreras. Buenos Aires, Argentina: Paradiso. 
Wainsztok, C., Durán, M., López Cardona, D., Imen, P. y Ouvina, H. (2013). Simón Rodríguez y las pedagogías emancipadoras en Nuestra América. Buenos Aires, Argentina: C. C. de la Cooperación.

Warburg, A. ([1920] 2008). El renacimiento del paganismo. Madrid, España: Alianza.

Yepes, E. (2008). América latina: un concepto difuso y en constante revisión. Recuperado de https://es.scribd.com/doc/211749094/Ensayo-America-Latina

Zamorano, M. (2016). La transformación de las políticas culturales durante la primera década kirchnerista. Entre la hegemonía y la diversidad. Aposta, Revista de Ciencias Sociales, (70), 53-83.

Zátonyi, M. (2007). Arte y creación. Los caminos de la estética. Buenos Aires, Argentina: Capital intelectual.

\section{MATERIALES ANALIZADOS}

Canal Encuentro (17 de abril de 2016 a). Filosofía aquí y ahora. El 30 y la metafísica del tango [Archivo de video]. Disponible en https://www.youtube.com/watch?v=u7Rb6ZErOOg

Canal Encuentro (24 de marzo de 2016 b). Filosofía aquí y ahora. Los posmodernos [Archivo de video]. Disponible en https://youtu.be/HtJOmHZ5XJQ

Canal Encuentro (24 de marzo de 2016 c). Filosofía aquí y ahora. Heidegger y el nazismo [Archivo de video]. Disponible en https://www.youtube.com/watch?v=cxcigPCToHs\&t=1s

Ipiña,L. (Director), Bacin, M. (Productora) \& Villamagna, G. (Productor). (2012). Revolución: el cruce de los Andes [Película]. Argentina: TV Pública, Canal Encuentro, INCAA.

La Doble A (9 de junio de 2010). Mapping sobre el Cabildo, Festejos por el Bicentenario de la Revolución de Mayo [Archivo de video]. Disponible en https://www.youtube.com/watch?v=eUxurpcHURs

Mignogna, S. (Director), (2010a). La asombrosa excursión de Zamba al Cabildo [Serie televisiva]. Recuperado de http://www.pakapaka.gob.ar/videos/50119

Mignogna, S. (Director), (2010b). La asombrosa excursión de Zamba. Se decide el Cabildo abierto [Serie televisiva]. Recuperado de http://www.pakapaka.gob.ar/videos/50120 
Mignogna, S. (Director), (2010c). La asombrosa excursión de Zamba. El pueblo pide Cabildo abierto [Serie televisiva]. Recuperado de http://www.pakapaka.gob.ar/videos/50121

Mignogna, S. (Director), (2010d). La asombrosa excursión de Zamba. 25 de Mayo de 1810 [Serie televisiva]. Recuperado de http://www.pakapaka.gob.ar/videos/50122

Mignogna, S. (Director), (2011a). La asombrosa excursión de Zamba en la casa de Sarmiento [Serie televisiva]. Recuperado de http://www.pakapaka.gob.ar/videos/50636

Mignogna, S. (Director), (2011b). La asombrosa excursión de Zamba en Yapeyú [Serie televisiva]. Recuperado http://www.pakapaka.gob.ar/videos/50638

Mignogna, S. (Director), (2011c). La asombrosa excursión de Zamba en la Vuelta de Obligado [Serie televisiva]. Recuperado de http://www.pakapaka.gob.ar/videos/100200

Mignogna, S. (Director), (2012a). La asombrosa excursión de Zamba en la Casa Rosada [Serie televisiva]. Recuperado de http://www.pakapaka.gob.ar/videos/104628

Mignogna, S. (Director), (2012b). La asombrosa excursión de Zamba en las Islas Malvinas [Serie televisiva]. Recuperado de http://www.pakapaka.gob.ar/videos/50636

Mignogna, S. (Director), (2015). La asombrosa clase de Zamba sobre la memoria [Serie televisiva]. Recuperado de https://www.youtube.com/watch?v=KsEavsbrimw

Pivotto, S. (Director) \& Campanella, J.J. (Productor). (2010). Belgrano. [Película]. Argentina: TV Pública, Canal Encuentro, INCAA.

Televisión Pública (2 de junio de 2010). Especial Festejo del Bicentenario (parte 13 de 20) [Archivo de video]. Disponible en https://www.youtube.com/watch?v=QaVxlimu0oo

Televisión Pública (2 de junio de 2010). Especial Festejo del Bicentenario (parte 14 de 20) [Archivo de video]. Disponible en https://www.youtube.com/watch?v=raAYjKV421w\&t=339s

Televisión Pública ( 2 de junio de 2010). Especial Festejo del Bicentenario (parte 15 de 20) [Archivo de video]. Disponible en https://www.youtube.com/watch?v=ncbO2xpPI5w\&t=439s

Televisión Pública (2 de junio de 2010). Especial Festejo del Bicentenario (parte 16 de 20) [Archivo de video]. Disponible en https://www.youtube.com/watch?v=meolFe7iP5A 
Televisión Pública (2 de junio de 2010). Especial Festejo del Bicentenario (parte 17 de 20) [Archivo de video]. Disponible en https://www.youtube.com/watch?v=pRDI2irfqxI

Televisión Pública (21 de octubre de 2010). Síntesis de los cinco días de fiesta [Archivo de video]. Disponible en https://www.youtube.com/watch?v=hUDzVpzFXCQ\&t=5847s

Televisión Pública Argentina (01 de septiembre de 2012 a). Escenas de la novela argentina [archivo de video]. Disponible en https://www.youtube.com/watch?v=mKOENCrDB0Q\&list=PLM2azdA0sTU-710YgcyWM-SSE8cSdRrH\&index=1

Televisión Pública Argentina (08 de septiembre de 2012 b). Escenas de la novela argentina [archivo de video]. Disponible en https://www.youtube.com/watch?v=mMcBd105HVI\&list=PLM2azdA0sTU-7-

1oYgcyWM-SSE8cSdRrH\&index $=4$

Televisión Pública Argentina (15 de septiembre de 2012 a). Escenas de la novela argentina [archivo de video]. Disponible en https://www.youtube.com/watch?v=fpTjISG4Pso\&list=PLM2azdA0sTU-71oYgcyWM-SSE8cSdRrH\&index $=7$

Televisión Pública Argentina (22 de septiembre de 2012 a). Escenas de la novela argentina [archivo de video]. Disponible en https://www.youtube.com/watch?v=7OYB-SovNgg\&list=PLM2azdA0sTU-71oYgcyWM-SSE8cSdRrH\&index $=10$

Televisión Pública Argentina (07 de septiembre de 2013 a). Borges por Piglia [archivo de video]. Disponible en https://www.youtube.com/watch?v=im kMvZQlv8

Televisión Pública Argentina (16 de septiembre de 2013 b). Borges por Piglia [archivo de video]. Disponible en https://www.youtube.com/watch?v=kZX gQLMxEM\&t=1259s

Televisión Pública Argentina (23 de septiembre de 2013 c). Borges por Piglia [archivo de video]. Disponible en https://www.youtube.com/watch?v=_BxOE3bO6SM

Televisión Pública Argentina (28 de septiembre de 2013). Borges por Piglia [archivo de video]. Disponible en https://youtu.be/5svf4mzbeTc

Televisión Pública Argentina (18 de junio de 2011). Belgrano, así se hizo [archivo de video]. Disponible en https://www.youtube.com/watch?v=WpWz yfvOAk 
